Issued by Sandia National Laboratories, operated for the United States Department of Energy by Sandia Corporation.

NOTICE: This report was prepared as an account of work sponsored by an agency of the United States Government. Neither the United States Government, nor any agency thereof, nor any of their employees, nor any of their contractors, subcontractors, or their employees, make any warranty, express or implied, or assume any legal liability or responsibility for the accuracy, completeness, or usefulness of any information, apparatus, product, or process disclosed, or represent that its use would not infringe privately owned rights. Reference herein to any specific commercial product, process, or service by trade name, trademark, manufacturer, or otherwise, does not necessarily constitute or imply its endorsement, recommendation, or favoring by the United States Government, any agency thereof, or any of their contractors or subcontractors. The views and opinions expressed herein do not necessarily state or reflect those of the United States Government, any agency thereof, or any of their contractors.

Printed in the United States of America. This report has been reproduced directly from the best available copy.

\section{Available to DOE and DOE contractors from}

U.S. Department of Energy

Office of Scientific and Technical Information

P.O. Box 62

Oak Ridge, TN 37831

Telephone: (865)576-8401

Facsimile: (865)576-5728

E-Mail:_reports@adonis.osti.gov

Online ordering: http://www.doe.gov/bridge

Available to the public from

U.S. Department of Commerce

National Technical Information Service

5285 Port Royal Rd

Springfield, VA 22161

Telephone: (800)553-6847

Facsimile: (703)605-6900

E-Mail: orders@ntis.fedworld.gov

Online order: http://www.ntis.gov/ordering.htm

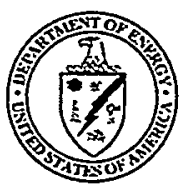




\section{DISCLAIMER}

\section{Portions of this document may be illegible in electronic image products. Images are produced from the best available original document.}


SAND2000-0400

Unlimited Release

Printed February 2000

\title{
Final State of the Strategic Petroleum Reserve (SPR) Weeks Island Mine
}

\author{
Martin A. Molecke, Editor \\ Sandia National Laboratories \\ Underground Storage Technology Department \\ Albuquerque, New Mexico 87185-0706 \\ DynMcDermott Petroleum Operations Company \\ New Orleans, Louisiana 70123 \\ PB-KBB \\ Houston, Texas 77224 \\ U. S. Department of Energy \\ Strategic Petroleum Reserve \\ New Orleans, Louisiana 70123
}

\begin{abstract}
This report documents the decommissioning and abandonment activities at the Weeks Island Strategic Petroleum Reserve (SPR) site, Iberia Parish, Louisiana, that were concluded in 1999. These activities required about six years of intense operational, engineering, geotechnical, and management support efforts, following initiation of site abandonment plans in 1994. The Weeks Island SPR mine stored about 72.5 million bbl of crude oil following oil fill in 19801982, until November 1995, when the DOE initiated oil drawdown procedures, with brine refill and oil skimming, and numerous plugging and sealing activities. About $98 \%$ of the crude oil was recovered and transferred to other SPR facilities in Louisiana and Texas; a small amount was also sold. This document summarizes recent pre- and post-closure: conditions of surface features at the site, including the sinkholes, the freeze wall, surface subsidence measurements and predictions; conditions within the SPR mine, including oil recovery, brine filling, and the Markel Wet Drift; risk assessment evaluations relevant to the decommissioning and long-term potential environmental impacts; continuing environmental monitoring activities at the site; and, an overview on the background and history of the Weeks Island SPR facility.
\end{abstract}




\section{ACKNOWLEDGEMENTS}

In memory of the U.S. Department of Energy Weeks Island Strategic Petroleum Reserve facility and mine, 1977 to 1999 . May It Rest in Peace and Geologic Stability. This report is a compilation of team efforts from the various personnel and organizations that contributed to the successful and safe decommissioning of the Weeks Island Strategic Petroleum Reserve facility over the last six years. The Department of Energy, Strategic Petroleum Reserve Project Management Office (DOE SPR PMO), under the leadership of Jerry Berndsen and W.C. Hoot Gibson, provided the day-to-day oversight for the overall program tasks; Bob Myers also provided significant inputs. Stephen J. Bauer, Brian L Ehgartner, James K. Linn, Thomas E. Hinkebein, Bruce L. Levin, Martin A. Molecke, James T. Neal (retired), Allan R. Sattler, Sandy Ballard, and Cecelia V. Williams of Sandia National Laboratories all provided significant technical input and documentation. Lisa Eldredge, Jim McHenry, Ken Mills, Gordon Payne, Thomas Westbrook, and Steve Ball of DynMcDermott Petroleum Operations Company all contributed text and other input for this report, as did Ken Stayer and Raghu Raghuraman of PB-KBB. This report was also reviewed in detail by many of the contributing writers (thanks especially to Brian Ehgartner and Jim Linn at Sandia, for serving as formal reviewers) and others at all of the mentioned organizations. Thanks to all. 


\section{TABLE OF CONTENTS}

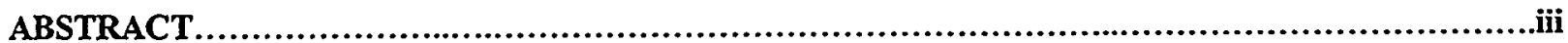

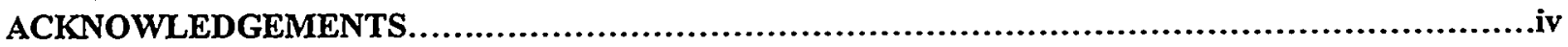

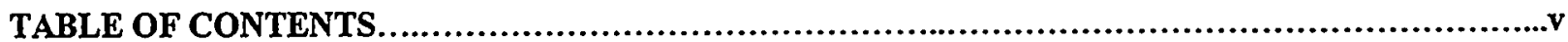

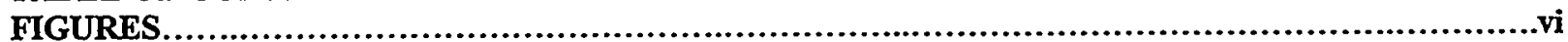

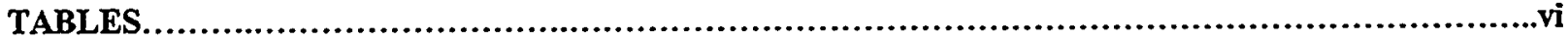

1. INTRODUCTION AND EXECUTIVE SUMMARY ..................................................................................

2. BACKGROUND OF STRATEGIC PETROLEUM RESERVE

3. SELECTION AND CONVERSION OF THE WEEKS ISLAND MINE .......................................................5

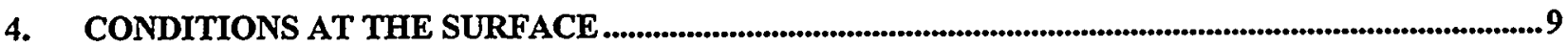

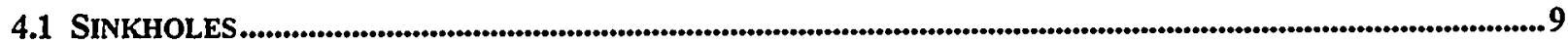

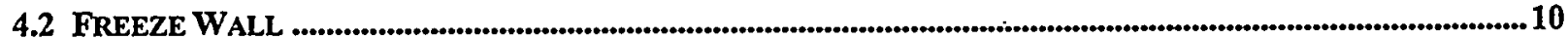

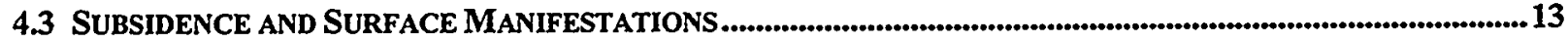

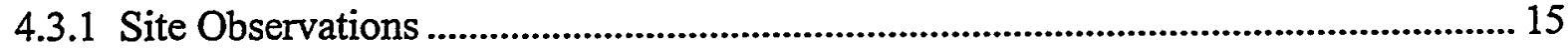

4.3.2 Subsidence Survey Results ........................................................................................ 16

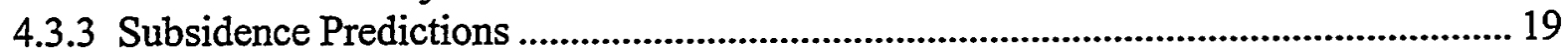

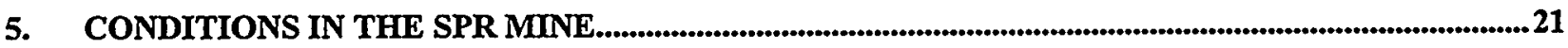

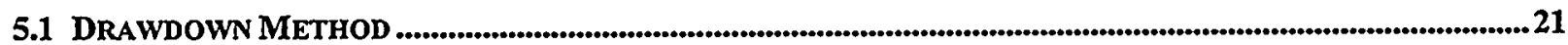

5.2 RECOVERED AND REMAINING CRUDE OIL

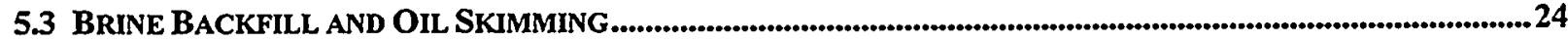

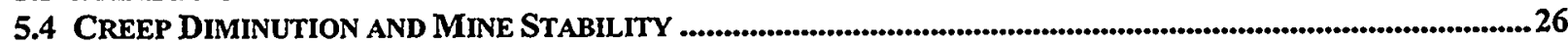

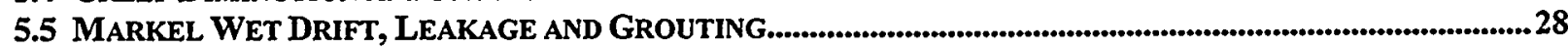

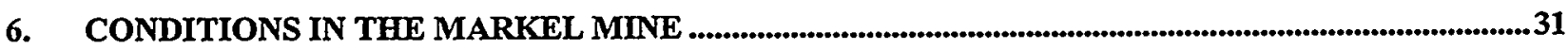

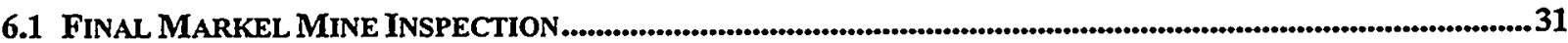

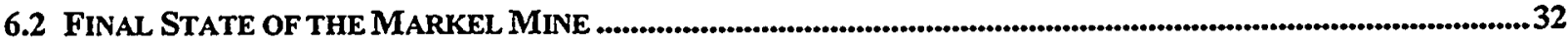

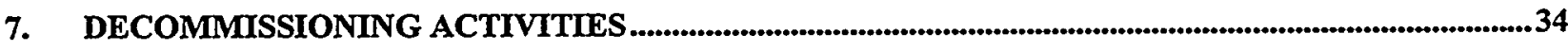

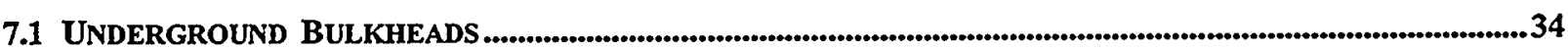

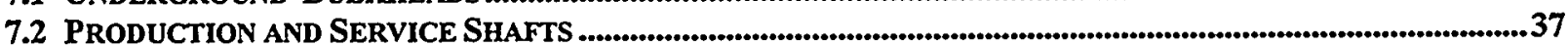

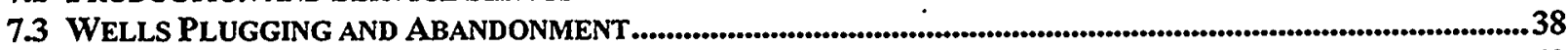

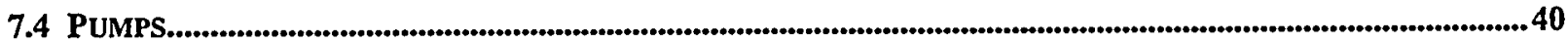

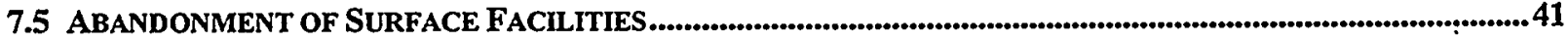

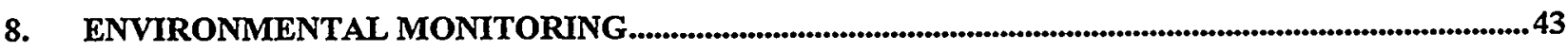

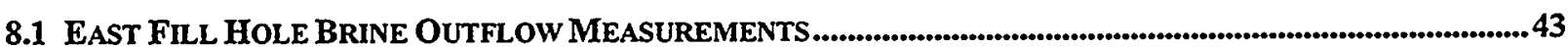

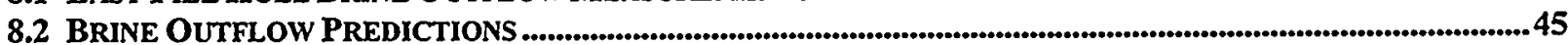

8.3 GROUNDWATER MONITORING FOR HYDROCARBONS..........................................................................................4 46

9. RISK ASSESSMENT RESULTS RELEVANT TO POST-CLOSURE.....................................................47

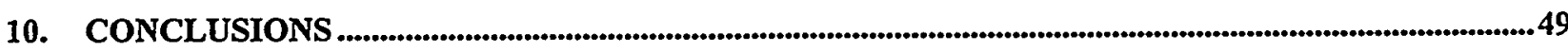

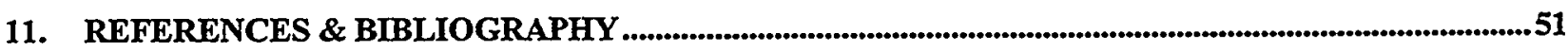

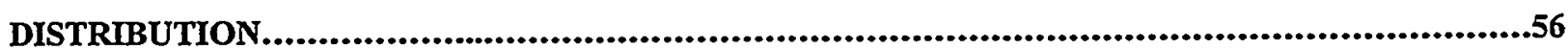




\section{FIGURES}

Figure 3.1 Weeks Island Salt Dome, Mines, and Sinkholes...............................................6

Figure 3.2 Isometric View of Weeks Island Manways............................................................

Figure 3.3 Isometric View of Manways to Markel Mine ......................................................7

Figure 4.1 Sinkhole \#1 Brine Injection Rate as a Function of Time .........................................11

Figure 4.2 Radial Cross-Section through Sinkhole \#1 Freeze Wall and Ice Cap ........................11

Figure 4.3 Site Map with Mine Footprints and Locations of Subsidence Monuments (WI\#)......14

Figure 4.4 Weeks Island Subsidence Rates (ft/year), 2/90-12/92 ...........................................17

Figure 4.5 Weeks Island Subsidence Rates (ft/year), 12/96-9/98 ............................................18

Figure 4.6 Weeks Island Subsidence Rates (ft/year), 3/99-10/99 .............................................18

Figure 4.7 Relationship Between Subsidence and Fluid Level in the Mine................................20

Figure 5.1 Weeks Island Mine Oil Recovery, by Skimming Phase............................................23

Figure 5.2 Weeks Island Mine Brine-Fill Volume vs. Time ......................................................25

Figure 5.3 Weeks Island Mine Brine-Fill Level vs. Time ......................................................25

Figure 5.4 Predicted Potentials of Salt Damage Prior to Decommissioning an Oil Filled Mine .27

Figure 5.5 Predicted Potentials of Salt Damage After Decommissioning for a Brine Filled Mine

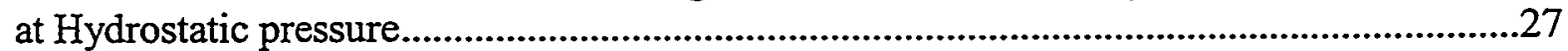

Figure 5.6 Markel Wet Drift Recent Brine Inflow History....................................................29

Figure 7.1 Weeks Island Mine Profile Schematic .............................................................35

Figure 7.2 Production Shaft Relief Bridge Plug ..................................................................36

Figure 7.3 Relative Locations of Monitoring and Exploration Bore Holes.................................41

Figure 8.1 East Fill Hole Brine Flow Measuring Station Schematic..........................................44

\section{TABLES}

Table 5-1 Oil Recovered or Abandoned in the Weeks Island Mine (in bbl) .............................23

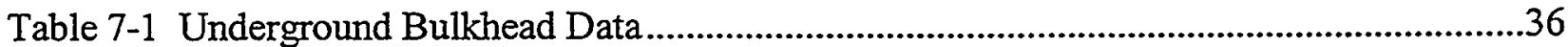

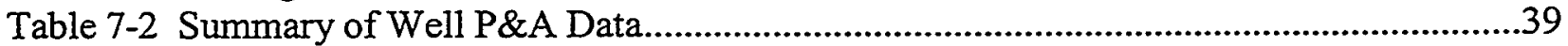




\section{INTRODUCTION AND EXECUTIVE SUMMARY}

Decommissioning and abandonment activities at the Weeks Island Strategic Petroleum Reserve (SPR) site, in Iberia Parish, Louisiana, were essentially completed at the end of 1999. This effort required about six years of intense efforts from the multiple organizations involved. The Department of Energy Strategic Petroleum Reserve Project Management Office (DOE SPR PMO) provided management oversight and support. DynMcDermott Petroleum Operations Company provided operational and engineering support. Sandia National Laboratories provided geotechnical direction and related support activities. Other major contractors providing required support functions included PB-KBB, Walk, Haydel and Associates, Freezewall Inc., Grady Crawford, Acres International, Rembco Engineering, Sofregaz, plus others. The Weeks Island Mine Integrity Management Group (WIMIMG) committee, lead by DOE SPR PMO, formulated most of the decisions on the decommissioning and subsequent required operational tasks for the Weeks Island SPR facility and site. WIMING representatives included personnel from the DOE SPR and many of the mentioned contractors, plus others.

The Weeks Island mine originally opened in 1902 and salt was commercially extracted from it until 1977. In September 1977 this two-level room and pillar mine was acquired from the Morton Salt Company and converted into a crude oil repository, as part of the U.S. Department of Energy Strategic Petroleum Reserve. In February 1979, the State of Louisiana Office of Conservation issued its Order SDS-8 authorizing the DOE to use this mine for SPR oil storage. From 1980 through 1982, the underground facility was filled with approximately 72 to 73 million barrel (bbl) of sour crude oil, and remained at that level until November 8, 1995, when drawdown operations began, as part of the decommissioning process.

The Weeks Island facility decommissioning was initiated following the recognition, geotechnical assessments, and evaluations in 1994 that ground waters were leaking into the stored oil chambers of the SPR mine. The Department of Energy announced in December 1994 that it would decommission the Weeks Island facility because of apparent geotechnical problems that posed a significant risk of future oil loss and potential environmental damage [Neal et al., 1996]. This announcement was based on a critical reassessment of, and multiple diagnostic studies (geologic, geophysical, hydrologic, and others) evaluating the existing geotechnical risks of continuing oil storage at this site, as compiled and detailed separately [Bauer et al., 1994]. The precipitating event for the decommissioning was a sinkhole (Sinkhole \#1) that was discovered in May 1992 over the southern edge of the underground facility.

Investigations undertaken in 1994 [Bauer et al., 1994] and 1995 [Neal and Myers, 1995] into the cause of surface sinkholes (\#1 and a much smaller \#2, first observed in February 1995) verified that water from the surface aquifer above the Weeks Island salt dome was seeping into the underground oil storage chambers at the site. As a result, the DOE SPR recovered and transferred the oil primarily to other SPR storage facilities in Louisiana and Texas. Approximately $\$ 100$ million worth of Weeks Island oil was also sold commercially to help finance the decommissioning and drawdown costs, as well as for other governmental expenses. The overall underground decommissioning processes were greatly complicated by the existence of brine in the mine (leakage into, or added), and the major programmatic concern that the water leak from the sinkhole might become uncontrolled before all the oil could be systematically removed (drawdown), and the mine backfilled with brine. The task of the DOE SPR PMO was to conduct a safe 
drawdown and mine decommissioning, while preventing oil leakage from the mine, successfully averting potential short-term or long-term environmental damage.

The growth of Sinkhole \#1 was successfully controlled by use of a new technique that involved saturated brine injection into the throat of the sinkhole, below the top of the salt dome. In addition, this primary brine leak into the mine was isolated from the aquifer by construction and multi-year maintenance of a $60-\mathrm{ft}$ diameter freeze wall around Sinkhole \#1. This added a further measure of hydrologic and structural control during drawdown of the oil and the following decommissioning stages.

Neal et al. [1996] has already documented comprehensive detail on: the discovery of the sinkholes at Weeks Island; sinkhole characteristics and their behavior for the first several years of their existence; causal factors that led to the formation of the sinkholes; and, the geotechnical diagnostic studies conducted on the sinkholes and on the overall SPR mine and site. These geotechnical studies provided the information necessary to establish and support appropriate DOE SPR actions and schedules, consistent with perceived environmental risks; leading to the Weeks Island Mine decommissioning. Neal et al. [1996] also summarized information on the preliminary actions (through 1996) and plans for the completion of the decommissioning process. Many of these details are referenced throughout much of the remainder of this current document. However, most of the updated information presented in this current report pertains to relevant detail or activities conducted over the last couple years, at the end of the decommissioning process. This report essentially completes the documentation started in Neal et al. [1996].

Removal of about $98 \%$ of the stored crude oil in the Weeks Island mine was accomplished, extending over the time period of late 1995 through 1999; there were several delays resulting from complications in handling of the oil during drawdown and skimming, and associated brine filling activities. The nonrecovered quantity of oil abandoned in the mine, about 1.47 million bbl, was assessed [Molecke et al., 1998; O’Hern et al., 1999] to be stably trapped:

predominantly, in the significant quantities of loose salt remaining in the mine; and,

to a much smaller extent, floating on the brine fill and trapped in many small roof irregularities (undulations in the roof of the mine that occurred as a result of conventional salt mining) distributed throughout the two levels of the mine.

Currently (late 1999), the mine brine backfill is essentially complete, with only very small water additions required to replace the trapped gas permeating into the salt. Almost all of the underground SPR facilities have been plugged and abandoned, with demolition and removal of equipment accomplished. The aboveground site facilities also have been decommissioned. Sale and/or disposition of remaining property and assets, real estate, and mineral rights are currently in process by the U.S. General Services Administration (GSA). At DOE request [Gibson, 1999], the State of Louisiana, Office of Conservation, has issued a Supplement to its Order SDS-8, terminating the DOE authorization to use this mine for oil storage, effective as of September 1 , 1999 [Asprodites, 1999].

In brief summary, the DOE has successfully completed the decommissioning and abandonment of the Weeks Island Strategic Petroleum Reserve site during 1999. These processes required coordinated engineering, operational, geotechnical, and management support, with oil drawdown, brine refill and oil skimming, and numerous plugging and sealing activities. Periodic monitoring of site surface features, subsidence due to salt creep, and sampling of ground waters released from the pressurized mine under controlled conditions, to verify containment of residual 
oil, will continue for five years, through 2004. Based on these monitoring results, the State of Louisiana will then make a decision on whether to continue monitoring activities [Asprodites, 1999].

The main body of this report serves to document and archive important details of the decommissioning and abandonment activities at the Weeks Island site over the last six years. A summary of information is provided on the following relevant topics:

- an overview on the background, selection, and history of the Weeks Island SPR site and

- facilities, for purposes of completeness and easy reference,

- the recent pre- and post-closure conditions of surface features at the site, including the sinkholes, the freeze wall, surface subsidence measurements and predictions, observations on facilities, etc.,

- the most recent pre- and post-closure conditions within the SPR mine and manways, including crude oil recovery, brine filling, the Markel Wet Drift leakage and grouting, etc.,

- conditions within the adjacent, abandoned Markel Mine,

- environmental monitoring activities and plans for periodic brine outflow monitoring and total petroleum hydrocarbons (in brine) monitoring,

- risk assessment evaluations relevant to the decommissioning and long-term periods, including potential environmental impacts, and

- a bibliography of many of the geotechnical evaluations and documents that supported the decommissioning and abandonment of the Weeks Island SPR facility. 


\section{BACKGROUND OF STRATEGIC PETROLEUM RESERVE}

The Strategic Petroleum Reserve was authorized by Congress with the enactment of Public Law 94-163, the Energy Policy and Conservation Act (EPCA), on December 22, 1975. This law established United States policy to store up to one billion barrels of crude oil, to reduce the impact of a severe energy supply interruption and to carry out the obligations of the United States under the International Energy Program. Additional amendments to EPCA [DOE, 1995a] have modified the authorizing legislation, but the initial intent has not changed.

Prior to the enacting legislation, a DOE predecessor agency, the Federal Energy Administration, FEA [FEA, 1977], had worked on the storage concept and contracted two studies earlier in 1975 , one to look at storage in existing leached caverns, and the other in existing mined cavities. Existing mines had the appeal of coming "on line" faster and also multiple withdrawals could be made without enlarging the cavities such as in a leached-cavern storage system [Neal et al., 1996]. Acres American [Acres, 1977], in conjunction with Butler Associates of Tulsa, undertook the latter effort; their Phase 1 report, issued in October 1975, identified 11 potential mines that might be used for storing crude oil. A Phase 1 Addendum report was issued in August of 1976 to address several political and supply distribution concerns. It also recommended that further consideration be given only to five mines, two in limestone (Ironton, Ohio, and Central Rock, Kentucky), and three in salt (Kleer, Texas, Cote Blanche, Louisiana, and Weeks Island, Louisiana) [FEA, 1977].

Phase 2 of the study included FEA's assessment of the Phase 1 report and the decision to proceed with Phase 3 (preliminary design, cost estimates, and construction schedules for each site). The principle employed in mine conversion followed the Scandinavian system, the only comparable underground oil storage facilities in the world at the time. The Swedish storage concept employed bulkheads in the shafts, through which submersible pumps were suspended from the surface, with pump casings passing through the bulkheads. This Swedish system completely averted the need for permanent access underground. However, at Weeks Island, fundamental variations were required to enable salt mining to continue during the conversion. These variations included construction of higher-elevation access manways between the shafts, from which new drifts were driven leading to the Markel Mine, an interim mine developed by Morton Salt Company, to the northwest of the existing Weeks Island mine [Neal et al., 1996]. Further details on the conversion of the Weeks Island mine are described in Section 3. 


\section{SELECTION AND CONVERSION OF THE WEEKS ISLAND MINE}

The Weeks Island salt dome is located 14 miles south of New Iberia, Louisiana, and is the central dome in the Five Islands chain, along with Belle Isle and Cote Blanche to the south, and Avery and Jefferson Islands to the north. All five have been mined because of their near-surface salt, and their logistical advantage near the Gulf of Mexico and the Intracoastal Waterway. Belle Isle and Jefferson Island are now closed to mining because of deliberate and inadvertent flooding, respectively.

All the candidate sites (mentioned in Section 2) except Weeks Island had logistical or op'erational problems, or were limited by volume. The Weeks Island mine was an operational, twolevel room and pillar mine in domal salt. Although geotechnical uncertainties existed at that time, such as the inability to access the upper mine level (for safety reasons), Weeks Island had many desirable attributes, especially volume, location, and availability. Morton Salt, the mine operator at Weeks Island, estimated the volume originally at 89 million barrels, which was a significant advantage over the other candidate sites. The decision to use the Weeks Island mine became an obvious, expedient choice and further studies of mine suitability were instituted. Subsequently, the formal decision to select the Weeks Island site for oil storage underwent public review according to the National Environmental Policy Act decision making process [FEA, 1976; FEA, 1977; Capline DEIS, 1977; Capline FEIS, 1978].

The Weeks Island salt mine was originally opened in 1902 and salt was extracted commercially from the upper level until 1952 and from the lower level between 1952 and 1977. In 1977, Morton Salt began developing its interim, or Markel Mine, and new Morton Mine adjacent and to the northwest, while the older workings were converted for SPR oil storage. The relative locations of the Weeks Island Mine, the interim Markel Mine, and the Morton Mine are illustrated in Figure 3.1.

The FEA acquired the former two-level underground salt mine, consisting of 382.92 acres, and 6.63 acres of surface land, by condemnation from Morton Salt Company in September, 1977 [DOE, 1995a]. As part of the acquisition agreement, FEA (now DOE) agreed to allow Morton to continue salt production until the new Morton Salt mine was sufficiently developed to permit mining. Between 1977 and 1980, the Weeks Island mine was modified in preparation to receive and store crude oil, and Morton Salt's new mine was started. This involved continued use of the existing two (production and service) shafts, while advancing drifts to the interim Markel Mine, and sinking of two new shafts for the new Morton Salt mine. During an 18-month transition interval through 1980, Morton extracted salt from the interim Markel Mine; the Markel Mine was then abandoned in 1980. Further historical detail on the Weeks Island mine acquisition, as well as conversion details, can be found in the Weeks Island Strategic Petroleum Reserve Geological Site Characterization Report [Acres, 1987].

Because Morton intended to maintain an operating mine at the site, the plans for conversion of the existing mine went forward, in conjunction with plans to develop an interim mine, the Markel Mine. Thus, the commercial mining of salt continued simultaneously with development of a new mine. Several innovative solutions were introduced that allowed the continuation of commercial mining. This included continued use of the Production Shaft for hoisting salt, and creation of a manifold room in the 9-ft diameter Service Shaft. This shaft was not large enough to handle all the withdrawal pump casings. The resulting manifold room was $40 \mathrm{ft}$ in diameter 


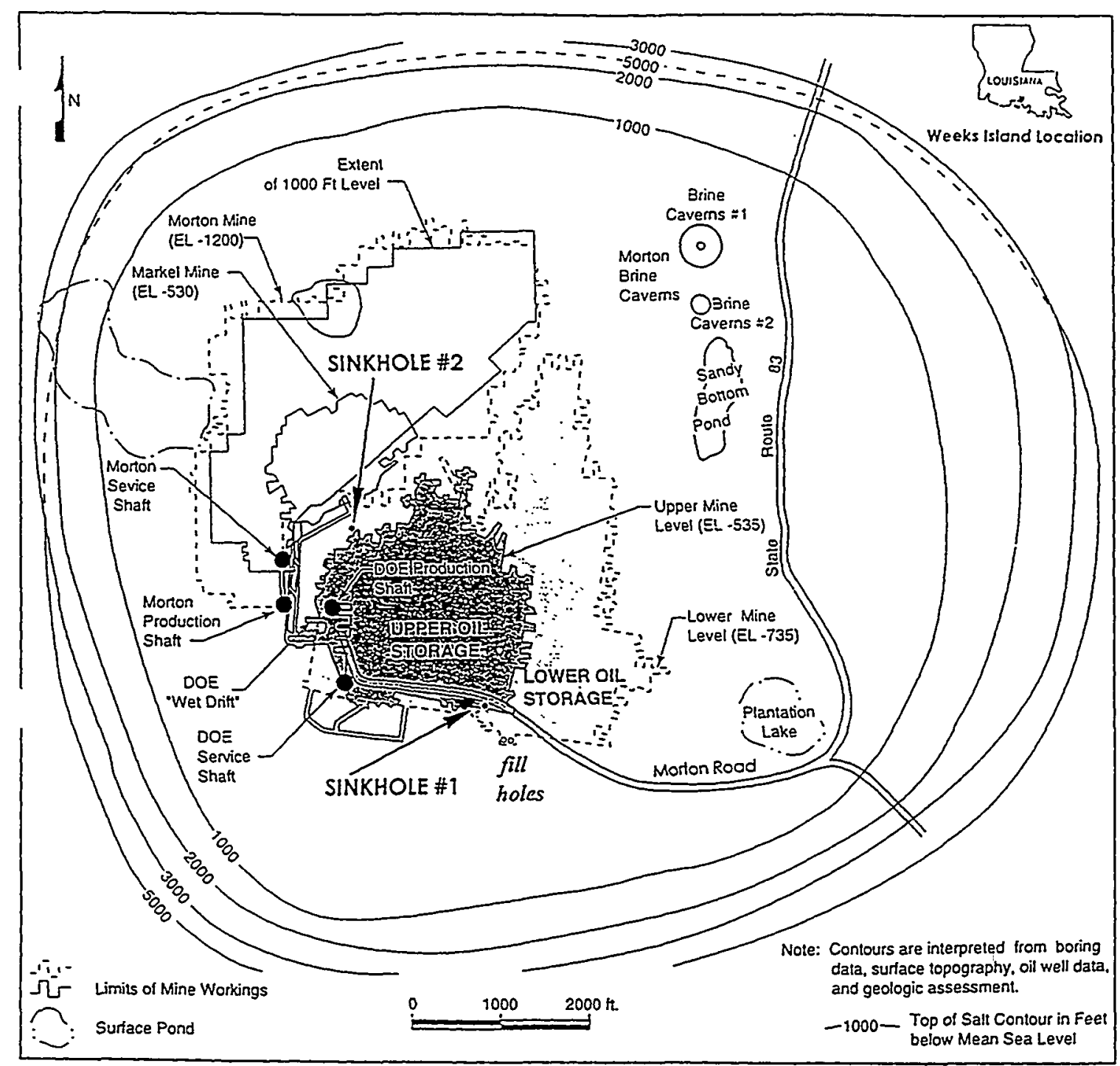

Figure 3.1 Weeks Island Salt Dome, Mines, and Sinkholes

over a height of $80 \mathrm{ft}$, so that individual pump casings could be withdrawn in $40 \mathrm{ft}$ sections and stacked in the manifold room.

While the Weeks Island mine conversion was in progress and the high-level drifts or manways (above the mine) were excavated to connect the Service and Production Shafts, access drifts to the interim Markel Mine were started [Acres, 1987]. The manways and access drifts are shown in Figure 3.2. A drift known as the Markel Incline was driven from the lower level upwards at approximately a $12 \%$ slope to a high point at an elevation of $-370 \mathrm{ft}$. In 1977 , several "wet spots" on the salt of the access drift to the Markel Mine (at a right angle to the Markel Incline) were noticed during routine drilling and blasting, starting on December 8, 1977. Mining activity continued but water leaks developed, initially at about 3-7 gph. Leaks in probe holes led 


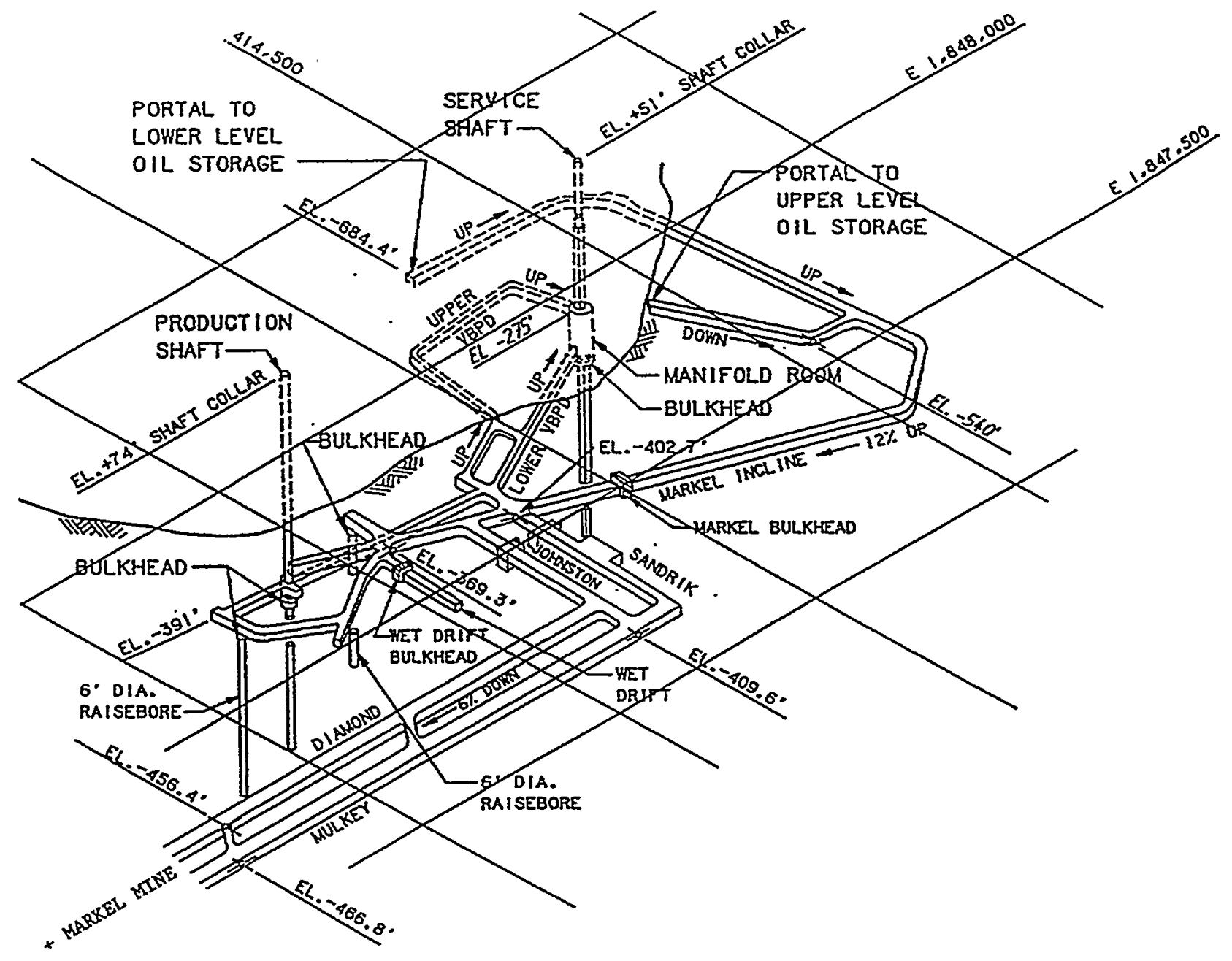

Figure 3.2 Isometric View of Weeks Island Manways

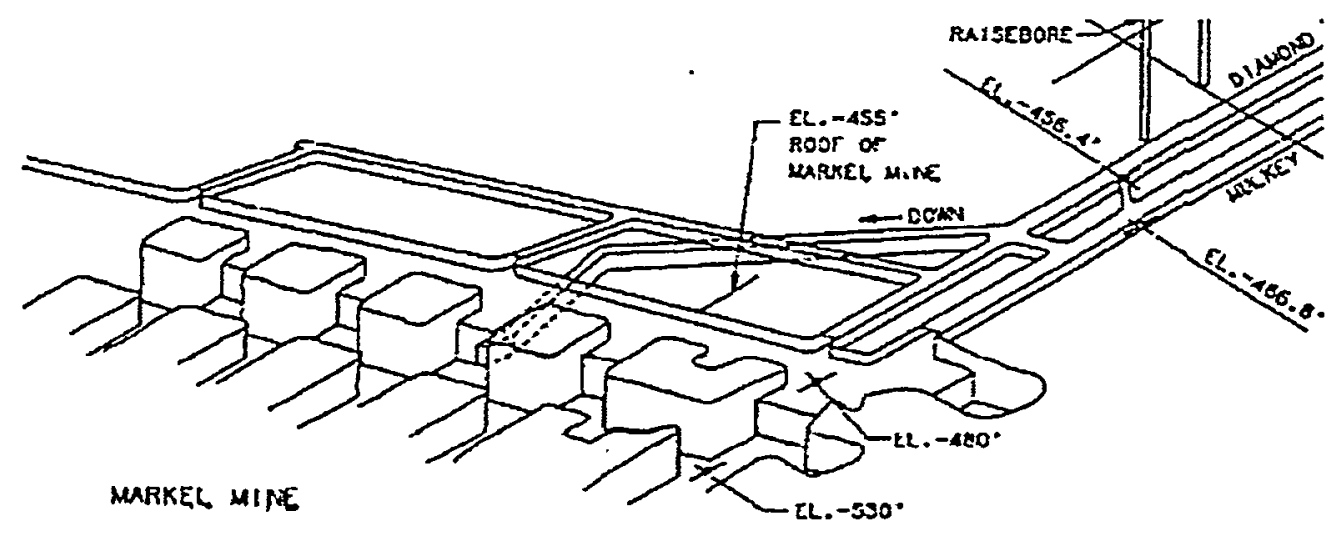

Figure 3.3 Isometric View of Manways to Markel Mine 
to a halt in development of this drift on December 13, 1977. This drift was subsequently named the "Markel Wet Drift;" refer to Figure 3.2. Multiple probe and grouting holes were drilled in the next several months. Leak rates of pressurized brine of about $50 \mathrm{gph}$ and higher were encountered. Grouting holes were drilled from both the surface and Wet Drift under ground; cement and chemical grouts were used to seal the leaks in these holes reducing the inflow to less than 1 gallon per hour, but this drift was discontinued. The brine leakage was attributed to mining this drift too close to the top of salt, thereby intersecting interconnected fracture zones in the salt that allowed meteoric water to enter the mine. Since neither the Markel Mine nor the new Morton Mine had yet been developed, the wet salt was (more recently) attributed to salt dilatant damage induced by subsidence from the original Morton Mine (the Weeks Island SPR mine) [Neal et al., 1996].

Further details on the problems encountered in the Markel Wet Drift, grouting and bulkhead construction to minimize brine inflow and isolate the Wet Drift, monitoring of the brine inflow, etc., have been summarized previously [Neal et al., 1996; Beasley et al, 1985] and are reviewed in Section 5.4. New accessways for development of the Markel Mine (to replace the Markel Wet Drift) were excavated without encountering any major seepage. These access drifts were called the Johnston and Sandrik drifts (Figures 3.2 and 3.3). As Morton continued development of the interim Markel mine, conversion of the old mine workings for SPR use proceeded between 1978 and 1979, and consisted of:

- Scaling and stabilizing rooms and pillars, with removal or securing of loose material that could become entrained in the oil delivery system.

- Construction of an oil sump and grading of the floor toward the pump sump for drainage purposes.

- Developing an internal drain system, including drilling drain holes between mine levels.

- Constructing a manifold room in the Service Shaft and installing piping and pumps.

- Drilling and constructing two oil fill holes.

- Constructing bulkheads in the two shafts, the Markel Incline, the two raisebores, and a vent hole.

- Developing high level manway drifts, oil distribution and control systems, and surface facilities.

In addition to these conversion activities, the Department of Energy applied to the State of Louisiana for authorization to utilize the Weeks Island mine as an oil repository. The Louisiana Department of Natural Resources, Office of Conservation, issued Order No. SDS-8 effective February 16, 1979 to the DOE, authorizing use of the upper and lower mine levels of a conventional room and pillar salt mine at the Weeks Island salt dome as a Strategic Petroleum Reserve site for the storage of crude oil. Subsequently, following completion of conversion work, the mine was filled with approximately 73 million bbl of crude oil, beginning on October 1, 1980 . Oil filling was completed in April 1982.

Meanwhile, the interim Markel mine was operated for 18 months while the two new Morton Mine shafts were sunk. Development of the new Morton Mine began with removal of salt from the $-1200 \mathrm{ft}$ level. The new mine has operated continuously since then, advancing to the $1000 \mathrm{ft}$ level in the late $1980 \mathrm{~s}$, and more recently to the $-1400 \mathrm{ft}$ level. 


\section{CONDITIONS AT THE SURFACE}

\subsection{Sinkholes}

A surface sinkhole of approximate dimensions of 36-ft across and 30-ft deep was first observed at Weeks Island in May 1992. It was estimated to be at least a year old, based on initial surface appearance and subsequent reverse extrapolation of growth rates. The sinkhole location was physically removed from critical surface facilities and underground manways and caused little alarm initially, even though its appearance was striking, being only about $50 \mathrm{ft}$. from the access road (Morton Road, about a mile from State Road 83) to and from the island.

The association of leaks and sinkholes over mines is well established. This occurrence at Weeks Island suggested that groundwater influx into the mine was causing salt dissolution at depth, with associated collapse of soil at the surface [Neal et al., 1996]. Consequently, DOE SPR took an initial "watch and wait" position after discovery, until modeling established the mechanism and predicted the fracturing of salt and, hence, sinkhole formation, in the timeframe and location that the sinkhole was observed. Subsequently, much attention was given to geotechnical characterization of the sinkhole, and to planning its mitigation [Bauer et al., 1994]. The sinkhole was filled with sand in March 1994, to allow easier depth and volume growth monitoring; at that time, its depth had grown to more than $40 \mathrm{ft}$.

Descriptions of sinkhole growth, sand volume infill monitoring, brine inflow monitoring, and sinkhole diagnostic studies were comprehensively documented by Bauer et al. [1994] and Neal et al. [1996, 1997, 1998], and need not be repeated here. These geotechnical, diagnostic studies [Bauer et al.,1994] included: exploratory drilling of multiple test slant boreholes and exploratory wells placed around and into the sinkhole; sinkhole dye injections; geologic characterizations; downhole flow measurements; seismic reflection profiling; cross-well seismic tomography; surface self-potential surveying; near-surface gas mapping [Carney et al., 1995; Molecke et al., 1996]; hydrologic investigations; and, brine hydrochemistry studies. Further evaluations of sinkhole causal factors and rock mechanics modeling of the mine [Ehgartner, 1993; Hoffman, 1994b; Hoffman and Ehgartner, 1996] were also summarized in Neal et al. [1996, 1997, 1998].

Starting in late 1993, inspections of the Weeks Island surface, particularly the surface overlaying the perimeter of the SPR mine, were conducted to search for other existing or incipient sinkholes, or other dissolution or subsidence features (refer to Section 4.3.1). Starting in 1995 , and continuing through summer 1999, these perimeter inspections were conducted on an approximate quarterly basis. Quarterly inspections were stopped when the mine was backfilled with brine (refer to Section 5.2), essentially eliminating the likelihood of new sinkhole formation. It is anticipated that yearly surface inspections will continue for about the next five years.

Nearly three years after the discovery of Sinkhole \#1, a second and much smaller sinkhole (14-ft diameter, 10-ft deep) was identified in early 1995, located on an opposite side of the mine, but in a similar geologic setting. Both sinkhole locations were determined to be directly over the periphery of the SPR oil storage chambers, where the boundaries of the upper and lower levels of the former room-and-pillar salt mine are nearly vertically aligned. Sinkhole \#1 was over the southern perimeter and Sinkhole \#2 was over the northwest corner perimeter (refer to Figure 3.1). Such location coincidence maximizes the development of tensional stress, leading to fracturing in the salt. Such fracturing takes many years to develop, eventually causing fresh water to leak into the storage chamber and dissolve the overlying salt, thus causing overburden collapse 
into the void [Neal et al., 1996, 1997, 1998]. The second sinkhole caused additional apprehension as this occurrence suggested that ground-water influx with resultant salt dissolution at shallow depth was not totally confined to one location (i.e., at Sinkhole \#1).

If the flow of fresh water down the sinkhole conduit could be inhibited; the potential for salt dissolution would be reduced, the growth rate of the sinkhole minimized, and the flow rate increase slowed dramatically. Diamond and Mills [1994] suggested that saturated brine be injected deep into and below the sand-filled, Sinkhole \#1 conduit at a rate higher than the rate of flow downward to the mine. Starting in August 1994, saturated brine was gravity injected into the throat of Sinkhole \#1, just below the salt interface. The brine was injected through borehole BH7A (refer to Figure 4.2) through most of 1995; brine injection was then switched over to exploratory borehole EH3. The brine displaced local under-saturated groundwater (brine) at the top of salt. Some of the injected brine flowed down into the mine, the rest flowed up and out of the throat, as evidenced by the upward flow recorded by installed flowmeters. The average daily brine injection rate for most of 1995, via BH7A, ranged between about 150 to 280 gallons/hour (gph) ( 86 to $160 \mathrm{bbl} /$ day). Figure 4.1 illustrates the rate of injection of saturated brine into the sinkhole via EH3, as a function of time, from late 1995 through June 1999.

The use of this new technique was successful since almost no additional Sinkhole \#1 subsidence occurred following the introduction of the brine. The further dissolution of salt was virtually arrested, and virtually no downward movement of fill sand was measurable. This marked the first time that such mitigation of a sinkhole in salt had been achieved without downhole grouting [Neal et al., 1996, 1997, 1998]. This is also the first known control of a sinkhole-salt mine leak by saturated brine injection. Sinkhole brine injection was continued until August 1999, following oil drawdown and brine fill (refer to Section 5.3), when the mine attained hydrostatic pressure.

In addition to the brine injection procedure, the primary brine leak into the mine was isolated by construction and multi-year maintenance of a 60 -ft diameter freeze wall around Sinkhole \#1. This added a further measure of hydrologic control during drawdown, in addition to structural control of the sinkhole. The freeze wall is discussed in more detail in Section 4.2. Sinkhole \#1 remained basically unchanged in size following the addition of the freeze wall.

Sinkhole \#2 was filled with sand in 1995 and monitored closely; no brine injection or freezewall construction was considered necessary nor implemented. This sinkhole remained essentially unchanged in size, in a quasi-static condition, until the middle of 1998, when it started to deepen steadily (by a total of about $3 \mathrm{ft}$ ). The observed rate of deepening, about $0.1 \mathrm{ft} /$ week, corresponded to a leak into the mine of about $1 \mathrm{bbl} /$ day [Hinkebein and Linn, 1998]. A monitor and wait approach was undertaken; no further significant sinkhole enlargement occurred between February 1999 and the time that the mine was filled with brine (refer to Section 5.3), ending concern about the sinkholes.

\subsection{Freeze Wall}

In late 1994, the progression of sinkhole causative factors seemed inevitable, the long-term effects of brine injection unknown, and the increasing risks of surface collapse during oil removal were unacceptable. As such, DOE SPR implemented a plan [DOE, 1995c] that included the construction of a freeze wall around Sinkhole \#1. The freeze wall was intended to form a barrier to limit hydrologic inflow in the event of catastrophic increase in the mine inflow rate. 


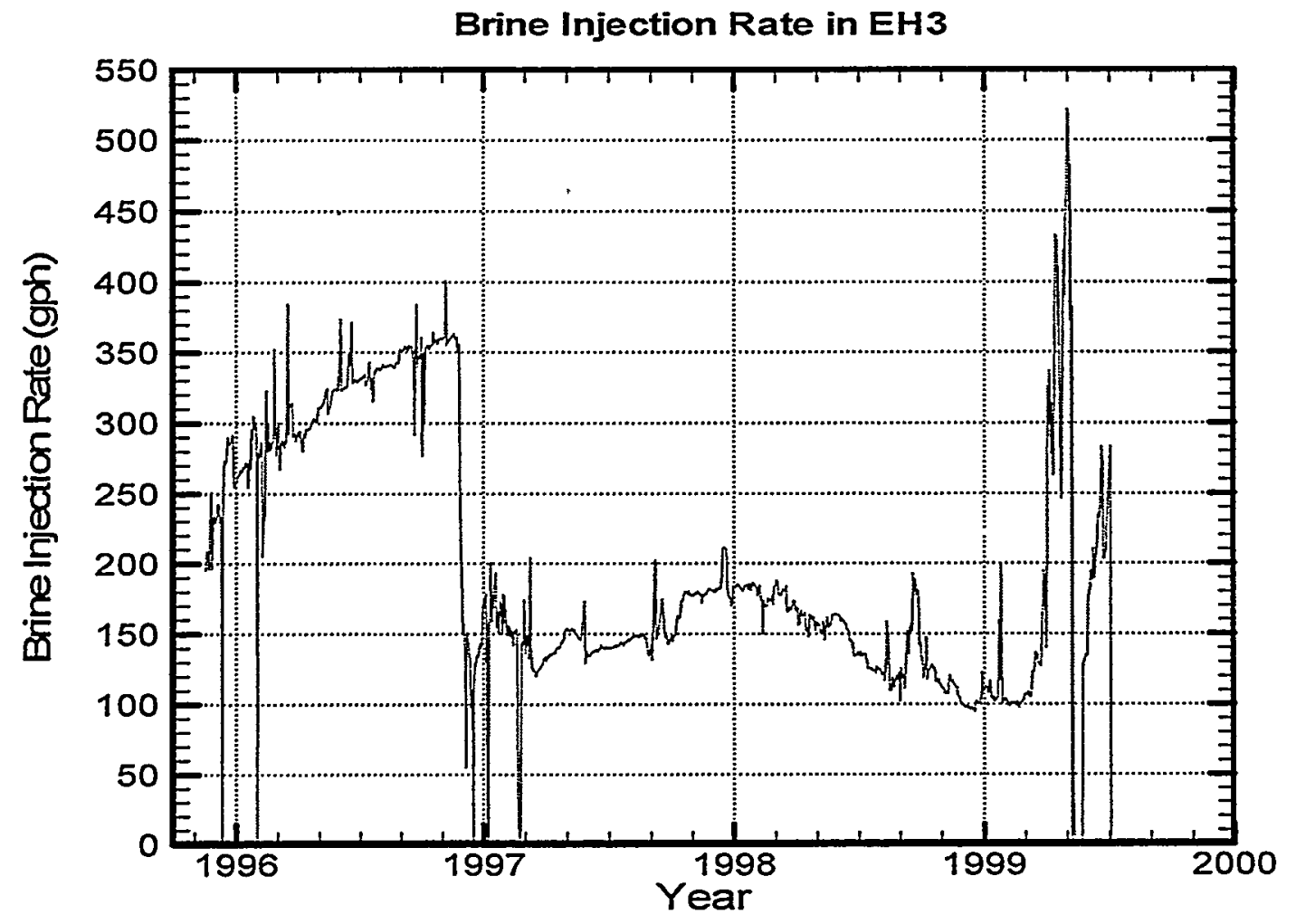

Figure 4.1 Sinkhole \#1 Brine Injection Rate as a Function of Time

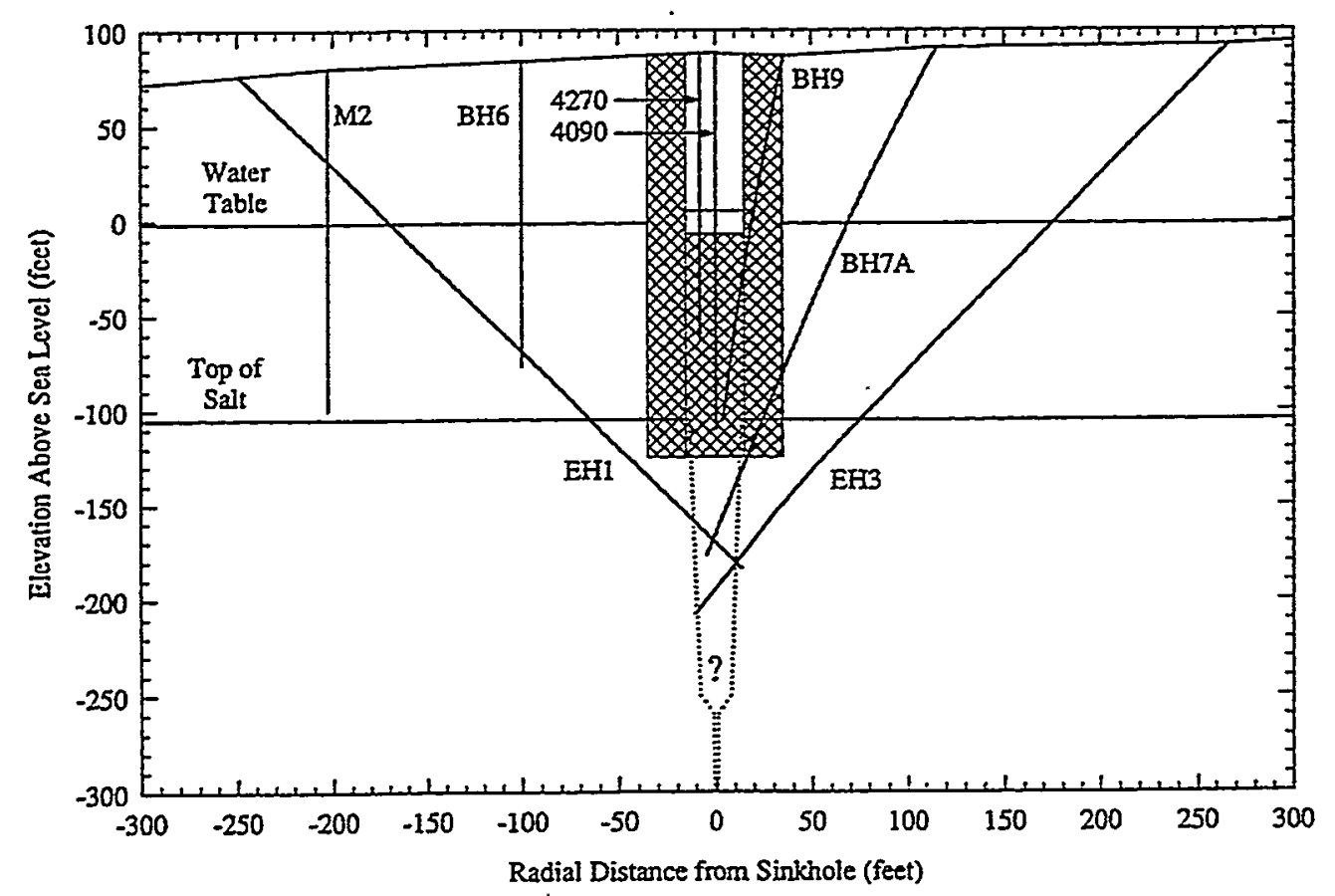

Figure 4.2 Radial Cross-Section through Sinkhole \#1 Freeze Wall and Ice Cap 
Freeze walls are common tools used in underground construction. For example, as traditionally used in mine shaft sinkings, a perimeter of subsurface, soft water-laden ground is frozen; within that frozen perimeter, the ground is then excavated and ground support is installed. The freezing provides shear strength to the soil surrounding the excavation. Sometimes, the freezing process is used to prevent groundwater movement in and through an excavated area, e.g., a shaft, while ground support and/or water incursion prevention means are being installed. For the Weeks Island sinkhole application, the sand-filled Sinkhole \#1 was not excavated. This freeze wall was designed (by the subcontractor, Freezewall, Inc.) to freeze the ground around and under the sinkhole, including the sand fill, from the top of the water table down into the top of salt. The freeze wall was intended to present a barrier to further groundwater movement in the vicinity of the leak, and provided mechanical integrity to the ground in, and adjacent to, the sinkhole area.

A freeze wall is constructed by drilling into the region to be frozen. The holes are cased. An inner casing is inserted and grouted into the cased holes. Refrigerated coolant is circulated down the annulus and up, and out, the inner tube from a surface refrigeration plant. The coolant holes and surrounding region are monitored to determine the temperature field as a function of time and position, thus making possible predictions on the geometry of the frozen mass of ground.

The construction of the Weeks Island freeze wall began in June 1995 and was completed within five months [Neal et al., 1996]. Holes were drilled using brine-saturated drilling mud through approximately $185 \mathrm{ft}$ of unconsolidated sediment. The holes were completed approximately ten to twenty $\mathrm{ft}$ into the top of salt, with steel casing cemented into position. This placement assured that any fluid-filled fractures in the top of salt would eventually be frozen. The wall was formed by chilling calcium chloride refrigerant to an average temperature of $-38^{\circ} \mathrm{C}\left(-36^{\circ} \mathrm{F}\right)$ and circulating it in 54 wells constructed in three circumferential rings around the sinkhole. The outer ring of twenty two wells, with a diameter of $54 \mathrm{ft}$, was drilled approximately $10 \mathrm{ft}$ into salt $(-125 \mathrm{ft}$ MSL) to anchor the freeze wall into the salt stock. The middle ring of twenty two wells, with a diameter of $48 \mathrm{ft}$, was drilled at or slightly into the salt (-115 ft MSL). The inner ring of 10 wells with a diameter of $40 \mathrm{ft}$ was placed at the top of the salt. Five of the inner ring of wells did not tag salt and were assumed to be in the area of the sand-filled sinkhole cavity. Drilling of the freeze wells included the innovative use of a movable rig platform straddling the sinkhole periphery and mounted on rails outside the well area. This allowed freezing to commence on the outer ring while the inner ring wells were being drilled and prepared. At times, there were three drill rigs in operation simultaneously within the relatively small area.

The freeze wall was declared complete and ready to test by the subcontractor, Freezewall, Inc., on October 15, 1995, but tests failed to confirm hydrologic isolation. Freezing continued and thermal profiles indicated that the desired integrity was achieved on November 1, 1995. The testing provided confirmation that an essential hydrologic barrier had been achieved, and on November 6th the freeze wall was declared ready to support oil drawdown, which started two days later.

The final configuration of the freeze wall for drawdown was an ice cylinder $20-\mathrm{ft}$ thick with a nominal outside diameter of $70 \mathrm{ft}$. Continued freezing formed an essentially cylindrical ice wall in the zone of saturated ground water, between the ground surface and the top of salt. The brine levels in the freeze wells were modified in April 1996 to concentrate freezing at the lower depths, near the top of salt ( -80 to $-125 \mathrm{ft} \mathrm{MSL}$ ). The resultant "ice cap" (plug) functioned similarly to the ice wall cylinder, but required less energy to maintain. Figure 4.2 shows a radial 
cross-section through the freeze wall and ice cap; it also shows several of the test and monitoring boreholes in the near vicinity.

The freeze wall and ice cap were maintained for over three years, until the crude oil storage chambers were emptied of crude oil and filled with brine to hydrostatic pressure in August 1999. On August 2, 1999, the Freezewall operations (chillers) were turned off and the freeze plug allowed to begin to thaw in response to the ambient subsurface conditions since that time. No abnormal subsidence in this sinkhole vicinity has yet been observed. Estimates of total salt leached due to both fresh water used sparingly to clean the freeze wall injection and maintenance wells when necessary, and solutioning due to undersaturated brine (thermal effects) have been made. The total leached volume may or may not manifest itself as further, future sinkhole subsidence, but it is estimated to be only a few inches within the original diameter of Sinkhole \#1. Gross time estimates of a few months were made for this subsidence, but detailed modeling was not performed.

\subsection{Subsidence and Surface Manifestations}

Since January 1983, the subsidence monument elevations at the Weeks Island site have been surveyed 15 times [Bauer and Ehgartner, 1999]. Bauer and Neal [1997] and Bauer [1999a] have most recently reported on the earlier survey data. Figure 4.3 is a base map of a portion of the Weeks Island site showing the footprint of the oil storage facilities and locations of a portion of the subsidence monuments (denoted as WI\#). The changes in elevation, the rates of subsidence, as well as projections of future elevation changes are presented. Of specific interest to the DOE at Weeks Island is the areal and localized subsidence rate of the surface. At Weeks Island, owing to general high elevations, absolute elevations are not of paramount importance.

At Weeks Island and other SPR sites in general, elevation changes are primarily due to creep closure of caverns. The acquired survey data indicated general subsidence on the scale of the overall site or portions of the site. These subsidence measurements capture surface manifestations of creep closure of underground openings.

Subsidence is important because of general concerns for safety and site operations, prior to decommissioning. Localized subsidence adversely affected the infrastructure of the site. Site facilities (electrical, mechanical, and transportation systems, including hoist equipment, ventilation, pipelines, roads, etc.) were damaged to some small degree. Severe subsidence may impact future operations of the overall infrastructure. Subsidence at Weeks Island was assumed to have caused (or, conversely, was to some extent due to) salt fracturing, with subsequent water leakage into the mine. Water leakage led to sinkhole development and, as a consequence, to the site decommissioning process.

Subsidence information was obtained in two ways, leveling surveys and visual observations. For the leveling surveys, elevation data represents the raw data. The measurements were made at various time intervals and over approximately a three square mile area. The number of data points varied between measurements because loss of monuments occurred through destruction and damage. Further detail of subsidence measurement procedures are described in [Bauer and Ehgartner, 1999].

Because of the extensive underground excavations at Weeks Island, subsidence over the large-scale area would be expected in the survey data. This type of subsidence captures gross effects of creep closure of underground salt openings. However, the surveys may also show pre- 
cursors to localized subsidence. Although observations from extensive surface inspections across the site were conducted quarterly (until summer, 1999), localized subsidence and effects that manifest themselves as potential safety hazards were more likely to be seen by site personnel, as happened in 1998. However, the detailed long term subsidence measurements provided by the surveys are important, especially because they permit the long term extrapolation of elevation changes into the future and provide a metric to evaluate numerical analyses [Hoffman and Ehgartner, 1996].

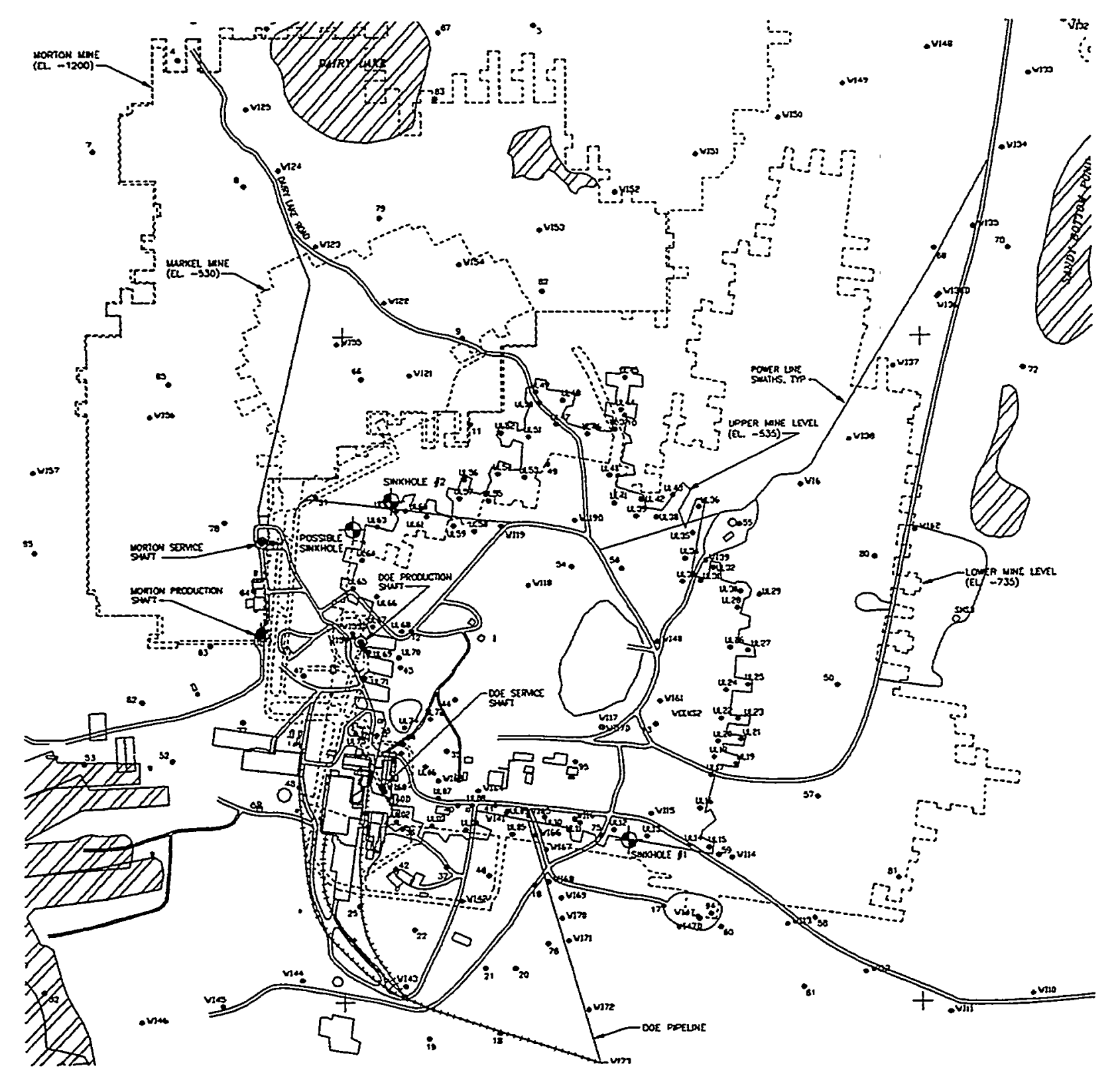

Figure 4.3 Site Map with Mine Footprints and Locations of Subsidence Monuments (WI\#) 
The earliest known survey data for Weeks Island dates back to 1931. The questionable quality and limited amount of information on that survey prevents further analysis, but the magnitude of subsidence as inferred from those measurements indicated approximately $12 \mathrm{ft}$ of subsidence over the central portion of the mine. The effects of deformation on this order can be observed at the site.

\subsubsection{Site Observations}

Weeks Island and other salt mine operations in the Gulf Coast region have been regularly visited by SPR program personnel for more than the last five years. Unpublished observations [Bauer and Ehgartner, 1999] were made of subsidence related deformation of surface structures and associated maintenance/repair activities, with special attention paid to the surface facilities in the immediate vicinity of shafts. Observations of the nature described are not uncommon at salt mine facilities; these observations demonstrate a number of deformational mechanisms associated with subsidence. Descriptions of observations of deformations of site facilities at the Weeks Island site follow.

Inspections of the Production Shaft building at Weeks Island in the Fall 1998 were made in conjunction with other site related work [Bauer,1998a, 1998b]. Observations of the exterior of the building showed striking compressional features on the northeast side of the building, including bent or sheared fiberglass sheeting with displaced nail holes. The deformation was accommodated on the southwest side of the building with extensile features such as stretched nail holes in the fiberglass sheeting, horizontal cracks in the basal blocks of the building, and vertical cracks in the airlock. Photographs of these observations, plus others to be described, are found in [Bauer and Ehgartner, 1999]. In addition, the airlock room appeared to be separating from the rest of the Production Shaft building. These observations, by themselves, suggested only superficial damage to the building and did not indicate any loss in function of either the shaft building or the adjacent airlock building.

In addition, the Production Shaft building appeared to be leaning to the northeast, towards the center of subsidence over the mine. Evidence of the origin of this leaning was seen inside the building. The floor may be described as an inner collar that comes right up to the shaft edge, and an outer collar area. In places, there was a horizontal separation between the two collar segments. Little to no relative vertical displacement was observed at this parted interface. The joint had more than half an inch of horizontal offset in places. Both the inner collar and outer collar were cracked, with the outer collar much more heavily cracked.

The outer collar cracks first aroused site personnel attention in 1998, fostering a closer look at subsidence analyses [Bauer and Linn, 1998]. At that time, it was determined that about 2 inches of differential subsidence had occurred across the building foundation during the past 40 years. Knowledge of the details of this differential subsidence and crack patterns in the pad could allow one to determine a cause and effect relationship between the subsidence and slab cracking.

The cracked concrete pad had some vertical displacement immediately above the shaft liner where the inner collar appeared to be lifted about an inch. This amount of displacement was consistent with the amount of cracking in the 3- to 4-ft thick concrete pad. The fiberglass panels inside the building were buckled in places, a stair rail bent, and a steel joint cracked adjacent to a bent steel member. Some leaning of the building frame had likely occurred, and some nonstructural elements had deformed in response. The function of all of these elements had been maintained, however. 
Deformation immediately around the shaft itself also was observed. The lift guides were tied into two opposed, massive horizontal timbers through an intervening steel plate. There was a horizontal crack in each of the members immediately below where the guides were tied to the massive horizontal timber members. The crack in each opposing member appeared widest (about $1 / 2$ inch) at the center of the timber and died out at the ends. It appeared that the timbers were being pulled upward from where they are fastened to the vertical guides. One corner of the inner collar had localized deformation in the form of cracking and shear displacement. No cracks were observed in either of the cross timbers that run perpendicular to those connected to the lift guides. It is important to note that no cracks were observed in the vertical lift guide timbers. The function of the system was again retained.

Previous work [Bauer and Linn, 1998] has been cited that gives a potential cause and effect relationship between subsidence and cracking observed in the concrete of the hoist building floor. The direction of leaning of the hoist building was consistent with the subsidence gradient from a direction of less subsidence on the mine edge (west side of hoist building) to more subsidence (east side of hoist building), directly over the mine. As noted previously, phenomena of this nature are not uncommon in the vicinity of shafts at salt mines.

During a recent surface inspection [Bauer, 1998a, 1998b], evidence of possible effects of subsidence upon other DOE SPR structures was observed, some inside the DOE main complex that was indicative of damage to surface facilities. The brick fascia on the corners of the administration building had vertical cracks and attendant displacement. The concrete walkway on the south of the administration building and the one to the west of the old guard house were cracked and displaced. A pipe support was sinking away from the pipe it was supposed to be supporting and a concrete abutment had rotated. These observations should be expected in facilities that overlie ground across which considerable differential subsidence has occurred. The function of these facilities had not been effected by the deformations present. Further, these observations led to an increased awareness of subsidence and its effects on surface facilities, an increase in the frequency of subsidence measurements, and a more aggressive attitude towards brine refill of the mine at that time.

Damage to surface structures that was observed [Bauer and Ehgartner, 1999] near the end of the site decommissioning process was attributed to the continued subsidence and differential subsidence across structures. This type of deformation is not uncommon at other shaft building facilities above Gulf Coast salt mines. Damage of this type should be anticipated at SPR facilities wherever differential subsidence of sufficient magnitude occurs. None of the observed damage caused loss of function of the various Weeks Island facilities prior to their decommissioning.

\subsubsection{Subsidence Survey Results}

Subsidence rate data over the period of 1983 through December 1996 were documented in [Bauer and Ehgartner, 1999]. Subsidence rates were due to creep closure of the underlying oil storage facility and the adjacent Morton Mine. From 1983-1990, the area surveyed was relatively small, about a quarter square mile, compared to the DOE property boundary, and contained about twenty measurement stations. The subsidence rate averaged between 0 to $0.1 \mathrm{ft} /$ year during this time period, but only one station was located over the center of the SPR mine.

During the 1990-1992 time period, survey measurements presented in Figure 4.4 clearly showed an increase in subsidence rates [Bauer, 1999a]. The expanded, nearly three square mile area shown in Figure 4.4 encompasses the DOE SPR facility and a portion of the Morton Mine to 


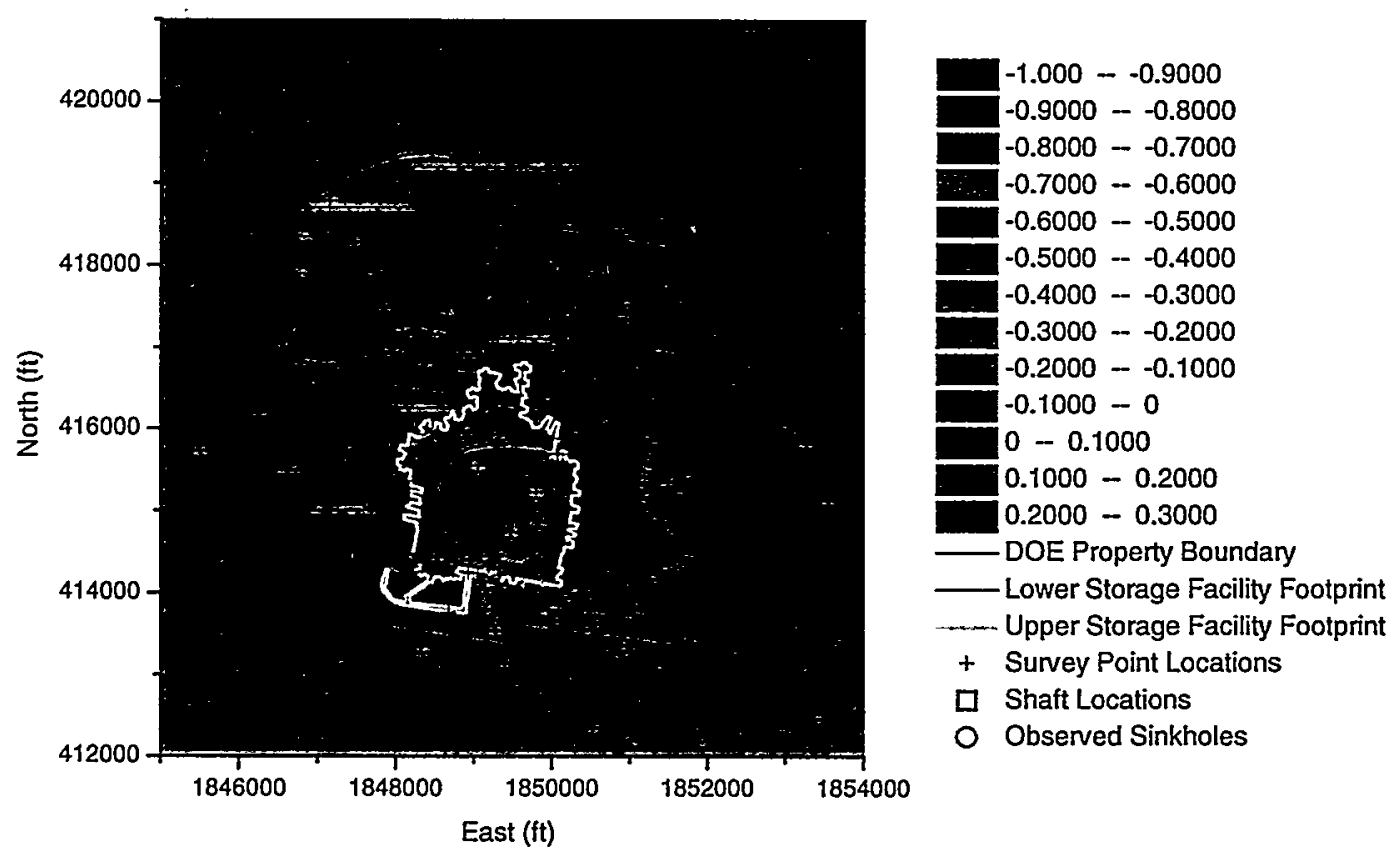

Figure 4.4 Weeks Island Subsidence Rates (ft/year), 2/90-12/92

the northwest, both with measured subsidence rates of 0.1 to $0.2 \mathrm{ft} /$ year. These rates were greater than those measured in 1983-1990, possibly because of both the increased number of survey point monuments added in this area and because of greater accuracy compared to the earlier surveys. The Weeks Island and Morton mine locations were surrounded by more stable areas, with measured subsidence rates of 0 to $0.1 \mathrm{ft} /$ year. An important peripheral observation during this time period from the data gathered was the consistent, continued rise of the Weeks Island salt dome, at an uplift rate of about $0.008 \mathrm{ft} /$ year [Acres, 1987].

The overall subsidence rates from 1992-1995 appeared very similar to those in 1990-1992. However, the observed rates [Bauer, 1999a] for February 1995 through December 1996 over the Weeks Island SPR mine increased, up to 0.2-0.3 ft/year. This subsidence increase reflected the increased closure of the oil-storage levels as a result of oil drawdown from the SPR mine, which started in November 1995.

The results of Weeks Island elevation data obtained from December 1996 to September 1998 are shown in Figure 4.5. This represents the period after oil drawdown and during initial brine fill of the mine. Figure 4.5 shows that the subsidence rates over the SPR facility increased markedly. Maximum subsidence rates were near $1 \mathrm{ft} /$ year, located in the southeast corner of the area denoted by "Upper Storage Facility." Subsidence rate increases observed for most of the SPR facility area were in the 0.3 to $0.5 \mathrm{ft} /$ year range. Local rates increased by a factor of up to four to five, whereas overall rates increased by a factor of two to three. Subsidence rate increases of two to three were also observed to the northwest, over the Morton Salt facility. The white 


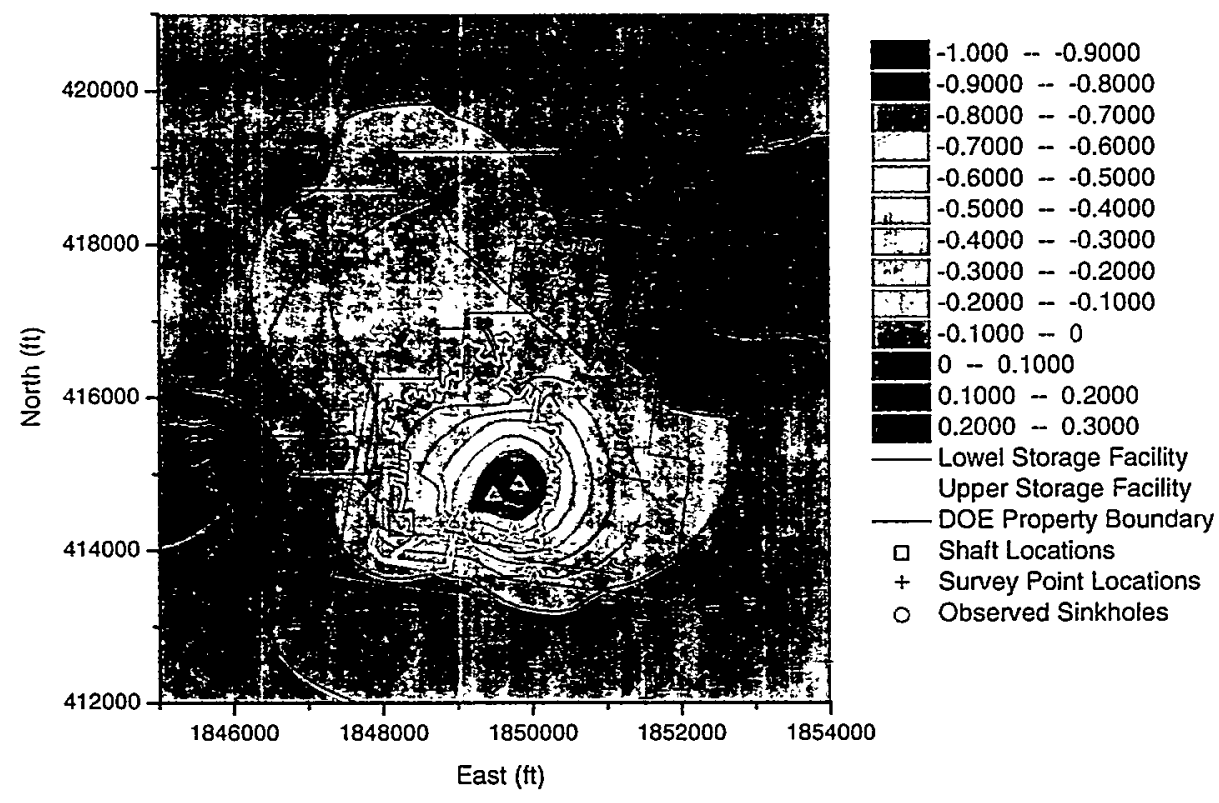

Figure 4.5 Weeks Island Subsidence Rates (ft/year), 12/96-9/98

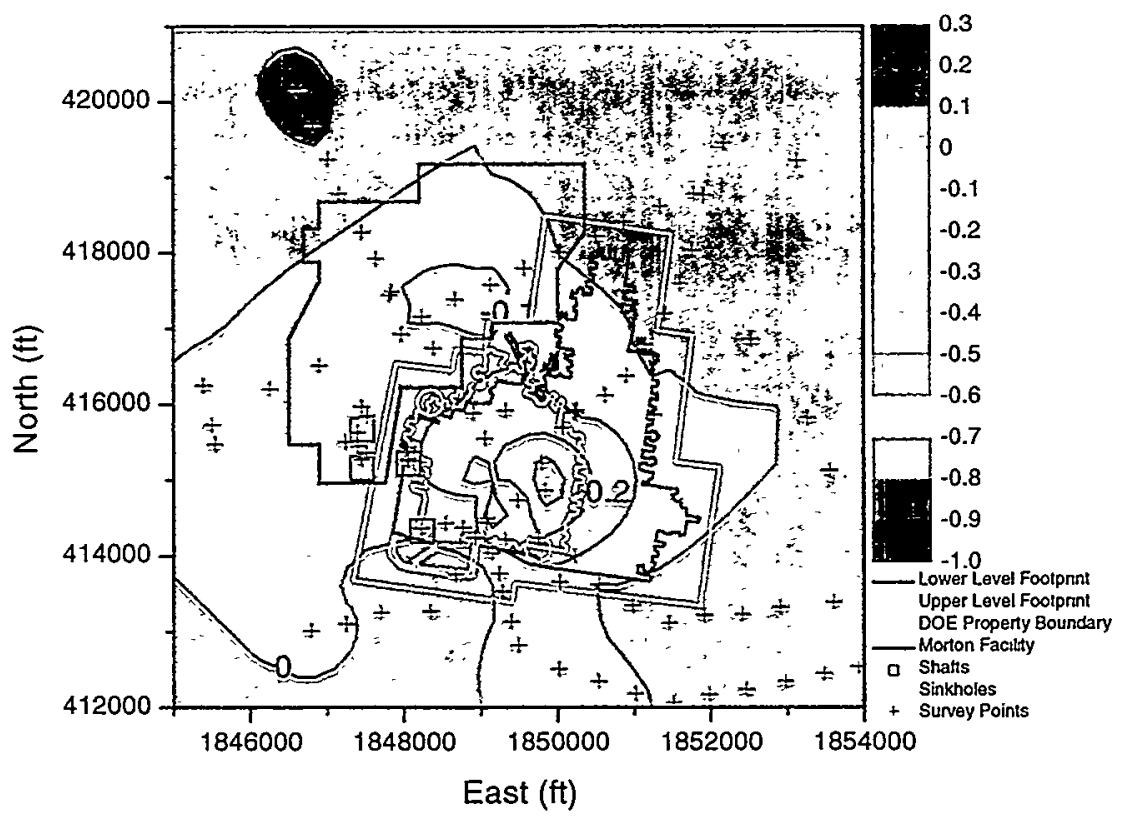

Figure 4.6 Weeks Island Subsidence Rates (ft/year), 3/99-10/99 
triangles in Figure 4.5 represent stations that experienced a factor of three or greater increase in subsidence rate. These increases in subsidence rates were consistent with the data collected near Sinkhole \#1 for the time period of early-mid 1997. Those data showed that subsidence near Sinkhole \#1 was consistent with observed subsidence over other areas of the mine. For the December 1996 to September 1998 measurements, increased subsidence was observed predominantly over the SPR oil storage facility and Morton facilities. These high rate increases were attributed to the emptying of oil in the mine, leaving a partially empty mine, followed with the subsequent brine filling process.

The most recent subsidence data available from the Weeks island site [Bauer, 1999b] covers multiple time periods from December 1998 through October 1999, during the final stages of mine brine filling and afterwards. The data from March to October 1999 are plotted in Figure 4.6 , as subsidence rates as a function of position. These data were viewed by increasing the time span of rate calculation, to yield the effect of smoothing out apparently high and low subsidence rates, decreasing the apparent magnification effect caused by viewing shorter time periods. Six to seven month time period rates were calculated from September of 1998 to the most recent measurements. Based on these data, subsidence rates at Weeks Island have decreased, and are continuing to decrease. Subsidence rates over the central portion of the SPR facility are still in the range of 0.2 to $0.3 \mathrm{ft} /$ year, greater than predicted values. The rates over the mine are not yet on par with those over the Morton Mine.

It is clear that the trend of subsidence measurements indicate a decrease in subsidence rates occurring since December 1998. This observation is consistent with analysis predictions that the back-pressure provided by the brine refill should act to decrease mine closure rates, as compared to rates experienced for an empty mine. It appears that the trend toward lower subsidence rates has been established at Weeks Island. The last measurements included a time period where the mine was full (brine filled). The enhancement effect of moisture content on creep also may be waning. The subsidence survey frequency is anticipated to continue at quarterly intervals until subsidence rates are significantly reduced [Bauer, 1999b]. Current plans are to continue subsidence survey monitoring at Weeks Island for five years following SPR facility decommissioning.

\subsubsection{Subsidence Predictions}

The change in the subsidence rates over the DOE SPR facility is related to the creep closure of the mine. The mine closure rate was influenced by several mechanisms, including the stress state which has changed in the mine and storage facility over time. At the DOE facility, the stress state is determined by the facility depth, internal geometry, and fill condition (oil filled, or partially oil filled, empty, partially brine filled, or brine filled). The internal geometry has remained relatively constant since the DOE assumed ownership of the facility, however, the fill condition changed with time. The mine was empty until 1980. It was oil filled by April 1982 and remained filled until November 1995. At that time, removal of oil from the mine began and took about nine months to complete. Since then, the mine had various levels of brine refill to accommodate several oil-skimming phases. Changes in the stress state during oil removal were predicted to result in a $60 \%$ subsidence rate increase [Hoffman, 1994a]. The predicted rate agreed closely with the measured rate at that time. However, the analyses could not account for the measured subsidence rate increase during brine fill. Figure 4.6 shows the relationship between measured and predicted subsidence rates with time and the fluid level in the mine. The predicted rates are an average for the time period between subsidence surveys and are based on stressdependent salt creep models. 
The brine used for refill was nominally $85 \%$ saturated. This brine quality facilitated some dissolution of the mine surfaces, but these surfaces consisted of spalled and damaged salt, which provided little to no structural support, and piles of crushed salt which were spread out over the mine floor. Therefore, dissolution is believed to have had a small role in subsidence changes at the site. The spalled pillars had no adverse consequence on mine stability. This was evidenced by the long history that the pillars had in supporting the ground. Stability was inferred through the relatively small and steady subsidence rates measured prior to oil withdrawal. Spalling is believed to result from tensile stresses developed in the salt after mining. After the salt spalls, a more favorable pillar geometry forms and further tensile stresses were not predicted [Hoffman and Ehgartner, 1996]. The ability of the finite element models to simulate the subsidence rates during oil fill and drawdown suggests that the deformation mechanism is controlled through creep. During oil drawdown, mine pressure returned to its previous atmospheric level and no increase in subsidence was noted beyond that predicted. As the mine was brine filled, support was reestablished on the pillar and roof surfaces. The added pressure was expected to decrease the subsidence rate to the magnitude of that previously measured when the mine was full of oil. The known pressure-dependent mechanisms (elasticity, creep, and damage) should have decreased the subsidence rate to approximately $0.03 \mathrm{ft} /$ year. However, the subsidence rate increased. This suggested that another mechanism was controlling salt deformation and hence subsidence.

The increased subsidence rates over the Weeks Island mine possibly can be explained by the moisture introduced to the salt as a result of brine fill. Moisture is known to increase the ductility and creep of salt, in some cases by orders or magnitude. The mechanism, although well quantified in the laboratory and through field observations, is difficult to model. It is difficult to predict how long the measured subsidence rates will remain above those predicted using the stress-based models. Case studies on flooded mines, such as those at Belle Isle and Jefferson Island, show that within years, the measured subsidence rates reduce to those predicted by stresscontrolled creep models.

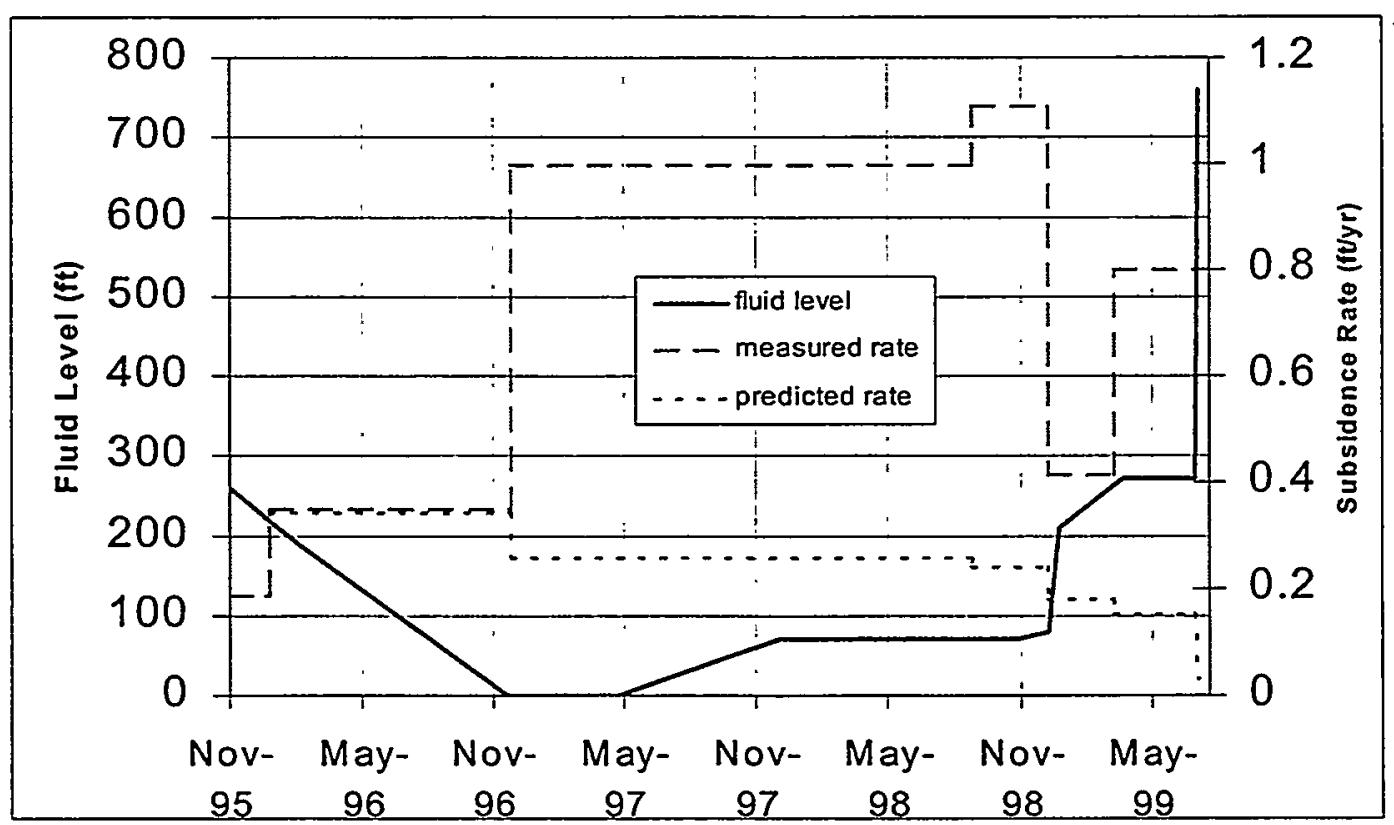

Figure 4.7 Relationship Between Subsidence and Fluid Level in the Mine 


\section{CONDITIONS IN THE SPR MINE}

\subsection{Drawdown Method}

In the late-1994 to early-1995 timeframe, the DOE Weeks Island Mine Integrity Management Group, WIMIMG, considered various options for relocating the oil inventory to other SPR sites and then decommissioning the Weeks Island facility. Basically these options considered either a sequential drawdown (relocating oil, followed by brine fill of the mine), or a concurrent method (drawdown and relocation of oil, with simultaneous brine fill).

The Weeks Island SPR mine was originally designed for sequential oil drawdown. The mine storage levels were graded during original conversion activities (refer to Section 3 ) to drain oil to the bottom of the sump area in the Service Shaft, where the oil booster pumps were installed. With the sequential method, all the flowing oil could be removed through the booster pumps. After pumping drawdown, there would be residual oil in the mine resulting from oil clinging to the salt surfaces, from entrapment in crushed or rubblized salt remaining in the facility, and oil trapped in localized salt surface irregularities. Oil clinging to salt surfaces, and some of the oil trapped in salt pockets, would be washed down by the subsequent brine filling, and then be skimmed for recovery. This method permitted drawdown procedures in a manner with which site operations personnel were familiar, since oil had been drawindown a number of times during the life of the oil storage facility.

Under the concurrent drawdown plan, oil would be withdrawn and simultaneously replaced with pumped-in brine. Since the oil floats on the brine, the rising brine level would raise the oil level and oil would be pumped out from the top. However, all but three of the submersible booster pumps were installed at the bottom of the Service Shaft sump. These three pumps had been raised as a precaution against potential sudden, uncontrolled water inflow to the mine. Under the concurrent plan, the remaining pumps would also be raised. However, the casings would have to be shortened or perforated for pump operations at a higher level. The presumed advantage of using the concurrent method of drawdown/brine fill is that it could provide confinement of salt pillars, resulting in marginally greater pillar stability and smaller surface subsidence.

The advantages and disadvantages of both the sequential and concurrent drawdown methods were analyzed, compared, and debated by the WIMIMG. The sequential drawdown method was finally selected as being more appropriate and superior for use at Weeks Island. The sequential method had nominally lower SPR Project costs and would allow complete oil inventory relocation approximately two years earlier than the concurrent method. Details of the selected and used sequential method, including oil drawdown, brine backfill, and oil skimming follow.

\subsection{Recovered and Remaining Crude Oil}

The crude oil storage capacity of the Weeks Island mine has often been stated as approximately 72 to 73 million bbl. The actual oil inventory prior to drawdown initiation, based on crude oil accountability records [Eldredge, 1999], was $72,544,342 \mathrm{bbl}$, as based on the $1 / 4 \%$ (accuracy) site custody transfer meter; ( $1 / 4 \%$ of 72.5 million bbl is $\pm 180,000 \mathrm{bbl})$. The crude oil drawdown plan for Weeks Island [Walk, Haydel, 1996] required removal of as much of this crude oil as is practical and possible using the site's drawdown pumping equipment. This pumping drawdown was initiated on November 8,1995 . Following this drawdown process, further recovery of remaining crude oil was accomplished in four phases, which are linked with the 
filling of the storage chamber(s) with brine and oil skimming, as described in Section 5.2. A detailed summary of the oil removal phases is described in [Neal et al., 1996].

The oil recovery operations were originally expected to capture all but about $20,500 \mathrm{bbl}$, or $0.03 \%$ of 72.5 million bbl of crude in storage at the start of drawdown [Walk, Haydel, 1996]. As such, the DOE conducted an Environmental Assessment study in 1995 to consider and evaluate the risks of environmental impact from abandoning approximately 10,000 to $30,000 \mathrm{bbl}$ of crude oil [DOE, 1995b]. By 1998, based on drawdown and skimming difficulties, it became obvious that these expectations could not be achieved, and that significantly more oil would have to be abandoned. The quantity of recoverable oil (oil floating on brine that could be skimmed) on both the lower and upper oil storage levels of the Weeks Island facility was determined to be far less than initially planned. This was due, primarily because of entrapment of crude oil in crushed salt in the brine-filled storage chamber [Gibson, 1999], as well as to operational difficulties experienced from pumping oil-brine emulsions near the brine surface. Accordingly, the DOE requested that another geotechnical risk assessment study be performed in late 1998 (as the oil drawdown process was in its final phases), to evaluate the potential environmental impacts and risks of abandoning up to 1.5 million bbl of oil in the Weeks Island mine. The results of this risk assessment study [Molecke et al., 1998] are summarized in Section 9.

The total amount of oil actually recovered, including the drawdown volume plus the amounts recovered by skimming in various phases, was $71,074,257 \mathrm{bbl}(98 \%)$, again based on crude oil accountability records (amount abandoned $=1,469,977 \mathrm{bbl} ; 2 \%$ ). The "exact" oil volumes (and thicknesses) recovered at various stages of the drawdown process are listed in Table 5-1. Figure 5.1 summarizes the oil recovery skimming phases, illustrating the mine levels, phases, oil volumes recovered, and dates. The metering on the Phase II, III, and IV skimmed oil was done by barge strapping or tank gauging. The volume numbers are as accurate as possible, within the limits of uncertainty.

The oil left floating in the mine was calculated from the oil thickness and the barrels/ft mine strapping from the brine fill records. These do not have the precision of the oil transferred numbers but are as accurate as possible [Eldredge, 1999].

Multiple mechanisms can be responsible for the long-term entrapment or entombment of residual crude oil in the brine-filled, Weeks Island SPR mine. These mechanisms, in order of importance, follow. Further details about each mechanism are described in [Molecke et al., 1998].

1. Oil entrapment (by capillary forces) in the.crushed or rubblized salt remaining in the mine, or in existing cracks in mine pillars and surrounding salt. Oil retention and release experiments performed at Sandia National Laboratories [O'Hern and Hinkebein, 1999 ] indicated that the amount of this permanently trapped oil in or on salt may vary between $0.8 \%$ and $7 \%$ of the total mass volume of crushed salt in the mine.

2. Oil entrapment in roof salt irregularities or traps in both the lower and upper mine levels.

3. Oil entrapment in the sediments within the leakage features (sinkholes) and above the salt dome. These mined and natural barriers to oil mobility are further enhanced by the geometry of the mine and the man-made bulkhead system within the mine, serving to isolate the oil from the environment as part of the long-term storage system.

The oil volume trapped in rubblized salt left in the mine was calculated simply as the starting crude oil inventory, minus all oil taken out (by drawdown or skimming), minus what was left floating, with some minor crude oil accountability adjustments [Eldredge, 1999], all within the limits of uncertainty. 
Table 5-1 Oil Recovered or Abandoned in the Weeks Island Mine

\begin{tabular}{|c|c|}
\hline \multicolumn{2}{|c|}{ Mine inventory, prior to drawdown $=72,544,342(\mathrm{bbl})$} \\
\hline Recovered: & Abandoned: \\
\hline Drawdown oil volume $=68,869,955$ & Lower Level skimming (I+IB+II): \\
\hline Phase I oil recovery $=584,213$ & Oil thickness remaining $11 / 5$ inch \\
\hline Phase IB oil recovery $=1,146,432$ & Mine volume at level $=1,000,000 \mathrm{bbl} / \mathrm{ft}$ \\
\hline Phase II oil recovery $=459,383$ & Oil remaining in crushed salt $=1,278,729$ \\
\hline & $=125,000 \mathrm{bbl}$, trapped on roof, lower level \\
\hline Phase III oil recovery $=684$ & Upper Level skimming (III+IV) : \\
\hline Phase IV oil recovery $=13,590$ & Oil thickness remaining $13 / 4$ inch \\
\hline & Mine volume at level $=300,000 \mathrm{bbl} / \mathrm{ft}$ \\
\hline & $=43,750 \mathrm{bbl}$, trapped on roof, upper level \\
\hline & Total floating oil $=168,750$ (lower + upper) \\
\hline & Total adjustments $=22,498 \quad[$ Eldredge, 1999$]$ \\
\hline & Oil trapped in crushed salt $=1,278,729$ \\
\hline $\begin{array}{r}\text { Total inventory recovered }=\underset{(\mathbf{9 8 \%})}{\mathbf{7 1 , 0 7 4 , 2 5 7}} \\
\mathbf{( 9 8}\end{array}$ & $\begin{array}{c}\text { Total inventory abandoned }= \\
(2 \%)\end{array}$ \\
\hline
\end{tabular}

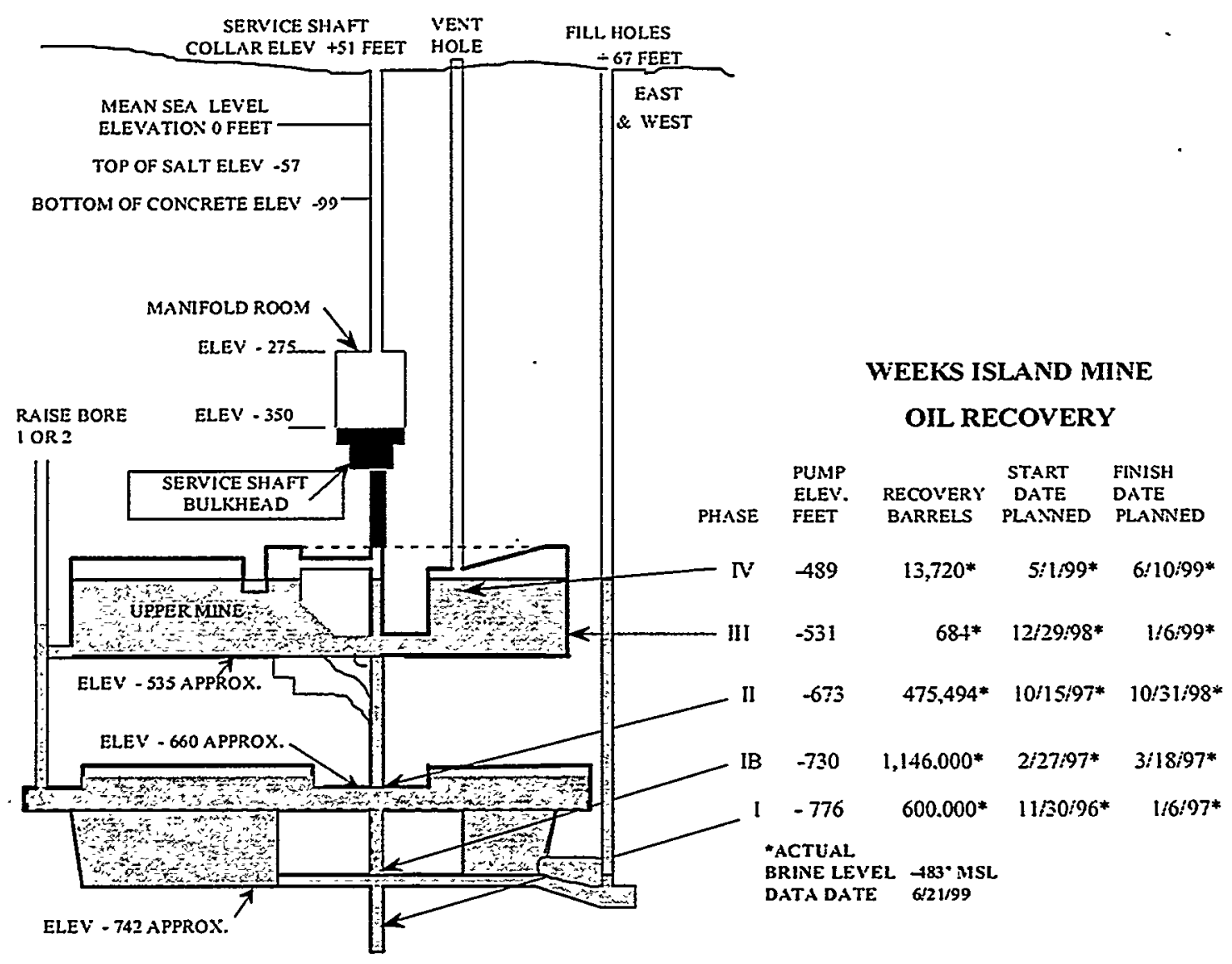

Figure 5.1 Weeks Island Mine Oil Recovery, by Skimming Phase 


\subsection{Brine Backfill and Oil Skimming}

In the process of abandoning the Weeks Island site, following the oil drawdown by pumping, both lower and upper levels of the mine were completely filled with brine, nominally $85 \%$ saturated. The purpose of the brine fill was to minimize further salt dissolution and creep of the surrounding domal salt formation, thereby stabilizing the mine and reducing subsequent surface subsidence (refer to Section 4.3 on subsidence over the facility, and Section 5.4 on creep diminution and mine stability). The brine was supplied to the SPR program under a commercial contract with Sofregaz. Sofregaz developed a brine well in the northeastern quadrant of the Weeks Island dome (refer to Figure 3.1), on Morton Salt property, and supplied the brine to the Weeks Island SPR fill holes at rates of about 200,000 barrels/day.

Ideally, the injection of fully saturated brine into the mine would avoid any dissolution of salt wall and pillar material [Levin, 1998a]. In reality, the initial specific gravity of the brine produced from the Sofregaz brine cavern was well below saturation since raw water was injected into that cavern as part of the dissolution process of producing brine and expanding the cavern volume. The cumulative final weight percentage of salt in solution established under the brine production contract was $85 \%$ or more of the salt that would be in saturated brine. Saturated brine has a specific gravity of approximately 1.2. It was originally thought that a final cumulated specific gravity of the injected brine of 1.18 or greater would have to be attained to meet the terms of the contract. Further analysis of weight percentage of salt and density of sodium chloride solution properties as a function of temperature showed [Levin, 1998a] that a final specific gravity of 1.17 for the accumulated injected brine more than exceeded the weight percentage criteria of the contract.

Brine fill of the Weeks Island mine started on November 8, 1996, exactly one year to the day after oil drawdown was initiated. Residual crude oil on the floor of the lower mine floated upward and was skimmed in phases. Existing crude oil booster pumps in the Service Shaft were used to skim the floating oil from the lower mine in Phases I and IB. Additional brine was added and the oil level brought up near the roof of the lower oil storage chamber. Then, new skim pumps were used to skim oil at that level, in Phase II.

Due to mine roof survey-data discrepancies, too much brine was initially added for successful skimming at this level. The excessive brine fill isolated the oil at the pumps' location in the Service Shaft, apparently due to lower drift ceiling heights leading to the pumps. Eight hundred thousand barrels of brine were removed from the mine between February and August 1998. Skimming then continued until November 1998 when brine fill resumed. High-brine content, viscous oil emulsions caused some pumping difficulties in much of the oil skimming process. To help mitigate the emulsion difficulties, addition of a very fast-acting, chemical emulsion control agent was tried. Throughout the oil skimming phases, technical difficulties encountered slowed the skimming progress to only a fraction of that originally envisioned, with oil recovery costs far exceeding product value. The falling off of skimming rates in Phase II oil skimming operations would have required the extension of skimming operations by years in order to recover a volume of skimmable oil dwarfed by the amount of oil permanently entrapped in crushed salt beneath saturated brine [Gibson, 1999]. Accordingly, DOE made a programmatic decision to expedite the filling of the oil storage chamber with brine, in October 1998, thereby terminating Phase II skimming operations. This decision was based both on recovery cost economics and the desire to more quickly enhance the partially empty mine stability; this decision was supported by the 1998 
risk assessment study, summarized in Section 9. The Department's decision was formally communicated to the public in a Press Release dated November 24, 1998.

The volume of brine added to the mine as a function of time (date) is shown in Figure 5.2. The level of the brine versus mean sea level (MSL) as a function of time (date) is similarly shown in Figure 5.3. The periods of no brine fill, as indicated by near-horizontal lines on the plots, are periods of oil skimming or brine removal.

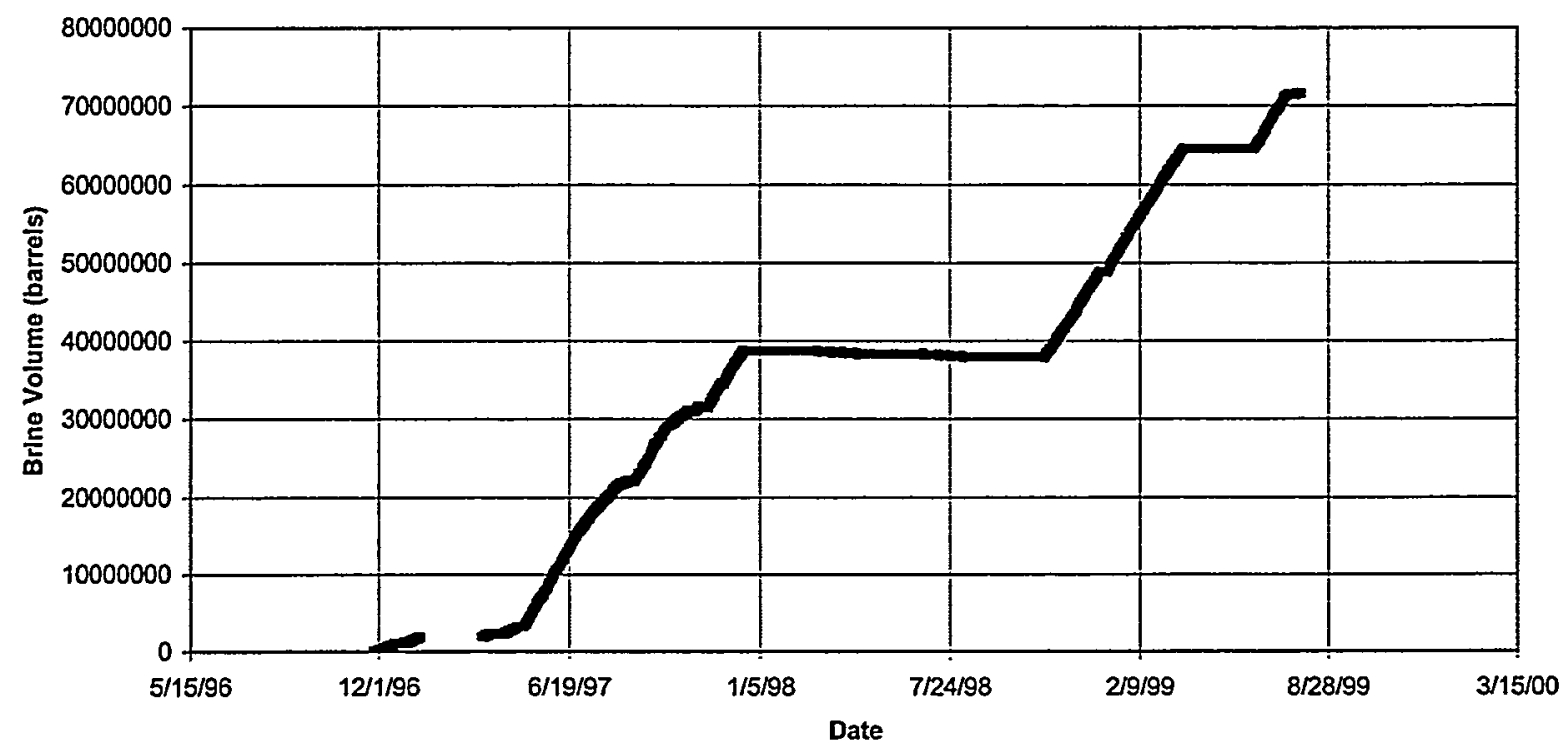

Figure 5.2 Weeks Island Mine Brine-Fill Volume vs. Time

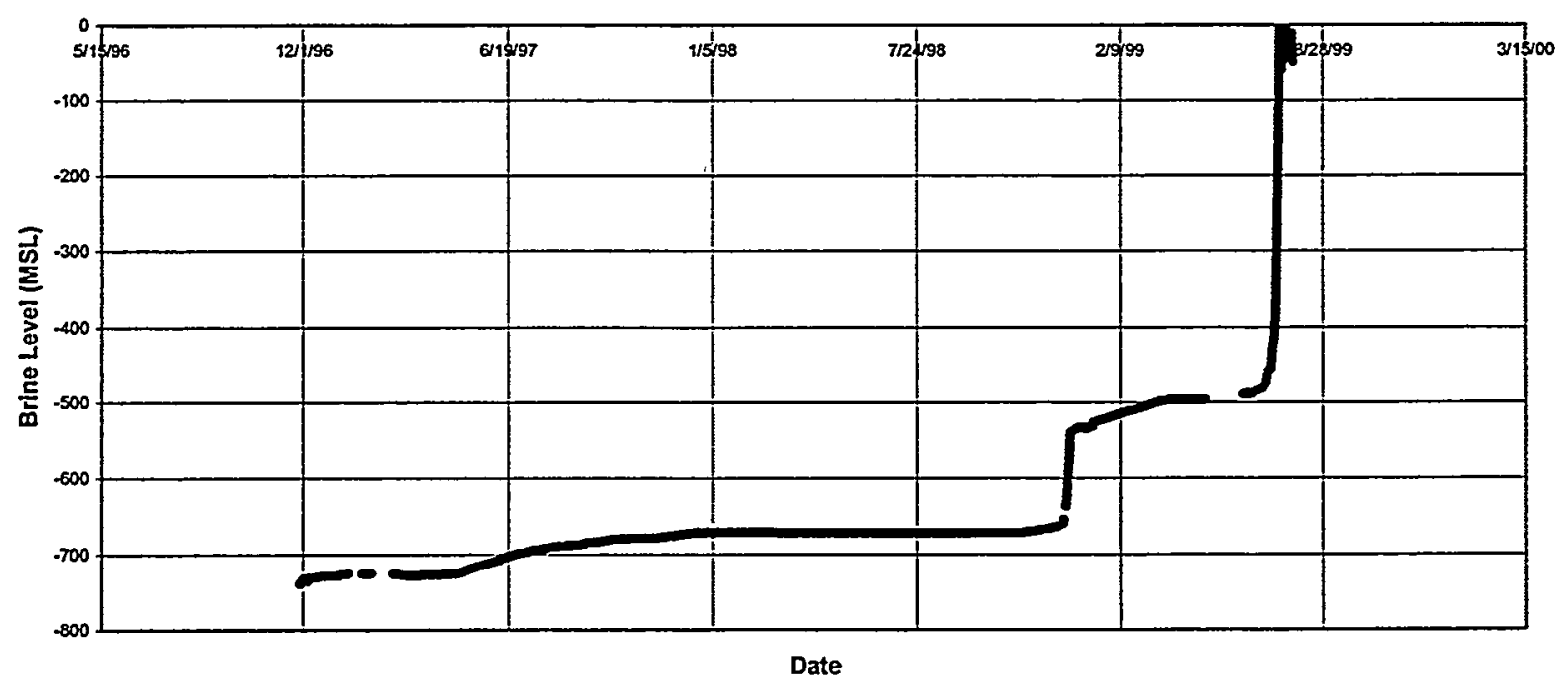

Figure 5.3 Weeks Island Mine Brine-Fill Level vs. Time 
There was a brief attempt to skim residual oil at the bottom level of the upper mine in January 1999, during the Phase III skimming. Brine fill then continued until April 1999. The final phase of skimming, Phase IV, was accomplished from a skimming pump installed in the vent hole (refer to Figure 5.1); Phase IV was started on April 15, 1999 and was completed June 10, 1999. The final phase of brine fill started June 10, 1999 and was completed on July 19, 1999; this completion is clearly visible in Figure 5.3. Minimal amounts of fresh water were injected into the fill holes, and brine was injected at well EH-3, during August, September and October 1999. These injections maintained the fluid level in the mine during both the plugging of the surface wells into the mine (refer to Section 7.1) and the installation of the long-term monitoring system in the East Fill hole (refer to Section 8.1).

\subsection{Creep Diminution and Mine Stability}

The brine fill of Weeks Island and connection to the aquifer through the East Fill Hole established hydrostatic pressure throughout the mine. The back pressure exerted on the mined surfaces improves stability and slows salt creep and hence reduces the rate of subsidence.

Several numerical models have predicted the response of the Weeks Island mine to brine fill. A 3-D model by Hoffman [1994a] investigated a decommissioning option where the mine was pressurized with brine from the bottom of the fill holes up to the manways to facilitate removal of oil from the upper portion of the mine. The pressures under this scenario are slightly less than those expected for a brine-filled mine at hydrostatic pressure, but can serve as a high estimate for creep and subsidence. The analyses predicted a reduction in subsidence and mine closure rates to approximately $10 \%$ of those for an oil-filled mine. The average annual maximum subsidence rate prior to decommissioning activities was approximately $0.18 \mathrm{ft} /$ year (average, from 1990-1994) with a corresponding closure rate of 160,000 bbl/year [Ehgartner, 1999]; refer also to Section 4.3 for actual subsidence rate measurements. Thus, the predicted subsidence and closure rates for a brine filled mine are smaller than one-tenth of these values since the analysis was based on mine fluid pressures smaller than hydrostatic. Two types of salt damage were predicted prior to decommissioning. Tensile fracturing and dilatancy (microfracturing) were predicted in the pillars and in an area along the top of salt overlying the edges of the mine. After hydrostatic pressurization, the stress state in these areas improved suggesting that pillar stability would improve and cracking along the top of salt would cease.

A similar 3-D finite element model was used to predict the long-term response of a brinefilled mine at hydrostatic pressure [Hoffman and Ehgartner, 1994]. This analysis simulated a brine head to the water table. Predictions of future subsidence, stability, and the potential to develop new fractures in the overlying salt were estimated along with the quantity of brine that may seep from the mines. After decommissioning, the volumetric closure rates and subsidence rates were predicted to reduce to approximately $5 \%$ of the rates prior to decommissioning. Mine stability was improved. Figure 5.4 shows the dilatant damage (contours greater than 1; microfracturing is possible when damage potentials exceed a value of 1.0) predicted in the pillars and along the top of salt prior to decommissioning when the mine was oil filled. With the application of hydrostatic brine pressure in the mine, a significant improvement is predicted for the pillars as shown in Figure 5.5. Although some damage is still predicted along the top of salt after brine fill of the mine, the areal extent and magnitudes are decreasing with time, suggesting that new fractures should not develop. Based on the measured subsidence rates (refer to Section 4.3) and closure existing during the time the mine was filled with oil, the post-closure subsidence rate was 


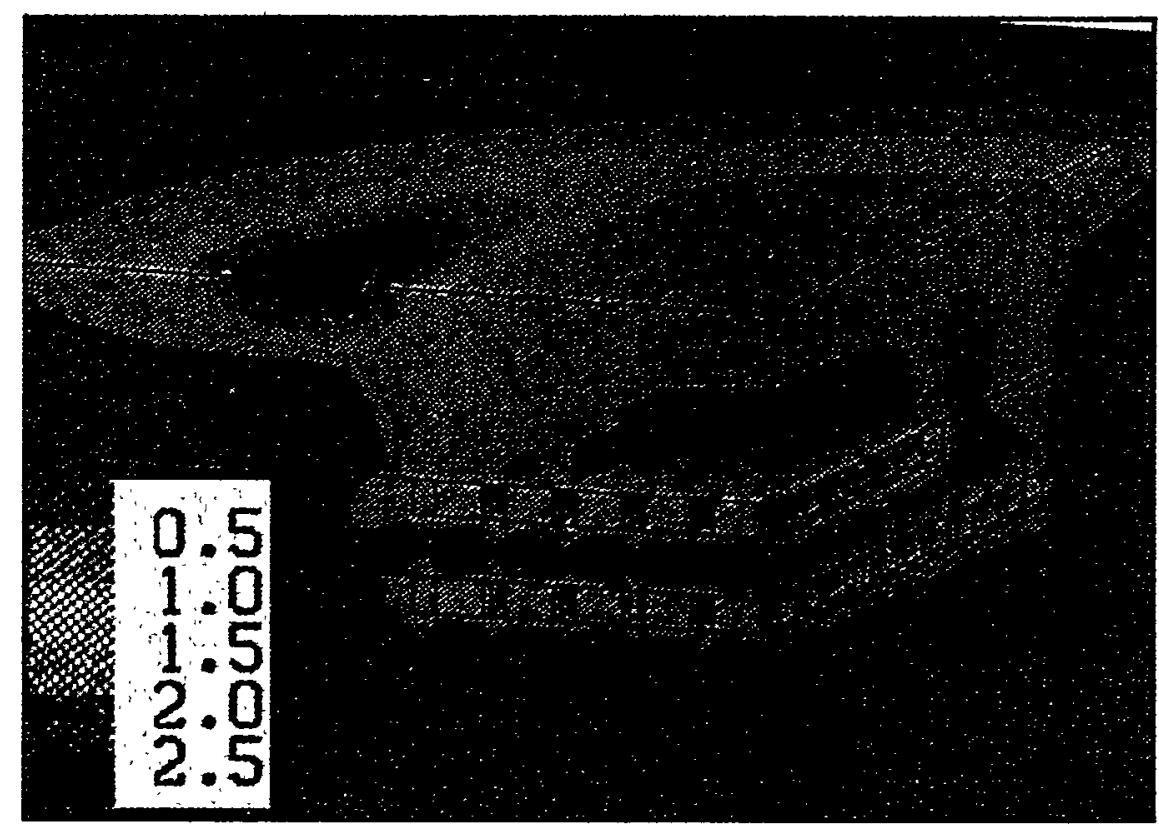

Figure 5.4 Predicted Potentials of Salt Damage Prior to Decommissioning an Oil Filled Mine

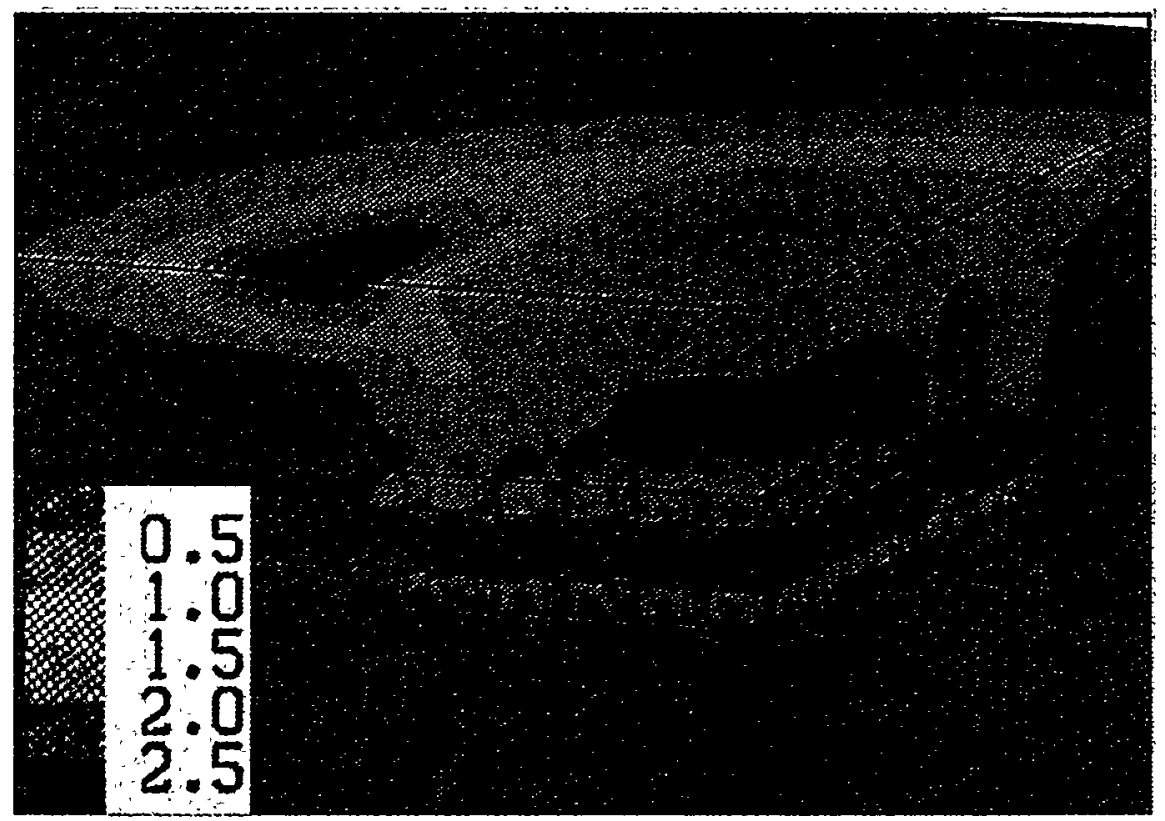

Figure 5.5 Predicted Potentials of Salt Damage After Decommissioning for a Brine Filled Mine at Hydrostatic pressure

estimated at $0.006 \mathrm{ft} / \mathrm{year}$, which is less than the geologic domal uplift rate, believed to be 0.008 ft/year [Acres, 1987]. The modeling results [Hoffman and Ehgartner, 1994] also indicated that after closure, brine would be discharged into the overburden at a rate of approximately $12 \mathrm{gal} / \mathrm{hr}$ $(2,500 \mathrm{bbl} /$ year $)$. Further, mine stability would be improved after decommissioning because of 
increased pillar confining pressures. Hence, the analysis results showed improved long-term conditions by brine filling the mine after oil removal.

Additional studies using empirical and 2-D creep models of the mine were used to predict subsidence rates and salt stresses after decommissioning [Van Sambeek et al., 1994]. The modeling suggested that closures rates would reduce to $8 \%$ of the magnitude for oil-filled mine and predicted favorable stresses from a structural point of view. The study also included several case studies of flooded salt mines. Inadvertent flooding of the Jefferson Island Mine with fresh water from Lake Peigneur resulted in post-flooding subsidence rates measured at approximately $12 \%$ of the pre-flood values. Intentional flooding of the Belle Isle Mine with freshwater resulted in post-flood subsidence rates of about $5 \%$ of the pre-flooding rates. These rates agree with the predicted rates presented above.

In summary, the decommissioned, brine-filled Weeks Island mine closure and subsidence rates were estimated to be less than $5 \%$ of those measured during the time when the mine was oil-filled. A favorable stress state was predicted from a stability point of view as a result of brine fill of the mine to hydrostatic pressure.

\subsection{Markel Wet Drift, Leakage and Grouting}

The earliest history of the Markel Wet Drift, starting in December 1977, has been previously documented [Acres, 1987] and was briefly described in Section 3. The leak rate in the Markel Wet Drift (refer to Figure 3.2) increased dramatically by late 1978 to 200 gph, and in some cases higher, before being decreased to less than 2 gallons per hour by chemical grouting. Wet Drift inflow began to increase again between 1981 and 1984 to approximately $5 \frac{1}{2}$ gallons per hour. Further grouting in the Markel Wet Drift roof and in leak paths around the Markel bulkhead were conducted during this time period. The inflow at the end of grouting was reported to be less than 1 gallon per hour.

In the time period from 1986 and 1998, there were several significant grouting operations in the Markel Wet Drift. Grouting operations took place in 1992, 1994, and 1995. These operations targeted relatively small leaks in the roof of the drift. Periodic monitoring of leak rates in the Markel Wet Drift, plus adjacent Kolbas and Lark drifts, continued during this time.

The 1994 operation that took place in the Markel Wet Drift was designed to drill fans of holes axially over the drift and down the ribs to recreate the curtain developed by Cementation during 1981. The curtain was being developed from the face of the drift toward the bulkhead. During grouting operations, two holes, both in the North rib of the drift, hit significant flow. The flow rate from the two holes was approximately $20 \mathrm{gpm}$, each. Difficulties occurred during the grouting of these holes. Following completion of the first part of the shield grouting, operations were discontinued. Inflow was significantly impacted by this operation.

The 1995 operation targeted previous leak sources identified by review of previous grouting operations in the Markel Wet Drift. In 1998, brine inflow was again observed to increase. Figure 5.6 summarizes the most recent brine inflow to the Markel Wet Drift as a function of time, in 1998 and early 1999. The grouting program consisted of 8 long (120 ft) holes drilled from the Kolbas Drift that were targeted to intercept known leak sources above the drift. During the drilling three holes hit significant inflow with rates between 2 and $27 \mathrm{gpm}$. These holes were grouted, again impacting the leakage into the drift. 


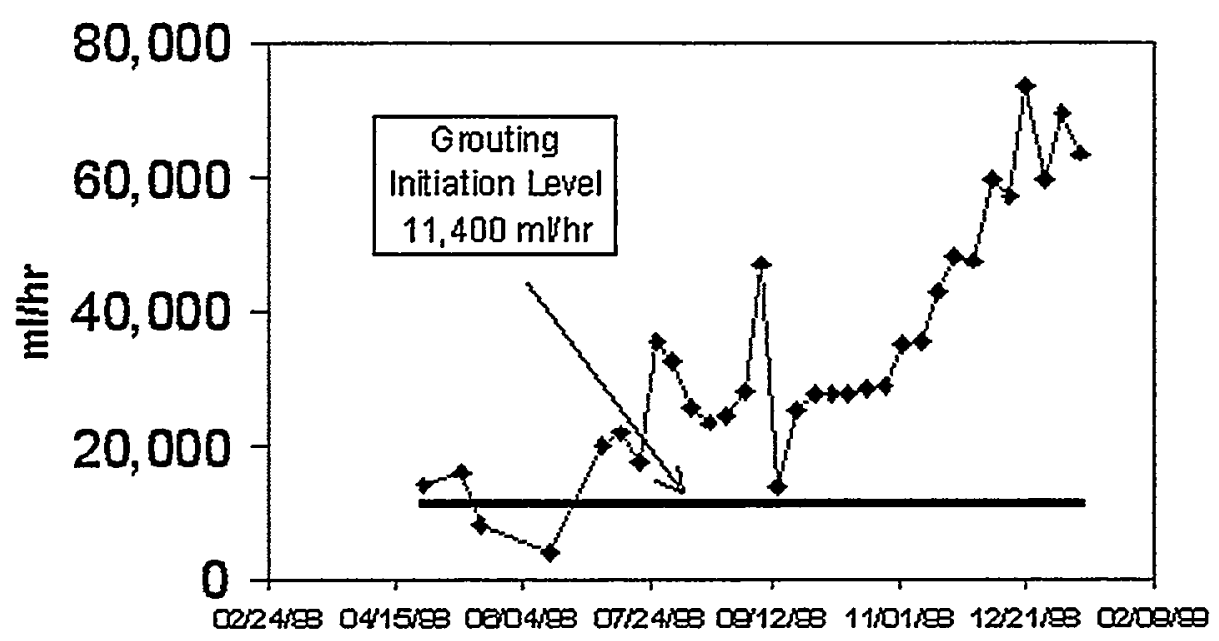

Figure 5.6 Markel Wet Drift Recent Brine Inflow History

During the time period from 1986 through 1997 monitoring of the Markel Wet Drift was accomplished by measuring ceiling leaks. Little is known about the total inflow into the Markel Wet Drift sump during this time period. No systematic attempt was made in this period to measure total accumulation in the drift sump.

In April 1998, the Weeks Island Cavern Engineer performing the weekly mine inspection began noticing that the volume of brine pumped from the sump in the Markel Wet Drift seemed to be significantly larger than the volume accounted for in leakage from the roof of the drift. At this time, attempts were made to better quantify the brine volume pumped on a weekly basis. However, due to operational conflicts with the ongoing crude oil inventory relocation, it was extremely difficult to obtain reproducible pumped volumes.

By July 1998 it was apparent that something new had to be done to obtain reproducible leakage rates. Consequently, site maintenance was tasked with installing a flow meter and line to pump brine directly from the Markel Wet Drift sump into the Weeks Island mine via Raisebore \#1. During this time period it became apparent that there was a mass balance problem between the volume pumped and the volume accounted for in estimates of leakage from the mine roof.

In late July 1998, Rembco Engineering recommended attempting to isolate roof leakage on top of the drift floor by covering it with visquene and damming the front of the drift behind the sump. The trapped brine could then be measured as the total leakage from the roof of the drift. Additionally, Rembco recommended putting an individual collector under the largest roof seep in the drift to quantify its volume directly also.

DynMcDermott updated the Department of Energy on these findings in mid September 1998. Reproducible pumping volumes were obtained by mid August 1998 and the trapping system recommended by Rembco was operational by late September 1998. Early data indicated that only $10 \%$ of the brine leakage into the drift could be accounted for by ceiling leaks.

In mid-September 1998, DynMcDermott requested that Rembco Engineering evaluate the leakage in the Markel Wet Drift and provide their recommendations. Recommendations were to address the question of what actions should be taken should the DOE remain at Weeks Island for 
one year and another recommendation for ten years. These recommendations were transmitted to the Department of Energy in early October 1998 along with recommendations to revise the existing grouting criteria due to the impending decommissioning of the Weeks Island facility. In addition, Magorian [Magorian, 1998] also recommended that continued grouting in the Markel Wet Drift may be the best bet, despite its poor prognosis, to keep the manways open for another year or more, as long as there was a continuing requirement for access. He stated that pressurizing with brine was a fallback position in the event that grouting is unsuccessful, to buy a little time to complete necessary underground activities.

The Wet Drift continued to leak at an increased rate. On November 10, 1998, DynMcDermott mobilized Rembco Engineering Inc. to active status on the Standby Grouting Contract for grouting in the Wet Drift. The intent of this grouting program was to perform sufficient investigations in the drift in order to allow a targeted response to the situation. Prior to grouting initiation, Rembco Engineering scaled the area around the two significant roof point sources in the drift. These two leaks had been increasing in quantity and it was speculated that the leakage into the floor may have been from these leaks, down inside the salt bloom, and onto the floor. These drips were scaled and inspected from scaffolding and indicated no significant leakage had been occurring down the back of the bloom. The two holes were drilled out and an unsuccessful attempt to inject grout followed.

A second part of the Markel Wet Drift investigation involved scaling a strip down the North rib of the drift with the intention of determining whether brine was leaking behind the bloom down the ribs of the drift. The strip was essentially dry.

The third part of the investigation involved cutting trenches through the floor to hard salt, to isolate any floor leakage to the portion of the drift where it was coming in. Inflow data implied that the majority of the flow was in the bloom area forward toward the bulkhead. This information implied that the leak was indeed inside the rib of the drift and down onto the floor of the drift. Consequently, a grouting plan was developed and initiated to drill angled holes from the Kolbas Drift up over the top to the Markel Wet Drift. The holes were targeted to intersect the anticipated strike of the leak feature.

All of the holes were surveyed in by a licensed mine surveyor and holes were drilled to depths of as much as $160 \mathrm{ft}$. The anticipated leak feature was intercepted in every hole at approximate depths predicted by previous analyses. Inflows from the holes were between 5 and 20 gallons per minute.

Holes were drilled in groups, then grouted with ultrafine cement. Following hardening of the ultrafine, the holes were re-drilled and grouted with acrylamide. The holes were then drilled out again in preparation for lengthening. It was anticipated that some of the holes would again hit the leak feature. The leak feature was turning toward the face of the drift and it was believed that the banding of the salt in the drift indicated that the leak zone would cross in front of the wet drift. The plan was to drill holes until the intercept at the face was encountered and grout the second leak zone. The decision was made by the SPR Project Manager that the initial grouting success was adequate to allow safe decommissioning of the facility. Grouting ended with the abandonment of all grout holes by drill-out of the acrylamide and cementing back with a thick cement slurry.

As part of the overall Weeks Island mine decommissioning process, the Markel Wet Drift was filled with brine in July 1999 , thereby ending its long and periodic problematic existence. 


\section{CONDITIONS IN THE MARKEL MINE}

The Markel Mine was developed by the Morton Salt Company while the Weeks Island Mine was being converted by the DOE for oil storage. Development of the Markel Incline and the access drift that became known as the Markel Wet Drift are described briefly in Section 3. New accessways for development of the Markel Mine, to replace the Markel Wet Drift, were excavated without encountering any major seepage. These access drifts were called the Johnston and Sandrik drifts (refer to Figure 3.2). As Morton continued development of the interim Markel Mine, conversion of the old mine workings for SPR use proceeded between 1978 and 1979. The Markel Mine was mined for salt by Morton through 1980, then abandoned. No maintenance or ventilation changes were made to this mine since its abandonment. During the Markel Mines' two years of operation, Morton produced in excess of 1.9 million tons of salt. It was mined by the room and pillar method with 75-ft high, 50- to 70-ft wide room sizes (refer to Figure 3.3).

Since it's abandonment, the Markel Mine posed potential risks to the operational Weeks Island SPR mine. One risk of the Markel was associated with its large volume serving as a reservoir that could allow a leak in the SPR underground access manways and shafts to become uncontrollable. Another risk was from an unknown or uncontrolled leak developing in the Markel Mine, yielding flooding of the SPR manways and, or, inability to drawdown (prior to decommissioning) [Molecke, 1997]. The magnitude of these risks was never quantified due to lack of adequate geotechnical data. As such, since its abandonment, the Markel Mine was periodically inspected for possible signs of instability [Hoffman, 1994b]. SPR weekly monitoring of the Markel Mine began in 1985, but was terminated in 1987 when Morton declared the Markel unsafe to personnel. As a result, Boeing Petroleum Services (predecessor to DynMcDermott Petroleum Services) placed the Markel Mine "off limits" to their personnel and contractors. This loss of access and inability to inspect the Markel resulted in a perceived increased risk to the SPR, since potential leaks would be unknown and could become uncontrollable. Several inspection and monitoring plans, plus options, were proposed to DOE in 1987, if access was regained. This led to construction of the Sandrik and Johnson drift isolation bulkheads in 1992, essentially sealing off the Markel Mine from the SPR mine (refer to Figure 3.2).

Previous inspections of the Markel Mine were conducted by Sandia National Laboratories (Acres) in 1984, 1987, 1988, 1989, and 1990 [Acres, 1987; Williams, 1997]. Several inspections were also conducted by PB-KBB. In 1992, an inspection was conducted of the unbenched-area perimeter by the Mine Safety and Health Administration, DOE SPR, and SNL. These earlier inspections showed that the Markel Mine had undergone progressive deterioration, as evidenced by spalling and slabbing pillars. No significant areas of mine instability were noted and roof falls were minor. Further details of these inspections are summarized separately [Williams, 1997].

\subsection{Final Markel Mine Inspection}

Representatives of Sandia National Laboratories (SNL), its contractors, Acres International Corporation (Acres), J.T. Neal, and Department of Energy Strategic Petroleum Reserve conducted the final walk-through inspection of the upper perimeter of the Markel Mine on June 25, 1997 [Williams, 1997]. Williams reported that the purposes of the inspection were to:

- assess the current condition of the mine by inspection of pillars, walls, and ceilings where possible; 
- inspect for leaks, locate and measure depth of existing brine pools; and

- document the condition of the mine with a photographic record.

The inspection team spent approximately 5.5 hours underground to complete the survey and to document the condition of the mine with 120 photographs. Morton Salt personnel have also conducted several (separate) inspections of the Markel Mine in the last several years, but no documented observations or conclusions have been made available.

The Markel Mine has undergone very gradual deterioration since the last prior inspection. No drips or seeps were observed. While the brine volume has generally receded, there was some standing brine in very shallow (2- to 3-inch deep) pools. The brine monitoring station in the East Slant had dried and other areas of the mine also showed this same trend in the reduction of the brine volume. This reduced brine volume was probably due to ventilation, with air-drying. The only place where increased brine volume was possibly noted was in the Dead End decline, where ventilation was minimal because of the confined space.

Relatively few new salt falls (seven), in corners or from the ceiling, were noted in the perimeter. The September 1989 inspection indicated that salt falls from pillars in the 90 -ft benched area, and 25-ft pillars in the upper bench, had shifted to the northern rib. This shift in salt falls to the northern rib was still evident as all the new falls were in the northwest perimeter. Observers were not able to determine the extent of new falls in the benched area since they did not enter this area. However, photographs of these areas were taken from the berms in the upper perimeter. These areas showed little degradation from the previously documented inspection in 1989.

In summary, the deterioration of the Markel Mine had been very gradual since the last inspection. No major changes were noted in either the upper or the benched areas. Overall, the brine volume was diminished, probably as a result of evaporation from the existing mine ventilation. No seeps or drips were active during the observation time. What brine was observed may be residual from earlier connate seeps, or it could be from extremely slow seepage. Considering the mine has had virtually no maintenance since 1980 , it was in surprisingly good condition at that point in time. The shallow depth of the Markel was probably the reason for the small amount of observed creep-induced deterioration.

\subsection{Final State of the Markel Mine}

In parallel with the Weeks Island mine decommissioning process, the Morton Salt Company decided to brine fill the Markel Mine, for purposes of achieving long-term geologic stability. Morton Salt began the Markel Mine brine-fill operations on April 12, 1999, using one pump at an initial rate of $80,000 \mathrm{bbl}$ per day. The brine, from the Sofregaz brine well in the northeastern quadrant of the Weeks Island dome, was the same as that used to fill the SPR mine. Within several weeks, the Markel brine-fill rate was increased to $210-230,000 \mathrm{bbl} /$ day. This brine was brought in by piping down the SPR Production Shaft, through the Weeks Island manways, down the Johnston drift and through the Johnston bulkhead (refer to Figure 3.2), then into the Markel. When brine fill was within $5 \mathrm{ft}$ of the roof, Morton reconfigured the fill to pass through a 6-in diameter line through the bulkhead. Morton completed filling the Markel Mine on:June 9, 1999, after a few delays, and after about 7.9 million bbl of brine had been added.

Morton then drilled a relief hole (well) into the Markel Mine from the surface, in order to be able to add the last amount of brine needed to bring the mine to hydrostatic pressure, as well 
as to release the trapped air space. The drilled relief well deviated somewhat and penetrated a salt pillar in the Markel rather than void space; it was then successfully redrilled. The Markel Mine was brought to hydrostatic pressure in August 1999, with the addition of about 0.6 million $\mathrm{bbl}$ of brine; a total of approximately 8.5 million bbl of brine were used to fill this mine. 


\section{DECOMMISSIONING ACTIVITIES}

The decommissioning plan [PB-KBB, 1996] to plug and permanently abandon the Weeks Island facilities in a safe and acceptable manner after oil drawdown included, basically:

- filling the storage caverns with $85 \%$ (nominal) saturated brine (details in Section 5.3);

- plugging and abandonment (P\&A) of underground bulkheads;

- P\&A of wells, fill and vent holes;

- P\&A of the Production and Service Shafts;

- demolition and removal (D\&R) of salvageable downhole equipment, including pumps;

- decommissioning of surface facilities;

- covering underground openings;

- limited surface re-grading; and,

- general site cleanup.

Summary details for Weeks Island decommissioning tasks were initially described in [Neal et al., 1996]. Newer details on the recently accomplished plugging and abandonment or demolition and removal activities are described in the following Sections.

\subsection{Underground Bulkheads}

During the initial conversion of the mine to oil storage operations in the late 1970's, a total of five concrete underground bulkheads were constructed at various locations within the mine, as shown on Figure 7-1. A total of 24 casings ranging in size from 4 to 24 inches in diameter penetrated these five bulkheads into the former oil storage levels. The casings had been used primarily for oil fill and removal as well as for monitoring, inert gas injection, and gas venting. The Service Shaft Manifold Room contained the greatest number and largest casing diameters and was the main point of oil movement into and from the mine. In the early 1990's, the Service Shaft and both Raisebore bulkheads were reinforced by the addition of approximately $50 \mathrm{ft}$ of high-strength, epoxy-cement grout below the existing bulkheads [Ehgartner, 1991]. All the bulkheads were in good, operational condition prior to decommissioning. Other than plugging the bulkheads, described below, and closing the bulkhead doors between the Markel mine and the Weeks Island manways, no significant efforts was performed prior to flooding the manways.

The overall objective of the subsurface decommissioning and casing plugging and abandonment (P\&A) was to completely confine the oily film floating above the brine fill to the mine storage levels, and to protect the environment from potential contamination. To fulfill this objective, the bulkhead casings were cleaned, a bridge plug installed, a cement plug installed above the bridge plug, and a cap welded to the exposed end of the casing. Table 7-1 is a summary of the relevant data for bulkheads and casings for the decommissioned mine.

Bulkhead casing P\&A was accomplished during various schedule phases of mine brine fill and oil skimming operations, when the mine was still subject to vapor pressure fluctuations. In addition to the exhaust blowers and flare connected to the former storage levels, vapor relief was provided at two bulkheads. The Markel 24-inch casing and Production Shaft 6-inch casing, shown in Figure 7-2, were fitted with bridge plugs with a central relief system. The relief pipe was connected to the mine exhaust system and to the flare. After brine fill of the mine, P\&A of 


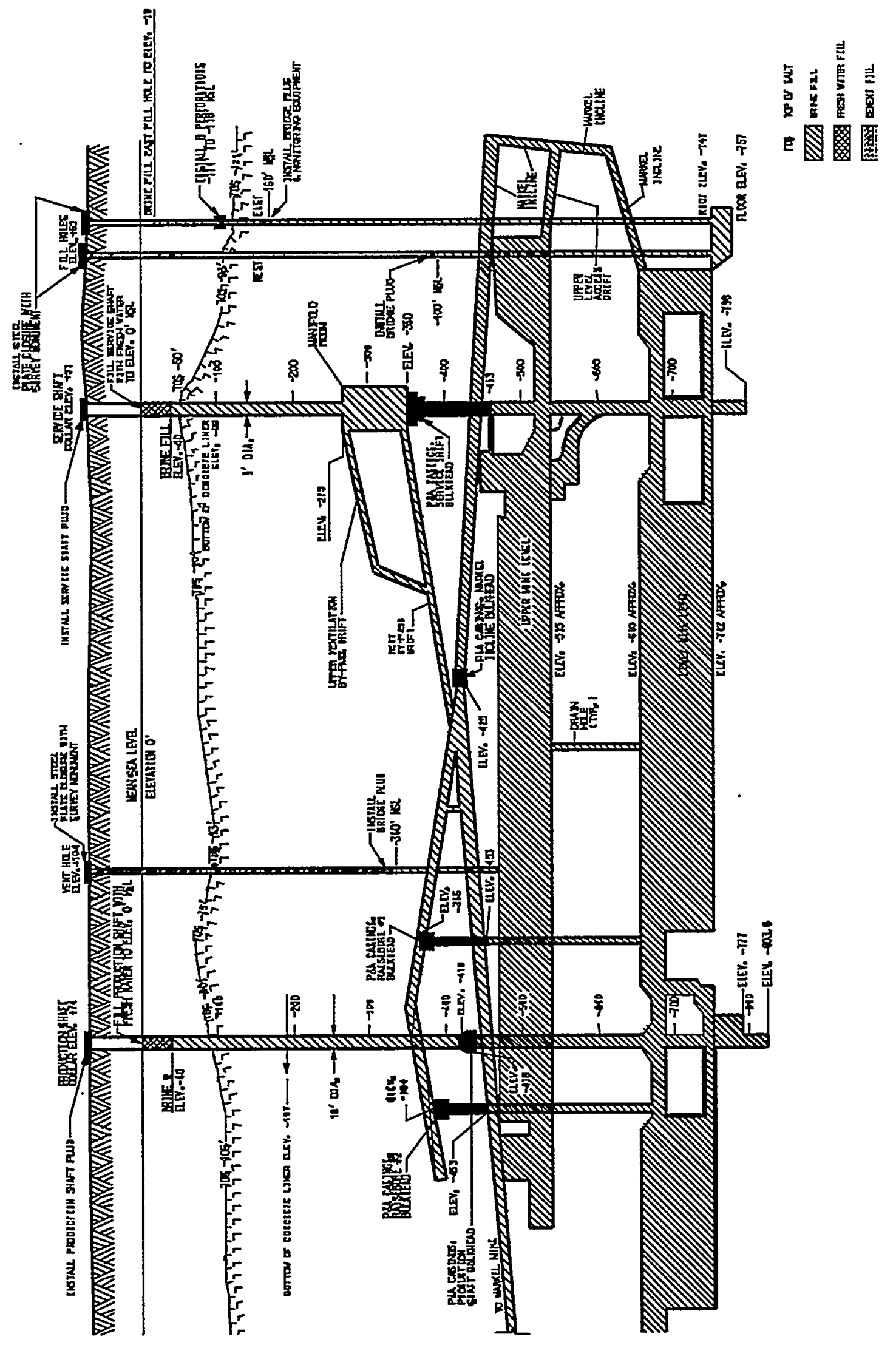

Figure 7.1 Weeks Island Mine Profile Schematic 
Table 7-1 Underground Bulkhead Data

\begin{tabular}{|c|c|c|c|c|}
\hline Location & $\begin{array}{l}\text { Bulkhead } \\
\text { Thickness }\end{array}$ & $\begin{array}{c}\text { Number of } \\
\text { Casings }\end{array}$ & $\begin{array}{c}\text { Top of Bulkhead } \\
\text { Elevation }\end{array}$ & $\begin{array}{l}\text { Bridge Plug Set- } \\
\text { ting Elevation }\end{array}$ \\
\hline $\begin{array}{l}\text { Production } \\
\text { Shaft }\end{array}$ & $20 \mathrm{ft}$ & $\begin{array}{l}1-12 \text { inch } \\
1-6 \text { inch }\end{array}$ & $-418 \mathrm{ft} \mathrm{MSL}$ & $-438 \mathrm{ft} \mathrm{MSL}$ \\
\hline $\begin{array}{c}\text { Service } \\
\text { Shaft }\end{array}$ & $103 \mathrm{ft}$ & $\begin{array}{c}1-24 \text { inch } \\
12-18 \text { inch } \\
4-6 \text { inch } \\
2-4 \text { inch }\end{array}$ & $-350 \mathrm{ft} \mathrm{MSL}$ & $-380 \mathrm{ft}$ MSL \\
\hline Raisebore \#1 & $88 \mathrm{ft}$ & 1-4 inch & $-365 \mathrm{ft} \mathrm{MSL}$ & $-390 \mathrm{ft} \mathrm{MSL}$ \\
\hline Raisebore \#2 & $69 \mathrm{ft}$ & $1-4$ inch & $-384 \mathrm{ft} \mathrm{MSL}$ & $-409: \mathrm{ft} \mathrm{MSL}$ \\
\hline $\begin{array}{l}\text { Markel } \\
\text { Incline }\end{array}$ & $20 \mathrm{ft}$ & $1-24$ inch & $\begin{array}{l}\text { Horiz. Bulkhead } \\
\text { @ - } 425 \mathrm{ft} \text { MSL }\end{array}$ & $\begin{array}{l}\text { Horiz. Casing } \\
20 \mathrm{ft} \text { inside }\end{array}$ \\
\hline
\end{tabular}

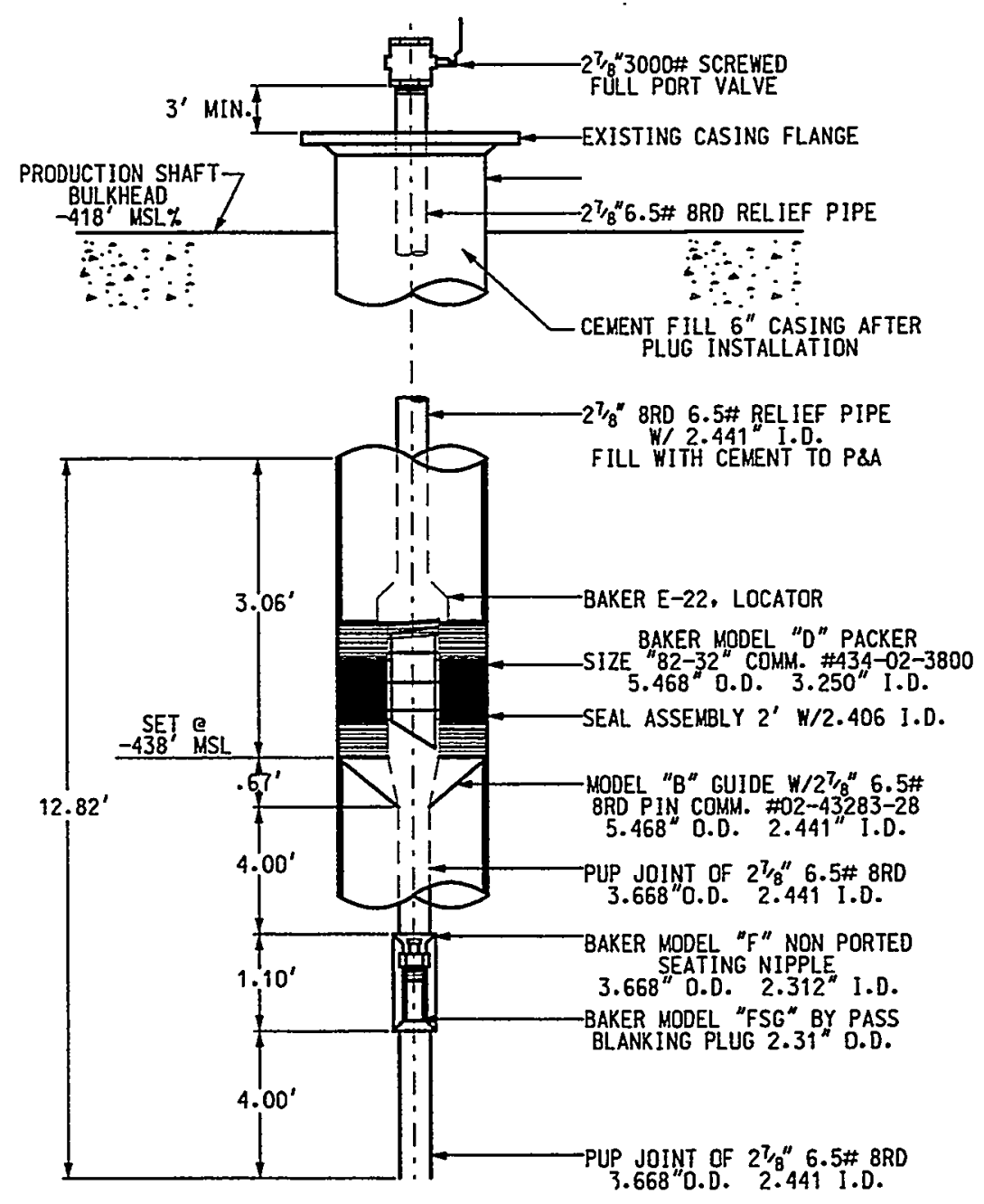

Figure 7.2 Production Shaft Relief Bridge Plug 
the relief pipe within the bridge plugs consisted of a $27 / 8$-inch bridge plug, cement plug and weld cap.

General P\&A of bulkhead casings included demolition and removal (D\&R) of all auxiliary piping, valves, fittings and instrumentation installed in and around the casings and bulkhead area. In addition, at the raisebores, the Halon-confinement metal enclosure around the bulkheads was removed to gain clearer access to the casings. The casings were then cleaned to remove hydrocarbons and rust and scale with a high pressure, rotating head, solvent wash. The bridge plugs were then set to the specified elevation. Two types of bridge plugs were used to P\&A the casings. The under-12-inch diameter casings received a Baker type $\mathrm{N}-1$, wireline mechanically set Cast Iron Bridge Plug (CIBP). The 12-inch and larger diameter casings received a Baker type 300-73 Permanent Inflatable Bridge Plug (PIBP). The bridge plugs as installed were specified to have the capability to withstand a minimum differential pressure of 750 psi without movement.

A cement grout plug was then installed above the bridge plugs, through an injection tube placed slightly above the bridge plug. The cement mix used was specified to have a minimum compressive strength of $3,000 \mathrm{psi}$ in 28 days. The mix was specified as a non-shrink cement, at least $0.1 \%$ expansive as measured at 7 days. The cement plug was placed from the bridge plug to the casing flange. After the cement cured, the casing flange was cut off and a weld cap installed on the casing. A visual and non-destructive examination (NDE) of each weld was conducted. The completed P\&A of the casings provided three levels of confinement of storage chamber fluids to the mine: bridge plug, cement plug, and weld cap.

\subsection{Production and Service Shafts}

The 18-ft diameter Production Shaft and 9-ft diameter Service Shaft were plugged and abandoned by installing a reinforced concrete plug at the surface; the plug was keyed into the shaft collar. The layout and dimensions of the headframe buildings that house the shafts had an impact upon the shape and dimensions of the plugs. At the Production Shaft headframe building, ample space was available to support the installation of a 22 -ft diameter by 3-ft thick octagonshaped plug. The limited space and configuration of existing equipment foundations in the Service Shaft headframe building resulted in a trapezoidal-shaped plug approximately $15 \mathrm{ft}-9$ inch wide by $13 \mathrm{ft}-6$ inch long and 2-ft thick.

To gain access to the Production Shaft for the installation of the plug formwork, the protective fencing around the shaft was demolished and removed. All electrical, instrumentation and security cables, wires and conduits, as well as the Morton 16-inch brine-fill line (for the Markel Mine) were demolished and removed. The man cage and materials cage were lowered into the mine and the wire cables cut. Cage guides were removed and the remaining wire cable wound onto the hoist drum for D\&R with that system.

Formwork within the shaft for the plug included W8x10 steel beams on 32-inch centers, installed across the existing timber supports, with $\mathrm{C} 4 \times 5.4$ steel channel bracing. The formwork was topped with a tongue and grove wood deck over the shaft to support the concrete. A series of 44 equally spaced, $21 / 4$-inch diameter by 20 -inch deep holes were drilled around the perimeter of the shaft collar for reinforcement tie dowels. A \#8 rebar was epoxy grouted into these holes and tied to the plug reinforcement steel, to key the plug into the shaft collar. The shaft plug reinforcement was \#8 rebar at 6 inch on center, both ways and 2-\#8 bent rebar, 18 inches apart, around the perimeter of the plug. 
Additional decommissioning work at the Production Shaft site included the D\&R of the mine air conditioning system compressors, blowers, auxiliary piping, electrical, instrumentation and duct work to the headframe building. The hoist house, Building Number 521, was demolished down to the slab. The hoist pits in the building were backfilled with structural fill and a 4inch thick concrete cap slab installed. Concrete curbs and foundations were removed and the surface smoothed to produce an approximate $81 \mathrm{ft}$ by $46 \mathrm{ft}$ uniform surface slab. A new lighting panel was installed and transformer WITR-27 relocated to the former condenser slab. Lighting was provided for the Production Shaft site area.

The D\&R work necessary to gain access to the Service Shaft collar consisted of removal of the false floor grating and support structure. $D \& R$ were conducted on the 2-inch through 24-inch diameter piping systems that penetrated the shaft. D\&R was conducted on the hydraulic unit, air compressor, service lines, electrical and instrumentation cables and conduit. The man cage and service cage were lowered into the mine and the wire cables cut. Remaining wire cable was wound onto the hoist drums for D\&R with those systems.

The Service Shaft headframe building is $24 \mathrm{ft}$ by $25 \mathrm{ft}$ in plan and includes a massive foundation for the man cage hoist and hydraulic unit. This $10 \mathrm{ft}$ by $8 \mathrm{ft}$ foundation was constructed approximately $5 \mathrm{ft}$ above the finished floor and shaft collar elevation. Thus, a false floor, consisting of steel grating and support structure, was constructed to approximately the elevation of the massive man cage hoist foundation. With the false flooring removed, a trapezoidal-shaped shaft plug was selected, considering the minimal clearance between the shaft collar and this massive foundation. The formwork within the shaft consisted of vertical $2 \times 12$ 's on 16 -inch centers spanning the shaft collar, with tongue and grove wood deck over the shaft to support the concrete. The shaft plug reinforcement was tied to \#5 dowels, epoxy grouted into the building floor and hoist foundation at 12 inch on center. The completed plug is at elevation $59.35 \mathrm{ft} \mathrm{MSL}$ approximately $1 \mathrm{ft}-10$ inch above the finished floor $57.5 \mathrm{ft}$ MSL elevation of the headframe building.

Additional decommissioning activities at the Service Shaft area included concrete fill of the vehicle barrier for oil piping into the Service Shaft. All motor control centers (MCC) and control panels in the motor control center, Building Number 564, serving decommissioned systems at the Service Shaft were removed. The Halon systems were demolished and removed in the hoist house and motor control center. The hoist house, Building Number 551, was demolished to the foundation and hoist equipment was removed.

The Production and Service Shaft headframe buildings were securely locked to prevent unauthorized access. Perimeter fencing remains at each site and the gates were securely locked.

\subsection{Wells Plugging and Abandonment}

A substantial amount of abandonment activity was also accomplished from the surface. This work [Walk, Haydel and Associates, 1998] included the P\&A of the Vent Hole and West Fill Hole casings, monitoring wells and exploratory boreholes, and conversion of the East Fill Hole to a monitoring configuration (refer to Section 8.1). The Vent Hole and West Fill Hole were plugged and abandoned in a manner similar to the underground bulkhead casings (Section 7.1), with bridge plug, cement plug, and casing cap. The boreholes and monitoring wells were plugged and abandoned with a cement plug and casing cap. Table 7-2 summarizes the relevant data for the plugged and abandoned wells. 
The Vent Hole 13 3/8-inch O.D. casing was plugged with a wireline-set cast iron bridge plug, CIBP, placed at elevation $-360 \mathrm{ft}$ MSL. This was followed by an initial 70 -ft thick cement plug, which was allowed to cure for 24 hours. A second, approximately 395 -ft thick cement plug

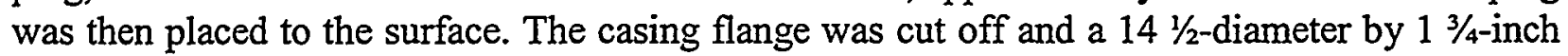
thick steel plate welded to the casing. A 4-inch square brass monument marker was mounted to the steel plate, to be used as a survey point for future site subsidence monitoring.

Table 7-2 Summary of Well Plugging and Abandonment Data

\begin{tabular}{|c|c|c|c|c|}
\hline Location & Casing Size & $\begin{array}{c}\text { Depth Of } \\
\text { Casing }\end{array}$ & $\begin{array}{c}\text { Bridge Plug } \\
\text { Setting Depth }\end{array}$ & $\begin{array}{c}\text { Cement Plug } \\
\text { Thickness }\end{array}$ \\
\hline Vent Hole & $133 / 8$ inch & $-376 \mathrm{ft} \mathrm{MSL}$ & $-360 \mathrm{ft}$ MSL & $460 \mathrm{ft}+/-$ \\
\hline West Fill Hole & 30 inch & $-623 \mathrm{ft} \mathrm{MSL}$ & $-400 \mathrm{ft}$ MSL & $450 \mathrm{ft}+/-$ \\
\hline $\begin{array}{l}\text { EH-1 Total Depth } \\
379.5 \mathrm{ft} \text { RKB }\end{array}$ & $\begin{array}{l}85 / 8 \text { inch Surf. } \\
4 \text { inch Cemented } \\
1 \text { inch Hanging }\end{array}$ & $\begin{array}{c}166.5 \mathrm{ft} \mathrm{RKB} \\
280.5 \mathrm{ft} \mathrm{RKB} \\
355 \mathrm{ft} \mathrm{RKB}\end{array}$ & N/A & $371.5 \mathrm{ft}+/-$ \\
\hline $\begin{array}{l}\text { EH-2 Total Depth } \\
400 \mathrm{ft} \text { RKB }\end{array}$ & $\begin{array}{l}85 / 8 \text { inch Surf. } \\
4 \text { inch cemented }\end{array}$ & $\begin{array}{l}201 \mathrm{ft} \mathrm{RKB} \\
299 \mathrm{ft} \mathrm{RKB} \\
\text { Open to TD }\end{array}$ & N/A & $360 \mathrm{ft}+/-$ \\
\hline $\begin{array}{l}\text { EH-3 Total Depth } \\
406 \mathrm{ft} \text { RKB }\end{array}$ & $\begin{array}{l}85 / 8 \text { inch Surf. } \\
4 \text { inch Cemented } \\
1 \text { inch Hanging }\end{array}$ & $\begin{array}{l}216 \mathrm{ft} \mathrm{RKB} \\
300 \mathrm{ft} \mathrm{RKB} \\
384 \mathrm{ft} \mathrm{RKB}\end{array}$ & N/A & $398 \mathrm{ft}+1-$ \\
\hline $\begin{array}{l}\text { BH-3 Total Depth } \\
250 \mathrm{ft} \text { RKB }\end{array}$ & $\begin{array}{l}14 \text { inch Surf. } \\
103 / 4 \text { inch Cem. } \\
6 \text { inch Hanging }\end{array}$ & $\begin{array}{l}34 \mathrm{ft} \mathrm{RKB} \\
187 \mathrm{ft} \mathrm{RKB} \\
167 \mathrm{ft} \mathrm{RKB}\end{array}$ & N/A & $242 \mathrm{ft}+/-$ \\
\hline $\begin{array}{l}\text { BH-4 Total Depth } \\
250 \mathrm{ft} \text { RKB }\end{array}$ & $\begin{array}{l}14 \text { inch Surf. } \\
85 / 8 \text { inch Cem. } \\
6 \text { inch Hanging }\end{array}$ & $\begin{array}{c}44 \mathrm{ft} \mathrm{RKB} \\
250 \mathrm{ft} \mathrm{RKB} \\
175.5 \mathrm{RKB}\end{array}$ & N/A & $242 \mathrm{ft}+/-$ \\
\hline $\begin{array}{l}\text { BH-5 Total Depth } \\
250 \mathrm{ft} \text { RKB }\end{array}$ & $\begin{array}{c}14 \text { inch Surf. } \\
65 / 8 \text { inch Cem. } \\
4 \text { inch Hanging }\end{array}$ & $\begin{array}{c}34 \mathrm{ft} \mathrm{RKB} \\
250 \mathrm{ft} \mathrm{RKB} \\
168 \mathrm{RKB}\end{array}$ & N/A & $242 \mathrm{ft}+1-$ \\
\hline $\begin{array}{l}\text { BH-6 Total Depth } \\
250 \mathrm{ft} \text { RKB }\end{array}$ & $\begin{array}{c}14 \text { inch Surf. } \\
103 / 4 \text { inch Cem. } \\
6 \text { inch Hanging }\end{array}$ & $\begin{array}{c}34 \mathrm{ft} \mathrm{RKB} \\
189 \mathrm{ft} \mathrm{RKB} \\
164 \mathrm{ft} \mathrm{RKB} \\
\end{array}$ & N/A & $242 \mathrm{ft}+1-$ \\
\hline $\begin{array}{l}\text { BH-7A Total } \\
\text { Depth } 288 \mathrm{ft} \mathrm{RKB}\end{array}$ & $51 / 2$ inch & $\begin{array}{l}192 \mathrm{ft} \mathrm{RKB} \\
\text { Open to TD }\end{array}$ & N/A & $280 \mathrm{ft}+/-$ \\
\hline $\begin{array}{l}\text { BH-9 Total Depth } \\
192 \mathrm{ft} \text { RKB }\end{array}$ & $41 / 2$ inch & $\begin{array}{l}175 \mathrm{ft} \mathrm{RKB} \\
\text { Open to TD }\end{array}$ & N/A & $184 \mathrm{ft}+/-$ \\
\hline $\begin{array}{l}\text { M-1 Total Depth } \\
190 \mathrm{ft} \text { RKB }\end{array}$ & $\begin{array}{l}103 / 4 \text { inch Surf. } \\
6 \text { inch Hanging }\end{array}$ & $\begin{array}{c}60 \mathrm{ft} R K B \\
190 \mathrm{ft} \mathrm{RKB}\end{array}$ & N/A & $182 \mathrm{ft}+/-$ \\
\hline $\begin{array}{l}\text { M-2 Total Depth } \\
183 \mathrm{ft} R K B\end{array}$ & $\begin{array}{l}65 / 8 \text { inch Surf. } \\
4 \text { inch Hanging }\end{array}$ & $\begin{array}{c}70 \mathrm{ft} \mathrm{RKB} \\
174 \mathrm{ft} \mathrm{RKB}\end{array}$ & N/A & $175 \mathrm{ft}+/-$ \\
\hline $\begin{array}{l}\text { M-4 Total Depth } \\
181 \mathrm{ft} \text { RKB }\end{array}$ & $\begin{array}{l}65 / 8 \text { inch Surf. } \\
4 \text { inch Hanging }\end{array}$ & $\begin{array}{c}63 \mathrm{ftRKB} \\
172 \mathrm{ft} \mathrm{RKB}\end{array}$ & N/A & $173 \mathrm{ft}+/-$ \\
\hline
\end{tabular}

(TD = total depth, $\mathrm{MSL}=$ mean sea level, $\mathrm{RKB}=$ reference Kelly bushing) 
The West Fill Hole 30-inch O.D. casing was plugged with a permanent inflatable bridge plug, PIBP, set at elevation $-400 \mathrm{ft}$ MSL. This was followed by an initial $100-\mathrm{ft}$ thick cement plug, which was allowed to cure for 24 hours. A second, approximately $360-\mathrm{ft}$ thick cement plug was then placed to the surface. The casing flange was cut off and a 32 inch-diameter by $1 \frac{3 / 4}{4}$ inch thick steel plate welded to the casing. A 4-inch square brass monument marker was mounted to the steel plate, to be used as a survey point for subsidence monitoring of the decommissioned site.

Exploratory holes EH-1, EH-2 and EH-3 were completed into the top of the salt dome. The completions consisted of an 8 5/8-inch surface casing and 4-inch cemented casing. EH-1 and EH3 also included a 1 inch PVC hanging casing. P\&A of the exploratory holes consisted of spotting salt saturated cement from total depth (TD) to the top of salt elevation. After curing, this was followed by bentonite cement grout placed to the surface. The casings were cut off $3 \mathrm{ft}$ below grade and a $1 / 4$-inch thick steel plate welded to the surface casing. The well surface area was backfilled and restored.

Boreholes BH-3 through BH-7A and BH-9 were also completed into the top of salt. Boreholes $\mathrm{BH}-3$ through $\mathrm{BH}-6$ were vertically drilled. Boreholes $\mathrm{BH}-7 \mathrm{~A}$ and $\mathrm{BH}-9$ were directionally drilled and completed as monitoring wells without a hanging casing. The vertical boreholes included a 6-ft or 4-inch perforated hanging casing. Sand and gravel were placed in the annulus of the cemented casing at the perforated intervals of the hanging casing. A bentonite plug and cement fill to the surface was placed in the cemented casing annulus, above the upper perforated interval of the hanging casing. P\&A of the boreholes consisted of spotting salt-saturated cement from TD to the top of salt elevation. After curing, this was followed by bentonite cement grout placed to the surface. The casings were cut off $3 \mathrm{ft}$ below grade and a $1 / 4$-inch thick steel plate welded to the surface casing. The well surface area was backfilled and restored.

Monitoring Wells M-1, M-2 and M-3 were also completed into the top of salt. The wells consist of a surface casing and perforated hanging casing to TD in an open hole with sand and gravel pack. P\&A of these wells consisted of spotting salt-saturated cement from TD to the top of salt elevation. After curing, this was followed by bentonite cement grout placed to the surface. The casings were cut off $3 \mathrm{ft}$ below grade and a $1 / 4$-inch thick steel plate welded to the surface casing. The well surface area was backfilled and restored.

Monitoring Wells M-5, M-6, M-7 and M-8 were completed similarly to the above monitoring wells. These four wells are being left open and operational for at least the five-year postclosure monitoring period, as mandated by the state of Louisiana. These wells will be P\&A as described above when they are no longer needed. The relative location of the monitoring wells (M), as well as the exploration boreholes (BH), in relationship to Sinkhole \#1, are shown in Figure 7.3. The coordinates shown (in units of $\mathrm{ft}$ ) are based on the Louisiana State Plane Coordinate System, South Zone. The relative location of the exploratory holes $(\mathrm{EH})$ with respect to Sinkhole \#1 was shown previously in Figure 4.2.

\subsection{Pumps}

There were 11 crude oil booster pumps during the SPR operational phase. These were electric, submersible pumps suspended from the manifold room, through the Service Shaft bulkhead, into the bottom of the lower crude oil storage chamber. Eight of these pumps were pulled and sold as excess property. Three were used for the first phase of oil skimming. Following oil 


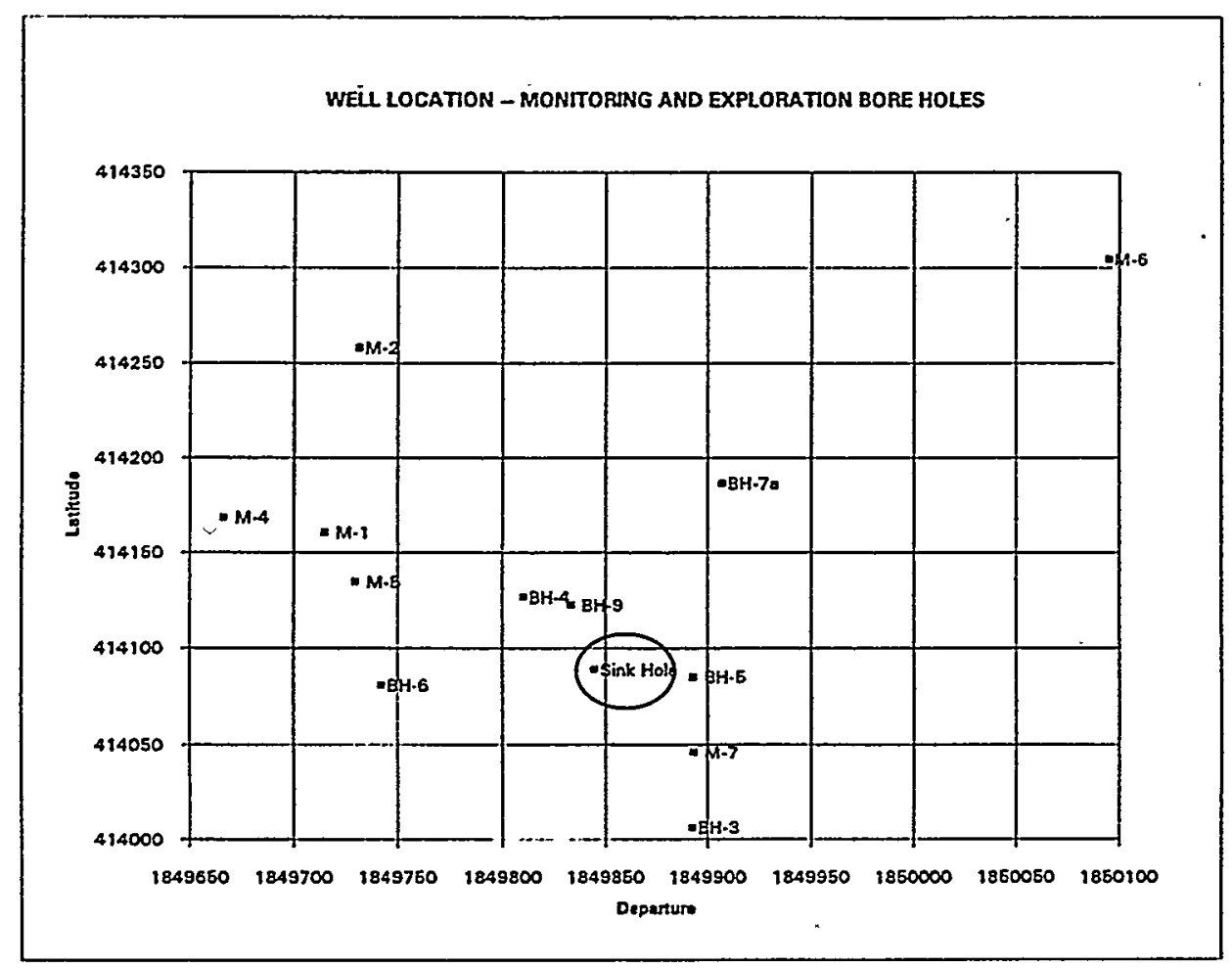

Figure 7.3 Relative Locations of Monitoring and Exploration Bore Holes

skimming, the decision was then made for economic reasons to drop and abandon the remaining three pumps (in casings 4, 7, and 9) into the mine [Eldredge, 1999]. The two skim pumps (in casings 3 and 11) were also dropped and abandoned following the remaining phases of oil skimming. The downhole pumps were abandoned in-place per verbal approval received from the Louisiana Department of Natural Resources, LDNR, on January 28, 1999. A letter from DOE to the LDNR dated February 24, 1999 confirmed and documented this verbal concurrence. It should be noted that casings used or planned for skimming were cut and also dropped into the brine-filled oil storage chamber prior to Phase II and Phase III skimming.

\subsection{Abandonment of Surface Facilities}

The demolition and removal (D\&R) of all process, mechanical, electrical and instrumentation systems and equipment associated with the oil storage operations were a major segment of the overall decommissioning effort.

The underground fire-water piping system was drained to the extent possible and left in place for possible future needs. All oil process, drain, brine and fuel gas pipe, valves and fittings have been completely or partially D\&R'd. The entire above-grade oil movement, process, fuel, foam and deluge pipe, valves, and fittings have been removed from the site. The below-grade piping has been drained, purged, cut to a minimum of $3 \mathrm{ft}$ below grade, capped, and abandoned in-place. Buried valves on abandoned piping have been closed and the valve operators cut off below grade at the valve body or a minimum of $3 \mathrm{ft}$ below grade. Piping which penetrated 
building floors or walls was cut flush or removed, and welded plates or building sheet metal were installed. Crude oil piping outside the fence, between the main site and the fill area, was isolated, flushed with inhibited water, and drained or vacuumed. Piping from the main site to the Service Shaft was flushed with fresh water, isolated, and drained. Cathodic protection was not provided since the site has all incoming power de-energized. Inert gas generators and the flare stack were removed and salvaged.

Equipment foundations have been completely D\&R'd or partially D\&R'd and abandoned in place. Massive foundations such as the mainline pump foundations in Building 516 were abandoned in place. Pile-supported piping foundations have been $D \& R$ 'd to a minimum of $2 \mathrm{ft}$ below grade, or to the top of the pile cap, and abandoned in place. The meter/prover foundations were D\&R'd to just below the height of the area spill containment curb. The spill containment curb for the meter/prover was then filled with compacted structural fill and a 4-inch thick concrete cap installed to produce a single slab, approximately 18 inch above grade and sloped to drain.

Decommissioning of electrical power and controls, generators, switch gear that were not mine-related, plus associated instrumentation, control and security systems consisted of D\&R, salvaging, or abandonment in place. The main site transformers and associated electrical equipment needed to provide power to the buildings were left in place. All above-grade transformers, motor control centers (MCC's), panels, cables, wires and conduits were D\&R'd to a minimum of 12 inch below grade. Security cameras were D\&R'd, wire fence and door sensors were D\&R'd or disconnected. Conduits were plugged with fiberglass and capped with mastic compound. Cables and wires in the control room and MCC rooms that serve removed or disconnected MCC's and control panels were rolled and abandoned in place. Circuits for lighting and buildings were preserved and transferred to GSA.

Hoisting equipment was removed or salvaged. Service Shaft fencing around the headframe remains intact. Fencing around the hoist building was demolished, along with the hoist building. The oily water treatment system was flushed with fresh water until all oil was vacuumed and removed; it was then filled with cement and the risers cut 3 feet below grade. Metal plates were welded to cap the risers. The Station Sump was decommissioned in the same manner. Water wells \#1 and \#3 were plugged and abandoned.

The infrastructure that was preserved for possible alternate (non-DOE, non-SPR) site use includes roads, parking areas, drainage systems, buildings and utility systems for water, sanitary sewer, fire protection water and electrical power to buildings, equipment and site lighting. The buildings were assigned to General Services Administration (GSA) for sales or other disposition, with inventories, pumps, pipes, motor controls transferred to another site or salvaged; the DOE currently retains the ownership and custody responsibilities. Headframes and air-handling equipment, with the exception of the mine air drier, remain intact and were assigned to GSA for final disposition. Mineral rights were also assigned to the GSA. 


\section{ENVIRONMENTAL MONITORING}

Periodic, near-term monitoring of surface conditions at the Weeks Island site was described in Section 4.1 for perimeter inspections, and Section 4.3.2 for surface subsidence (leveling) surveys; both types of monitoring are anticipated to continue through the end of 2004. Similar nearterm environmental monitoring efforts for brine outflow volume from the East Fill Hole, and potential hydrocarbon (oil) contamination of brine released from the mine (into six monitoring wells) are discussed in the following sections.

\subsection{East Fill Hole Brine Outflow Measurements}

Upon completion of brine fill (described in section 5.3), all manmade mine openings were plugged, sealed, and abandoned (Sections 7.1, 7.2, 7.3), with the exception of the East Fill Hole $(\mathrm{EFH})$. The EFH has been renovated to accommodate brine pressure-relief due to long-term creep closure of the mine. A brine flow measuring system has been installed in the EFH to monitor equilibration and long-term environmental stabilization of the mine [Levin, 1999]. Monitoring will continue for approximately five years, beginning in late 1999 and continuing through the end of 2004. Upon conclusion of this activity, the flow measuring equipment and support systems will be removed and the EFH will be plugged: The purpose of the brine monitoring system is to measure the flow of brine out of the mine and into the overlying aquifer. The collected data on brine outflow will be used to estimate the period for brine thermal stabilization and long-term mine creep rate. The monitoring is required by the State of Louisiana, Department of Natural Resources, Office of Conservation, for environmental reasons [Gibson, 1999]. The brine monitoring will also be used to provide information about the mine stability and to help validate the mine closure rate. The EFH will be plugged and surface support systems will be removed after monitoring is completed.

The brine flow monitoring system and station was installed as an integral part of the EFH; it is illustrated in schematic form in Figure 8.1. The EFH was perforated through to the outside formation sediments just above the top of salt. The quality, pressure, and flow rates of the brine discharge will be monitored and, to some extent, be controlled by restricting flow through the discharge pipe. The large perforated casings provide negligible flow resistance, and discharge will be limited by the permeability of the overburden. A flowmeter device was installed through an inflatable plug such that all of the fluids escaping the mine must pass through a 2-inch diameter tube equipped for electronic flow measurement. The flow monitoring system consists of two sub-systems, the packer/tube/hanger (PTH) system and the non-potable water (NPW) system. The PTH system is used to house the brine flow sensor, confine flow through the sensor, and permit brine to pass to the aquifer. The NPW system is used to prevent salt from precipitating in the flow path from the packer to the aquifer. The conceptual design and operating procedures for the brine flow monitoring system were described by Levin [Levin, 1999]; Walk, Haydel and Associates and PB-KBB provided the final design and construction drawings, and Grady Crawford provided field installation of the brine flow monitoring system.

The brine flow-monitoring configuration has an inflated packer that seals the casing. A packer was lowered down the EFH by sections of tubing. The packer was inflated to provide a casing seal below the top-of-salt level. A crossover and fiber-lined tubing section is located below the top-of-salt and connects to the top of the packer. A perforated tubing section, and 2 7/8inch O.D. J-55 8-RD EUE tubing connects to the lined tubing section and runs to the surface 
where it is supported by a hanger/lubricator assembly. The tubing and casing perforations are located at the bottom of the aquifer. The brine flow is measured by an electromagnetic borehole flowmeter (EBF) sensor probe that was lowered and centered in a lined tube section just above the packer and below the perforated tubing. Brine under pressure will flow through the packer center tube, flow monitoring section, perforated tubing and casing, and into the aquifer. A nonpotable water tank system adjacent to the EFH provides metered water that is injected inside and near the bottom of the packer tube to prevent possible salt precipitation within the brine flow path. The EBF sensor probe transmits electrical signals through a supporting cable to a surface electronics module. The module converts the signal to a flow rate. Initial brine flow will result, in part, from both thermal stabilization and mine creep. Brine flow is expected to taper to a diminished rate as the brine reaches thermal equilibration, at which point the flow will be due to mine creep. Further details on the overall brine flow monitoring system, its development, emplacement, operation, and maintenance are found elsewhere [Levin, 1999; Walk, Haydel, 1999].

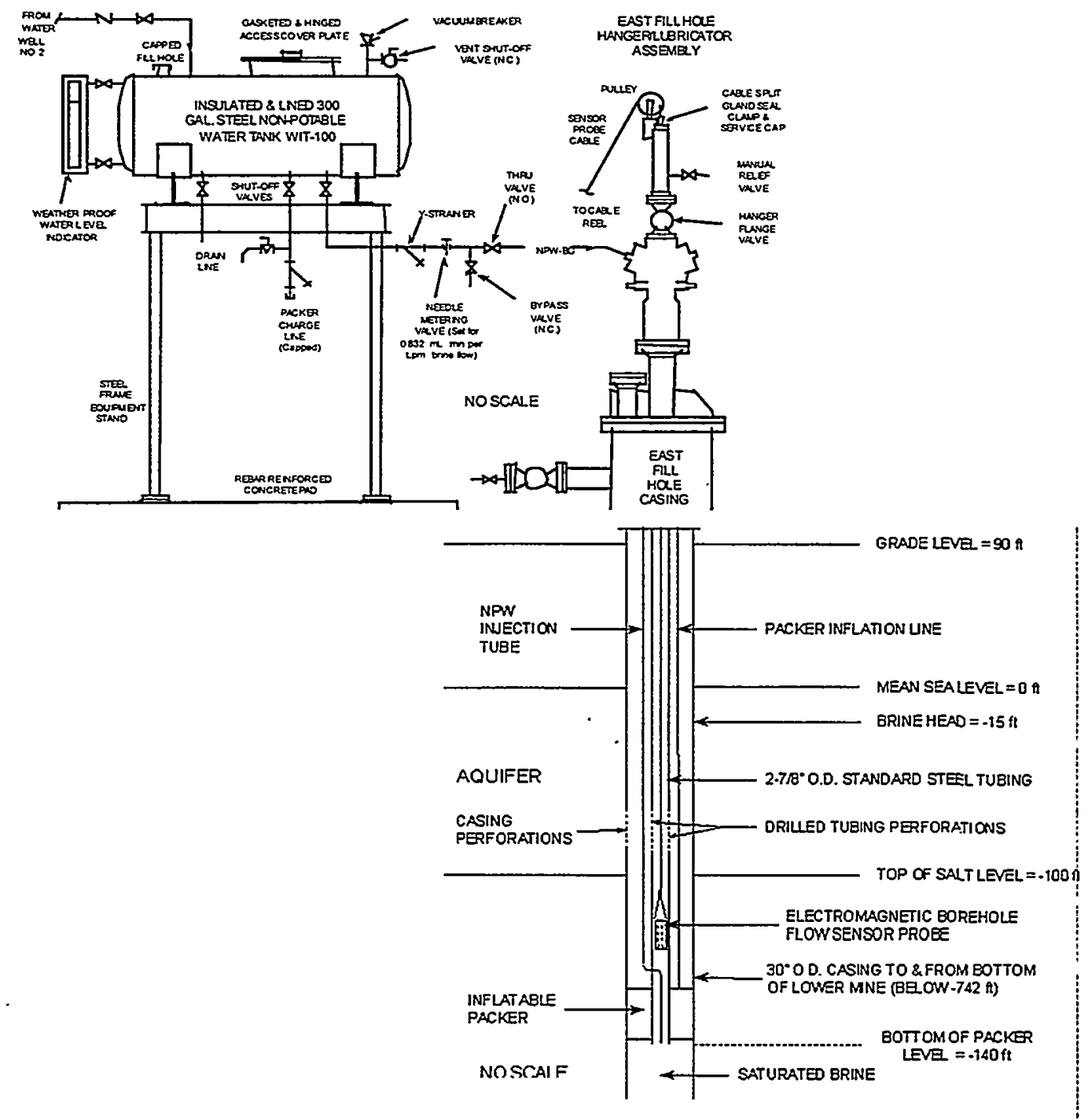

Figure 8.1 East Fill Hole Brine Flow Measuring Station Schematic 
The known volume of the mine at abandonment was approximately 72 to 73 million bbl. For the purposes of estimating credible maximum, anticipated brine flow rates and sizing the instruments, the mine subsidence due to creep closure was estimated to be 0.01 to $0.05 \mathrm{ft} /$ year. The rates are higher than those predicted by previous modeling (described in Section 8.2) to account for the higher than predicted subsidence rates that have been measured at the site. This subsidence rate (range) is similar to rates observed in 1983-1990 when the mine was full of oil; refer also to Sections 4.3.2 on recent subsidence measurements and Section 4.3.3 for predicted subsidence rates. This subsidence rate range translates to a volume change rate of 8,400 to 43,000 $\mathrm{bbl} / \mathrm{year}$, or an instantaneous brine flow rate of 0.67 to $3.5 \mathrm{gpm}$ ( 2.5 to $13 \mathrm{Lpm})$. Thermal equilibration of the brine with the surrounding salt will account for additional brine flow that will decay to zero. Therefore, the total brine flow rate is estimated to be between 0.8 to $4.5 \mathrm{gpm}$ ( 3 to 17 Lpm); refer to Section 8.2, following, for calculated brine outflow predictions.

\subsection{Brine Outflow Predictions}

Storage volume loss of the Weeks Island mine after decommissioning, due predominantly to long-term salt creep closure, is of long-term interest since the brine discharged from the mine must be safely discarded. Mine pressurization would theoretically be beneficial in reducing mine deformations and hence any detrimental consequences associated with subsidence, stresses, and strains [Hoffman and Ehgartner, 1994]. A sealed mine would eliminate any environmental contamination from either residual oil that was not recovered during mine closure or from elevated salinity levels in the groundwater above the dome. In reality, the salt above the mine may be fractured and damaged and contains at least one sizable, potential leak path, Sinkhole \# 1.

To prevent or minimize brine discharge through the sinkhole(s), the East Fill Hole is being used to preferentially flow fluid out from the bottom of the mine and discharge it into the saline portions of the groundwater directly above the top of salt. Since oil floats atop brine and the East Fill Hole connects to the bottom of the lower mine level, only brine will be discharged through the East Fill Hole. By keeping mine pressure at or near hydrostatic pressure, this controlled discharge should effectively minimize residual oil from seeping out though any fracture and dissolution channels in the salt above the mine. It also provides a means of monitoring the quantity and quality of fluid leaving the mine, as described in Section 8.1.

To estimate the quantity of brine that the mine will discharge through the preferential East Fill Hole pathway over time, and to predict the future state of the site, a 3-D finite element analysis was previously performed [Hoffman and Ehgartner, 1994]. This analysis assumed hydrostatic brine pressure in the mine. The results predicted that after closure, the mine will continue to close, but at a rate of less than $5 \%$ of the rate when the mine was oil filled. At this rate, brine was predicted to be discharged into the overburden at approximately $12 \mathrm{gph}(2,500 \mathrm{bbl} / \mathrm{year})$. The predicted subsidence rate after decommissioning is less than $3 \%$ of the rate when the mine was oil filled (approximately $0.2 \mathrm{ft} /$ year). This prediction is slightly lower then the estimate presented above (Section 8.1), assuming that in the long-term, moisture-induced creep will be negligible (refer to Section 4.3.3). The subsidence rate predicted after decommissioning was only 0.002 $\mathrm{ft} /$ year (0.06 in/year), slightly less than the estimated domal uplift of $0.008 \mathrm{ft} /$ year [Acres, 1987]. Mine stability is improved after decommissioning because of the increased pillar confining pressures. Hence, the analysis results [Hoffman and Ehgartner, 1994] showed improved long-term conditions resulting from brine filling the mine after oil removal. 


\subsection{Groundwater Monitoring for Hydrocarbons}

Groundwater monitoring conducted over the last several years at Weeks Island has indicated no petroleum hydrocarbon contamination. The scope of this monitoring program (to be described) has been expanded, as part of the mine decommissioning process, for environmental monitoring purposes. The number of wells monitored will be increased from four to six and monitoring will be conducted quarterly, through 2004 [Gibson, 1999]. Monitoring serves to evaluate the potential for release/containment of any unskimmed and nonrecovered crude oil that remains trapped in the decommissioned mine.

A background or ambient total petroleum hydrocarbon (TPH) condition was established before mine brine backfill was completed; four monitoring wells (M5, M6, M7, and M8) were screened across the water table and around the sand-filled Sinkhole \#1. This ambient TPH level has been determined by 10 sampling episodes over more than a 3-year period, with triannual sampling; the last "baseline" sampling was conducted in June 1999. The "detection" monitoring mode commenced with samplings on November 9,1999 . The previous 4 well monitoring array is being supplemented with a new sampled position of fluids leaving the East Fill Hole (from the perforated zone), and with samples from a fully screened well located near the center of Sinkhole \#1, well no. 4270 (refer to Figure 4.2). Well 4270 was initially installed to "prove" the freezing conditions of the frozen plug constructed within the original sinkhole. This well cannot be sampled until the former freezewall retreats and water samples from the sandy backfill can be obtained. The new sampling schedule for "detection" TPH monitoring is to be quarterly.

Monitoring field measurements include depth to water (reduced to elevations) and contoured for direction and gradient around the sinkhole. Depth to water will also be measured from the East Fill Hole. Discrete samples of static ground water will be obtained from each well and sampling point. A contract laboratory will perform analyses on the groundwater samples for the single parameter "Total Petroleum Hydrocarbons," TPH. The methodology for completing these analyses is an Environmental Protection Agency Method 1664 (IR) screening test. A SPR procedure, "Revised Routine Sampling For The Purpose Of Detection Monitoring Weeks Island Long-Term (WILT) Ground Water Monitoring Wells, Rev. 2.," provides details for routinely conducting these quarterly environmental monitoring samplings. A parallel "WILT Data Handling and Management Plan, Rev. 2," prescribes data handling and reporting procedures. Data for these samples will be summarized and reported to the Louisiana Department of Natural Resources, Office of Conservation, on a quarterly basis. This is proposed to continue for a minimum of five years and then will be reviewed. 


\section{RISK ASSESSMENT RESULTS RELEVANT TO POST-CLOSURE}

A risk assessment study with conclusions relevant to the long-term, post-closure phase of the Weeks Island SPR facility was conducted in late 1998. This study [Molecke et al., 1998] specifically evaluated the potential risks of environmental impact (within the meaning of the $\mathrm{Na}$ tional Environmental Policy Act, NEPA) of abandoning large volumes of nonrecovered crude oil as part of site decommissioning and abandonment, and up to 100 years thereafter. For purposes of this evaluation, and credible DOE SPR responsibility, 100 years was defined as the "longterm." This section serves to summarize and reiterate the pertinent findings of these assessments.

The 1998 risk assessment study [Molecke et al., 1998] semi-quantitatively evaluated multiple, long-term environmental contamination risk scenarios that could result from the potential leakage of detectable levels ( $\leq 100 \mathrm{bbl} /$ year) up to a total of 1.5 million barrels of residual crude oil entombed in the Weeks Island SPR mine. This assessment provided continuity with, and extension of, earlier risk evaluations conducted and documented by the DOE in the Environmental Assessment for Decommissioning the Strategic Petroleum Reserve Weeks Island Facility (EA), [DOE, 1995b]. The 1995. evaluations considered the potential impacts of abandoning only 10,000 to $30,000 \mathrm{bbl}$ of crude oil. The fact that 1.47 million bbl of crude oil were actually abandoned in the Weeks Island mine at the conclusion of drawdown and oil skimming operations (refer to Section 5.3) lends relevancy and further credibility to the risk assessment conclusions.

In order to help the selected risk assessment panel members in their evaluations, they were presented with relevant information on:

- $\quad$ possible mechanisms for long-term oil entrapment, i.e., entrapment in crushed or rubblized salt remaining in the mine, in roof pockets (salt roughness) in both the upper and lowerlevel mine, or in sediments within the leakage features (sinkholes) or above the salt dome;

- potential mechanisms for residual oil escape from the mine, e.g., escape through either natural pathways in the salt (sink holes, salt fractures, salt dilatancy, etc.) or through compromised, man-made pathways (sealed shafts, fill holes, brine pressure-relief pathways, monitoring wells, etc.); and,

- relevant details on decommissioning operations and concerns, including site and facility subsidence and mine instabilities.

Panel members were then asked to individually evaluate (in terms of specific value ranges) the likelihood (probability) and consequence (severity) of each of the defined, potential risk events, to the best of their knowledge. Overall risks were then calculated, using a Delphi methodology [Linstone and Turoff, 1975], and interpreted. With this methodology, the calculated risk equals the product of the likelihood times the consequence for each risk event. Potential longterm consequences and risks were stated in terms. of dollars, i.e., expenses specifically for oil contamination cleanup and facility remediation costs only.

The long-term, oil leakage risk contamination scenarios are, of course, dependent on the total quantity of oil that potentially could escape from entrapment in the Weeks Island SPR mine, in either a one-time or an intermittent manner. A significant, observable oil-leakage rate and volume would presumably initiate Department of Energy SPR Project (or successor governmental agency) decisions and remediation actions when and if any detectable oil leakage occurs, in order to minimize further oil release or environmental contamination. 
For all of the evaluated risk events, the calculated average, perceived likelihood of occurrence decreased significantly as the oil-leakage volume levels increased. Conversely, the average perceived consequence of the event increased as the potential volume of oil leakage increased. In general, the risk events with the calculated highest average risks (expense values) were associated with the highest likelihood values -- but with the smallest consequence values. For example, the panel members judged the long-term likelihood of a leak level of "detectable and up to 100 bbl/year of oil" as "likely" (probability range of 0.1 to 1.0). While a couple of the resultant, calculated potential oil clean-up and remediation risk expenses were appreciable (in the vicinity of $\sim \$ 100,000$, with moderately large calculated uncertainties), they were ALL significantly smaller in magnitude than nominal operational costs spent for facility decommissioning.

Based on the defined and calculated environmental risks presented in this risk assessment study [Molecke et al., 1998], none of the evaluated long-term, oil-leakage risk events appeared to satisfy the definition of "significant environmental impact" in National Environmental Policy Act, NEPA [DOE, 1995b] terminology. Post-closure environmental impacts and future expenses for potential oil contamination cleanup and facility remediation costs (considered over the 100year period following the Weeks Island SPR site decommissioning) can be summarized as acceptable to both the DOE SPR Project and the general environmental community. These postclosure risk results and conclusions were the same whether only 10,000 to 30,000 barrels of crude oil (as considered in the $1995 \mathrm{EA}$ ) or up to 1.5 million barrels of oil (as considered in [Molecke et al., 1998]) are abandoned in the Weeks Island SPR facility.

In addition to these potential oil leakage, environmental contamination risks, a single shortterm risk event was also evaluated, the operational risk from (the option of) delaying mine brine fill in order to skim for more oil. This DOE SPR evaluation request was intended to help support SPR Project considerations for continuing or terminating oil skimming operations (as described in Section 5.3). It was based on concerns of observed, accelerated site subsidence that potentially affected the stability of the Weeks Island mine, shafts, and surface facilities (as discussed in Section 4.3). Assessed risk values for this scenario could help the DOE resolve and support decisions to proceed with several decommissioning operational options. These options included continuing forward with then ongoing oil skimming operations to recover more oil, or concluding the skimming operation and resume mine brine filling, to more quickly enhance mine stability.

The risk assessment panel members strongly expressed their concern that the risk of enhanced mine instability, resulting from a partially empty (non brine-filled) mine, was substantial. They did not think the SPR Project should continue with oil skimming, delaying the brine filling. The DOE SPR initiated mitigation actions quickly, restarting mine brine filling operations, basing their decision on both: 1) the "high" calculated risk evaluation (reported to DOE in draft form, shortly after the risk assessment panel meeting in October 1998); and, 2) associated operational concerns, e.g., difficulties in skimming and poor oil recovery cost economics (refer to Section 5.3).

In December 1998, the DOE released a public press statement that up to 1.5 million barrels of crude oil will be left trapped in the salt chamber (former salt mine) at Weeks Island during the site abandonment. The risk assessment study [Molecke et al., 1998] was referenced as the technical basis for the DOE position to abandon further current oil recovery efforts, and continue brine fill of the mine as the better alternative. 


\section{CONCLUSIONS}

The Weeks Island Mine, Iberia Parish, Louisiana, successfully served as a Department of Energy Strategic Petroleum Reserve facility from its conversion from a commercial room and pillar salt mine in 1977, through its closure in late 1999. It stored about 72.5 million bbl of crude oil following oil fill in the 1980-1982 time frame, until late 1995, when the DOE submitted a plan for the decommissioning of the Weeks Island SPR site and initiated oil drawdown procedures. In late 1999, following nearly six years of intense engineering and geotechnical support, the Weeks Island SPR mine and supporting facilities were decommissioned and abandoned by the Department of Energy, without incident.

Site abandonment plans were initiated in 1994, after it was recognized that ground water (non-saturated brine) was leaking into the stored oil chambers by means of a rapidly growing sinkhole that had developed over the southern periphery of the mine. The entire underground oil removal/brine backfill was greatly complicated by the existence of the brine, and the major programmatic concern was that the ground water leak might become uncontrolled before the oil could be systematically removed and the mine backfilled with brine. Construction of a $60-\mathrm{ft}$ diameter freeze wall isolated the primary leak, and the sinkhole growth was successfully controlled by a new saturated brine-injection technique. More than $98 \%$ of the crude oil was finally removed. Based on the final inventory, 1.47 million bbl remain in the mine out of the original 72.5 million bbl. About 1.30 million bbl of the abandoned oil is permanently entrained in the significant quantities of crushed or loose salt remaining within the mine (since its operation as a commercial salt mine). The rest of the abandoned oil is trapped in many small salt roof traps (irregularities) distributed throughout the two levels of the mine. The environmental effects of abandoning 1.47 million bbl of oil in the Weeks Island Mine were quantified with a formal risk assessment study in late 1998 and judged to be environmentally safe (i.e., "no significant environmental impact" in NEPA terminology) and acceptable to both the DOE SPR Project and the general environmental community. Following the oil drawdown process, the Weeks Island Mine was backfilled with saturated brine, in order to accord the greatest degree of geologic stability to the now-abandoned mine. The last permanent personnel at the Weeks Island SPR facility left the site in November 1999.

In July 1999, the DOE SPR Project management Office [Gibson, 1999] sent a letter to the Louisiana Department of Natural resources, Office of Conservation. This letter formally informed the State of Louisiana of the ongoing closure of the Weeks Island facility's oil storage chamber and provided a status of the closure operations. It also advised that almost 1.5 million $\mathrm{bbl}$ of oil was being abandoned, far more than initially envisioned; information was provided on why this situation was unavoidable. The Department's decision to abandon this much oil had been formally communicated to the public in a Press Release dated November 24, 1998. The letter to the State of Louisiana also requested that the Office of Conservation should now proceed to void Conservation Order No. SDS-8 which approved the use of the facility for the storage of oil, effective as of February 16, 1979.

The State of Louisiana, Department of Natural Resources, Office of Conservation acknowledged and agreed [Asprodites, 1999]:

- That the U.S. DOE, its successors or assigns, will continue monitoring the Weeks Island Strategic Petroleum Reserve site as described in its March 1996 decommissioning plan through calendar year 2004. This monitoring includes sampling the ground waters 
to verify containment of the remaining oil, and monitoring the mine subsidence due to salt creep, both to be conducted on a quarterly basis, and anticipated yearly surface inspection walk arounds. Based on the monitoring results, a decision will be made on whether to continue monitoring activities.

- That the U.S. DOE, its successors or assigns, will maintain liability for any future problems that may result from the past storage of crude oil at the former Weeks Island Strategic Petroleum Reserve site in the Weeks Island salt dome.

- The Office of Conservation then ordered, effective on and after September 1, 1999 [Asprodites, 1999]:

- Due to the closure of the upper and lower mine levels of the U.S. DOE Weeks Island Strategic Petroleum Reserve site at the Weeks Island salt dome in Tberia Parish, Conservation Order No. SDS-8 issued and effective February 16, 1979, is hereby terminated.

- The U.S. DOE, its successors or assigns, will submit copies of any monitoring reports obtained from the monitoring program.

- The U.S. DOE will notify the Louisiana Office of Conservation, Injection \& Mining Division of any change in the management or ownership of the former Weeks Island crude oil storage facility.

Appreciation is extended to all personnel and organizations that participated in the successfull operation, engineering, geotechnical guidance, and management of the Weeks Island site and facility over its SPR lifetime, particularly over the period of decommissioning and abandonment, 1994-1999. 


\section{REFERENCES \& Bibliography}

Acres, 1977. Acres American Incorporated, National Strategic Oil Storage Program, Weeks Island Mine - Geotechnical Study. 1977. Report for Gulf Interstate Engineering Company under Contract FEA-125 1-75 to the U. S. Federal Energy Administration (2 volumes).

Acres, 1987. Acres International Corporation, Weeks Island Strategic Petroleum Reserve Geological Site Characterization Report, SAND87-7111. 1987. Sandia National Laboratories, Albuquerque, NM.

Asprodites, 1999. Asprodites, P.N., State of Louisiana, Office of Conservation, Baton Rouge, LA. "Supplement to Order No. SDS-8," Supplemental order terminating Conservation Order No. SDS-8 which approved the use of an existing room and pillar salt mine at the Weeks Island salt dome for the storage of crude oil by the United States Department of Energy Strategic Petroleum Reserve, Iberia Parish, Louisiana. September 3, 1999.

Bauer, S.J. 1998a. Memo to G. Berndsen, DOE SPR, "Recent Observations at Weeks Island Production Shaft," September 20, 1998. Sandia National Laboratories, Albuquerque, NM.

Bauer, S.J. 1998b. Memo to G. Berndsen, DOE SPR, “Quarterly Surface Inspection of Weeks Island Mine Perimeter," September 20, 1998. Sandia National Laboratories, Albuquerque, NM.

Bauer, S.J., 1999a. Subsidence at the Weeks Island SPR Facility, SAND99-0099. January 1999. Sandia National Laboratories, Albuquerque, NM.

Bauer, S.J. 1999b. Memo to G. Berndsen, DOE SPR, "Weeks Island Subsidence Rates 6/9910/99,"November 17, 1999.Sandia National Laboratories, Albuquerque, NM.

Bauer, S.J. and B.L. Ehgartner, 1999. "Subsidence and Its Surface Manifestations at the Weeks Island SPR Facility." Presented at the Solution Mining Research Institute, Fall Meeting, Washington, DC. October 3-6, 1999.

Bauer, S.J. and J.K. Linn, 1998. Memo to G. Berndsen, DOE SPR, "Preliminary Look at Weeks Island Subsidence," September 25, 1998. Sandia National Laboratories, Albuquerque, NM.

Bauer, S.J. and J. Neal, 1997. Memo to G. Berndsen, DOE SPR, “Analysis of Subsidence Data for the Weeks Island Site," March 1997. Sandia National Laboratories, Albuquerque, NM.

Bauer et al., 1994. Bauer, S.J. (editor). Update of Assessment of Geotechnical Risks, Strategic Petroleum Reserve, Weeks Island Site, SAND94-2969. December 1994. Sandia National Laboratories, Albuquerque, NM.

Bauer et al., 1997. Bauer, S.J., B.L. Ehgartner, and J.T. Neal. Geotechnical Studies Associated with Decommissioning the Strategic Petroleum Reserve Facility at Weeks Island, Louisiana: A Case History, SAND97-0974C. June 1997. Presented at 36th U.S. Rock Mechanics Symposium, New York, NY, June 29-July 2, 1997. Sandia National Laboratories, Albuquerque, NM.

Beasley, R.R., et al., 1985. Results of a Geotechnical Risk Assessment Study of the SPR Storage Facility at Weeks Island, Louisiana, SAND 84-2072. 1985. Sandia National Laboratories, Albuquerque, NM. 
Blanford, M.L., D.J. Segalman, and R.L. Parrish, 1990. Strength Analyses of the Weeks Island Bulkheads, SAND90-0013. April 1990. Sandia National Laboratories, Albuquerque, NM.

Capline DEIS, 1977. Draft Capline Environmental Impact Statements. Capline DES 77-9, September 1977.

Capline FEIS, 1978. Final Capline Environmental Impact Statements. Capline DOE/EIS-0024 July 1978. U.S. Department of Energy.

Carney et al., 1995. Carney, K.R., W.J. Autin, E.B. Overton, G. Hunt, and M.A. Molecke. 'Near Surface Gas Mapping Profiles of Salt Geologic Features at the Weeks Island Strategic Petroleum Reserve Site." Presented at the Solution Mining Research Institute, Fall Meeting, San Antonio, Texas, October 1995. Sandia National Laboratories, Albuquerque, NM.

Diamond and Mills, 1994. Diamond, W., Solution Mining Research Institute, and K. E. Mills, DynMcDermott Petroleum Operations. Informal communication at a meeting of SPR program participants and Morton Salt Company personnel. July, 1994.

DOE, 1995a, Strategic Petroleum Reserve Annual/Quarterly Report. Washington, D.C., U.S. Strategic Petroleum Reserve, Report DOE/EE-0055, 15 Feb 95.

DOE, 1995b. Environmental Assessment for Decommissioning the Strategic Petroleum Reserve Weeks Island Facility. DOE/EA- 1051. U.S. Department of Energy. December 1995. Incl.: Finding of No Significant Impact (FONSI) for Decommissioning of the Strategic Petroleum Reserve Weeks Island Facility, W.C. Gibson, SPR Project Manager, December 1, 1995. Incl.: Appendix C, Risk Coding Matrix.

DOE, 1995c. Rousseau, L.J. to W. C. Gibson, Internal Memorandum, "Groundwater Control and Inventory Relocation," March 5, 1995. DOE SPR PMO, New Orleans, LA.

Ehgartner, B.L., 1991. Summary of Characterization Tests on a Low Density Epoxy Grout for Use as a Bulkhead Seal Material in the US Strategic Petroleum Reserve, SAND91-1112. July 1991. Sandia National Laboratories, Albuquerque, NM.

Ehgartner, B. L., 1993. Internal memorandum to J.K. Linn, "Weeks Island Stress Prediction and Relationship to Sinkhole Formation," October 18, 1993. Sandia National Laboratories, Albuquerque, NM.

Ehgartner, B.L., 1999. Internal memorandum to J.K. Linn, "Weeks Island Mechanical Parameters for Estimating Brine Volume." March 25, 1999. Sandia National Laboratories, Albuquerque, NM.

Eldredge, 1999. Eldredge, L., DynMcDermott, personal communication, November 1999.

FEA, 1976. Federal Energy Administration, Strategic Petroleum Reserve Office, Environmental Impact Statement for Weeks Island Mine, DES 76-8, FEA/S-76/349, 1976.

FEA, 1977. Federal Energy Administration, Supplement to Final Environmental Impact Statements for Weeks Island/Cote Blanche Mines. Strategic Petroleum Reserve Office, EPA/7677-7 and FES 76/77-8, FEAS-77/228. 1977.

Gibson, W.C. Jr., 1999. Letter, Department of Energy, Strategic petroleum Reserve Project Management Office, New Orleans, "DOE 99-122: Weeks Island Crude Oil Storage Facility Decommissioning and the Voiding of Conservation Order No. SDS-8," to P.N. Asprodites, 
Office of Conservation, Louisiana Department of Natural Resources, Baton Rouge, Louisiana, July $15,1999$.

Goin, K.L. and J.T. Neal, 1988. Analysis of Surface Subsidence of the Strategic Petroleum Reserve Crude Oil Storage Sites from December 1982 to January 1988, SAND88-1309. June 1988. Sandia National Laboratories, Albuquerque, NM.

Hilton et al., 1979. Hilton, P. D., S. E. Benzley, and M. H. Gubbels. Structural Analysis of Weeks Island Mine/Petroleum Repository, SAND79-0595. 1979. Sandia Laboratories, Albuquerque, NM.

Hinkebein and Linn, 1998. Hinkebein, T. E. and J. K. Linn, Memo to G.B. Berndsen, DOE SPR, "Increase in the Rate of Surface Depression at Sinkhole \#2," September 10, 1998. Sandia Laboratories, Albuquerque, NM.

Hoffman, E.L, 1994a. Internal memorandum to J.K. Linn, "Investigation of Pressurization and Draw Down of the SPR Weeks Island Oil Storage Facility," March 28, 1994. Sandia National Laboratories, Albuquerque, NM.

Hoffman, E.L, 1994b. Stability Evaluation of the Markel Mine at Weeks Island, Louisiana, SAND93-4031, June 1994. Sandia National Laboratories, Albuquerque, NM.

Hoffman, E.L. and B.L. Ehgartner, 1994. Internal memorandum to J. K. Linn, "Performance of the Weeks Island Mine after Decommissioning," December 12, 1994. Sandia National Laboratories, Albuquerque, NM.

Hoffman, E.L. and B.L. Ehgartner, 1996. Three Dimensional Finite Element Simulations of Room and Pillar Mines in Rock Salt, SAND96-0988C. June 1996. Presented at Second North American Rock Mechanics Symposium Montreal, Quebec, June 9-2 1, 1996. Sandia National Laboratories, Albuquerque, NM.

Levin, B.L., 1998a. Internal memorandum to J.K. Linn, "Predicted WI Mine Filled Accumulated Brine Specific Gravity," August 4, 1998. Sandia National Laboratories, Albuquerque, NM.

Levin, B.L., 1998b. Internal memorandum to J. K. Linn, "Brine Flow Monitoring Station Construction Drawings," February 2, 1998. Sandia National Laboratories, Albuquerque, NM:

Levin, B.L., 1999. "Brine Flow Monitoring System Description and Standard Operating Procedure, S0P6113-990504BLL," May 4, 1999. Sandia National Laboratories, Albuquerque, NM.

Linstone, HA. and Turoff, M., eds., 1975. The Delphi Method: Techniques and Applications. Addison-Wesley Publishing Co. Reading, MA.

Magorian, 1998. Williams, C.V., Memo to G.B. Berndsen, Jr. DOE SPR PMO, "Re: T. Magorian's Input on Weeks Island Wet Drift and Other Risks," October 16,1998. Sandia National Laboratories, Albuquerque, NM.

Molecke, M.A., 1997. Memo to G.B. Berndsen, DOE SPRPMO, "Weeks Island SPR: A Review Summary of the Markel Wet Drift and Bulkhead plus Other Isolation Bulkhead Evaluations." June 5, 1997. Sandia National Laboratories, Albuquerque, NM.

Molecke et al., 1996. Molecke, M.A., K.R. Carney, W.J. Autin, and EB. Overton. Near-Surface Gas Mapping Studies of Salt Geologic Features at Weeks Island and Other Sites, SAND96-2502. October 1996. Sandia National Laboratories, Albuquerque, NM. 
Molecke et al., 1998. Molecke, MA., T,E. Hinkebein, S.J. Bauer, and J.K. Linn. Results of the Weeks Island Strategic Petroleum Reserve Oil Leak Risk Assessment Study, SAND982792. December 1998. Sandia National Laboratories, Albuquerque, NM.

Neal, J.T., 1988. Subsidence Monitoring and Evaluation Plan for Strategic Petroleum Reserve Storage Sites, SAND88-1175. August 1988. Sandia National Laboratories, Albuquerque, NM.

Neal, J.T. and R.E. Myers, 1995. Origin, Diagnostics, and Mitigation of a Salt Dissolution Sinkhole at the U,S. Strategic Petroleum Reserve Storage Site, Weeks Island Louisiana, SAND95-0222C. Sandia National Laboratories, Albuquerque, NM. Presented at the Fifth International Symposium on Land Subsidence, The Hague, October 1995. Proceedings of the Fifth International Symposium on Land Subsidence, IAHS Publ. No. 234, 1995.

Neal et al., 1993. Neal, J.T., T.R. Magorian, R.L. Thoms, W.J. Autin, R.P. McCulloh, S. Denzler, K.O. Byrne. Anomalous Zones in Gulf Cost Salt Domes with Special Reference to Big Hill, TX, and Weeks Island, LA. SAND92-2283. 1993. Sandia National Laboratories, Albuquerque, NM.

Neal et al., 1995. Neal, J.T., S.J. Bauer, and B.L. Ehgartner. October 1995. "Sinkhole Progression at the Weeks Island, Louisiana, Strategic Petroleum Reserve (SPR) Site." Presented at the Solution Mining Research Institute, Fall Meeting, San Antonio, Texas, October 1995. Sandia National Laboratories, Albuquerque, NM.

Neal et al., 1996. Neal, J.T. (editor), S.J. Bauer, B.L Ehgartner, J.K. Linn, SE. Lott, T.E. Hinkebein, M.A. Molecke, D.E. Munson, JI. Neal, AR. Sattler, S. Ballard, M.J Bertoldi, RE. Gump, K.E. Mills, D.W. Lamb, S. Thompson, and RE. Myers. Summary of Events and Geotechnical Factors Leading to Decommissioning of the Strategic Petroleum Reserve (SPR) Facility at Weeks Island, Louisiana, SAND96-2263. October 1996. Sandia National Laboratories, Albuquerque, NM.

Neal et al., 1997. Neal, J.T, S. Ballard, S.J. Bauer, B.L. Ehgartner, T.E. Hinkebein, E.L. Hoffman J K Linn MA. Molecke, and A.R. Sattler. Mine-Induced Sinkholes Over the U.S. Strategic Petroleum Reserve (SPR) Storage Facility at Weeks Island, Louisiana: Geologic Mitigation Prior to and During Decommissioning, SAND96-2387A. April 1997. Presented at 6th Multidisciplinary Conference on Sinkholes and the Engineering \& Environmental Impacts of Karst, Springfield, Missouri, April 6-9, 1997. Sandia National Laboratories, Albuquerque, NM.

Neal et al., 1998. Neal, J. T., S. J. Bauer, and B. L. Ehgartner "Mine-induced Sinkholes Over the U. S. Strategic Petroleum Reserve (SPR) Storage Facility at Weeks Island, Louisiana: Geologic Causes and Effects," Land Subsidence Case Studies and Current Research; Proceedings of the Dr. Joseph F. Poland Symposium edited by J. W. Borchers, AEG, Special Publication No. 8, 1998.

O'Hern et al., 1999. O'Hern, T.J., T.E. Hinkebein, and T.W. Grasser. Estimation of Retained Crude Oil Associated With Crushed Salt and Salt Cores in the Presence of Near-Saturated Brine, SAND99-0152. February 1999. Sandia National Laboratories. Albuquerque, NM.

Ortiz, T.S., 1980. Strategic Petroleum Reserve (SPR) Geological Summary Report, Weeks Island Salt Dome, SAND80-1323, 1980. Sandia National Laboratories. Albuquerque, NM. 
PB-KBB, 1996. "Plugging and Abandonment Plan for the Weeks Island Strategic Petroleum Reserve Facility." Report to U.S. DOE, Mine Integrity Management Group, New Orleans, LA. 1996.

Preece, D.S., 1987. 3-D Finite Element Calculation of Subsidence Induced Deformation of the Weeks Island Service Shaft, SAND87-2365. December 1987. Sandia National Laboratories, Albuquerque, NM.

Preece, D.S. and R.D. Krieg, 1984. Finite Element Study of Working Level Separation at the Weeks Island Salt Dome, SAND84-1021. July 1984.Sandia National Laboratories, Albuquerque, NM.

Preece, D.S. and B.L. Ehgartner, June 1994. Structural Stability of the Weeks Island Oil Repository, SAND94-1026. June 1994. Sandia National Laboratories, Albuquerque, NM.

Sattler, A.R., 1996. Log Analysis of Six Boreholes in Conjunction with Geologic Characterization Above and On Top of the Weeks Island Salt Dome, SAND96-0413. June 1996. Presented at the Solution Mining Research Institute, 1996 Spring Meeting, Houston, Texas. Sandia National Laboratories, Albuquerque, NM.

Sattler et al., 1996. Sattler, AR., R.S. Harding, R.D. Jacobson, J.T. Finger, R. Keefe, and IT. Neal. Characterizing the Weeks Island Salt Drilling of and Seismic Measurements from Dome Boreholes, SAND96-1884C. September 1996. Presented at the Solution Mining Research Institute, 1996 Fall Meeting, Cleveland, Ohio. Sandia National Laboratories, Albuquerque, NM.

Van Sambeek et al., 1994. Van Sambeek, L. L., J.D. Osnes, and J.D. Nieland. Geomechanics Considerations for Flooding the Weeks Island Mine Strategic Petroleum Reserve Facility. Topical Report RSI-0541, September 1994. RE/SPEC Inc., Rapid City, SD.

Walk, Haydel and Associates, 1996. "Weeks Island Oil Skimming System - Subsurface Facility." AFC Submittal under Contract No. DE-AC96-94P0 19002, with U. S. DOE.

Walk, Haydel and Associates, 1998. "PB-KBB Engineering, Construction, Operations, Weeks Island Surface/Subsurface Decommissioning Drawings and Specifications," Contract No. DE-AC96-94PO19002, SCN 50820-17, Task No. WI-OM-159, September 1998, New Orleans, LA.

Walk, Haydel and Associates, 1999. "PB-KBB Engineering, Construction, Operations, Weeks Island Surface/Subsurface Decommissioning Drawings and Specifications," Contract No. DE-AC96-94P0 19002, SCN Number 50820-28. Task No. WI-OM-159," May 1999. New Orleans, LA.

Williams, C.V., 1997. Memo to G.B. Berndsen, DOE SPR PMO, "Re: June 1997 Markel Mine Inspection Report." June 1, 1997. Sandia National Laboratories, Albuquerque, NM. 


\section{DISTRIBUTION}

U.S. DOE SPR PMO (13)

900 Commerce Road East

New Orleans, LA 70123

Attn: W.C. Gibson, FE-44

G.B. Berndsen, FE-443.1 (5)

D. Brine, FE-443.1

J. C. Kilroy, FE 443

R.E. Myers, FE-4421

J. Culbert, FE-443

N. Shourbaji, FE 4421

TDCS (2)

U.S. Department of Energy (4)

Strategic Petroleum Reserve

1000 Independence Avenue SW

Washington, D.C. 20585

Attn: $\quad$ R. Furiga, FE-40

D. Johnson, FE-421

D. Buck, FE-421

H. Giles, FE-423

DynMcDermott (5)

850 South Clearview Parkway

New Orleans, LA 70123

Attn: Steve Ball,

L. Eldredge, DM-30

K.E. Mills, DM-25

J. McHenry, DM-21

T. Westbrook, DM-83

PB-KBB Inc. (3)

11767 Katy Freeway

P.O. Box 19672

Houston, TX 77224

Attn: S. Raghuraman (2)

K. Stayer

Acres International Corporation 140 John James Audubon Parkway

Amherst, NY 14228-1180

Attn: S.N. Thompson

T.R. Magorian

133 South Drive

Amherst, NY 14226-4119

\author{
J. T. Neal \\ 1911 Crestview dr. \\ Prescott, AZ 86305
}

Sandia Internal: (34)

MS 0701 P.B. Davies, 6100

MS 0431 S.G. Varnado, 6200

MS 0706 J.K. Linn, 6113 (10)

MS 0706 S.J. Bauer, 6113

MS 0706 T.E. Hinkebein, 6113

MS 0706 M.A. Molecke, 6113 (10)

MS 0706 B.L. Ehgartner, 6113

MS 0706 B.L. Levin, 6113

MS 0706 D.E. Munson, 6113

MS 0705 A.R. Sattler, 6113

MS 0750 S. Ballard, 6116

MS 0734 C.V. Williams, 6803

MS 9018 Central Tech. Files, 8940-2

MS 0899 Technical Library, 4916 (2)

MS 0612 Review and Approval Desk for DOE/OSTI, 4912 